\title{
Small bioactive peptides for biomaterials design and therapeutics
}

Article

Accepted Version

Hamley, I. W. (2017) Small bioactive peptides for biomaterials design and therapeutics. Chemical Reviews, 117 (24). pp. 14015-14041. ISSN 1520-6890 doi:

https://doi.org/10.1021/acs.chemrev.7b00522 Available at https://centaur.reading.ac.uk/74704/

It is advisable to refer to the publisher's version if you intend to cite from the work. See Guidance on citing.

To link to this article DOI: http://dx.doi.org/10.1021/acs.chemrev.7b00522

Publisher: American Chemical Society

All outputs in CentAUR are protected by Intellectual Property Rights law, including copyright law. Copyright and IPR is retained by the creators or other copyright holders. Terms and conditions for use of this material are defined in the End User Agreement.

\section{www.reading.ac.uk/centaur}

\section{CentAUR}

Central Archive at the University of Reading

Reading's research outputs online 
Small Bioactive Peptides for Biomaterials Design and Therapeutics

\author{
I.W.Hamley \\ Dept of Chemistry, University of Reading, Whiteknights, Reading RG6 6AD, U.K. \\ I.W.Hamley@reading.ac.uk
}




\begin{abstract}
This review aims to provide a concise yet extensive survey of key short bioactive peptide sequences for a range of applications ranging from biomaterials development through to peptides with therapeutic uses. The following are considered: cell adhesion motifs, structural peptides, cell-penetrating and tumor-homing peptides, antimicrobial peptides, peptide hormones, growth factors and matrix metalloprotease substrates, neuropeptides, amyloid peptides, antioxidant peptides, peptide affinity tags, anticancer peptides and others. This review provides a convenient resource, summarizing a broad range of important sequences with great utility both as a resource concerning small peptide drugs and also novel biofunctional peptide-based materials.
\end{abstract}




\section{Table of Contents}

1. Introduction

2. Cell adhesion peptides

3. Structural Peptides

4. Cell-Penetrating and Tumor-Homing Peptides

5. Antimicrobial Peptides

6. Peptide Hormones

7. Tissue Engineering and Biomaterials Development

8. Amyloid Peptides

9. Neuropeptides, Antioxidants and Immune-Related Peptides

10. Protein Tags

11. Anti-Cancer Peptides

12. Miscellaneous Peptides

13. Conclusions and Discussion 


\section{Introduction}

Peptides are remarkable biomolecules with a huge diversity of important roles in vivo. Short peptides are generally easy to synthesize by chemical routes or they can be obtained recombinantly and are thus attractive agents and targets for therapies and diagnostics and the fabrication of bionanomaterials. This review provides a summary of short bioactive peptide sequences as a useful "one-stop" reference. Since it is obviously not possible to discuss every short peptide sequence with bioactivity that has been discovered or synthesized, the focus here is on key sequences. This means sequences that have been used in research by many groups for a specific application. Most peptides considered in this review are the subject of papers with a few dozen citations, although newer key works providing important insights are also discussed. Peptides with a broad range of activities ranging from cell adhesion motifs to model amyloid peptides are considered here, but it is not possible to list every single short peptide sequence that has been studied, hence a threshold has been applied.

This review only deals with short bioactive peptides, short here referring to a peptide with approximately 18 or fewer residues. This is a somewhat arbitrary cut-off in some senses but it does correspond roughly to the length of peptide that might be considered for routine solid phase synthesis. In addition, it ensures that this review itself is reasonably compact. Longer peptides such as the peptide hormones glucagon (29 residues) or insulin (human insulin has 51 residues) are not discussed here. As a general comment, it may be noted that short native linear peptides with ca. 20-100 residues tend to adopt $\alpha$-helical structures. A linear peptide must have at least a 
couple of heptad repeats to form an $\alpha$-helical structure. In contrast, many (but by no means all) shorter peptide fragments can form $\beta$-sheet structures (or can be designed to do so), as discussed below. Also longer peptides with suitable repetitive domains can form $\beta$-sheet or other secondary structures (polyproline II for example, in the case of collagen). Cyclic peptides due to steric constraints tend to adopt turn structures.

This review covers short peptides with bioactivities as summarized in Fig.1. These include peptides with roles as cell adhesion motifs, structural peptides (typically sequences from extracellular matrix proteins), cell-penetrating and tumor-homing peptides, antimicrobial peptides, peptide hormones, growth factors and matrix metalloprotease substrates, amyloid peptides, neuropeptides, and other miscellaneous natural peptides and peptide tags. The peptides have been discovered through a variety of methods which include isolation from natural products, rational screening methods such as phage display or peptide library methods or $a b$ initio design or "bioinspired" design. Recently, high throughput screening based on protein database analysis has been shown to have great scope in the identification of key sequences, for example for binding domains to particular substrates.

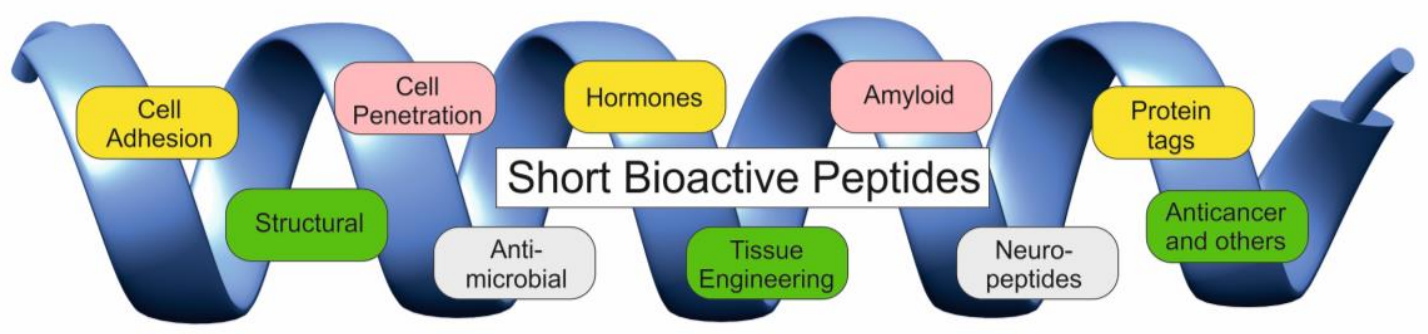

Fig.1. Classes of bioactive peptide considered in this review. 
There is overlap between some sections, in one example antimicrobial peptides often show cell-penetrating properties. In another case, combinations of peptides with different functionalities may be required for a specific application. For example, tissue engineering and the development of protein/peptide-based biomaterials requires the presence of multiple motifs, including cell adhesion sequences but also structural domains, degradation domains, growth-factor stimulating motifs and others. Excellent reviews cover some of the required peptide sequences for biomaterials application in tissue engineering, wound healing and regenerative medicine. ${ }^{1-3}$ Integrin cell adhesion motifs such as the classic RGD sequence have been reviewed. ${ }^{4}$ Reviews are also available on cell-penetrating peptides, ${ }^{5-6}$ antimicrobial peptides ${ }^{7-12}$ (note though that many animal-derived peptides have sequences too long to be considered here ${ }^{13-14}$ ), peptide hormones, ${ }^{15-19}$ amyloid,${ }^{20-28}$ neuropeptides, ${ }^{29-32}$ protein tags,${ }^{33-37}$ and miscellaneous peptides including those with anti-cancer activity. To the best of our knowledge, there are no reviews providing a compact and up-to-date brief summary of bioactive short peptides. A recent review covers orally absorbed cyclic peptides. ${ }^{38}$ Inevitably for such a broad topic, there will be omissions for which we apologize in advance. This review is a survey of important and widely-used small bioactive peptides, covering the literature from the initial reports on the discovery or design of these peptides up to recent examples of their applications. It is not intended to discuss every single newly synthesized or discovered small peptide in a review with the scope of this one. The intention is to provide a timely and useful summary, providing a "toolbox" of known bioactive short peptides for researchers developing new biomaterials. 
In the following, peptide sequences are presented with single letter codes. D-amino acids are generally indicated with lower case letters. Peptide termini are generally not specified.

Table 1. Summary of Short Bioactive Peptides

\begin{tabular}{|c|c|c|c|}
\hline Sequence/Name & Source & Activity & Key references \\
\hline $\mathrm{RGD}(\mathrm{S})$ & Fibronectin & $\begin{array}{l}\text { Integrin cell } \\
\text { adhesion motif }\end{array}$ & $4,39-44$ \\
\hline Eptifibatide & $\begin{array}{l}\text { Derived from a } \\
\text { snake venom } \\
\text { peptide }\end{array}$ & $\begin{array}{l}\text { Integrin cell } \\
\text { adhesion motif } \\
\text { and } \\
\text { antithrmobyltic }\end{array}$ & \begin{tabular}{|l|}
$45-47$ \\
\end{tabular} \\
\hline PHSRN & Fibronectin & Synergy domain & 48 \\
\hline REDV & Fibronectin & $\begin{array}{l}\text { Integrin cell } \\
\text { adhesion motif }\end{array}$ & \begin{tabular}{|l|}
$49-50$ \\
\end{tabular} \\
\hline YIGSR & Laminin & $\begin{array}{l}\text { Integrin cell } \\
\text { adhesion motif }\end{array}$ & $51-52$ \\
\hline IKVAV & Laminin & $\begin{array}{l}\text { Integrin cell } \\
\text { adhesion motif }\end{array}$ & 53 \\
\hline DGEA & Collagen (type I) & $\begin{array}{l}\text { Integrin cell } \\
\text { adhesion motif }\end{array}$ & 54 \\
\hline KRSR & $\begin{array}{l}\text { Designed based } \\
\text { on consensus } \\
\text { repeat }\end{array}$ & $\begin{array}{l}\text { Heparin binding } \\
\text { and osteoblast } \\
\text { adhesion }\end{array}$ & $55-57$ \\
\hline GFOGER/GFPGER & $\begin{array}{l}\text { Collagen (type I } \\
\text { and type IV) }\end{array}$ & $\begin{array}{l}\text { Integrin cell } \\
\text { adhesion motif }\end{array}$ & \begin{tabular}{|l|}
$58-61$ \\
\end{tabular} \\
\hline$(G A G A)_{n}$ & Silk & Structural protein & 62 \\
\hline $\begin{array}{l}(\mathrm{GXY})_{\mathrm{n}}(\mathrm{X}, \mathrm{Y}=\text { residues } \\
\text { other than } \mathrm{G}, \text { typically } \mathrm{P} \text { or } \\
\mathrm{O} \text {, hydroxyproline })\end{array}$ & Collagen & Structural protein & $63-65$ \\
\hline$(\mathrm{VPGXG})_{\mathrm{n}}$ & Elastin & Structural protein & $66-67$ \\
\hline GGRPSDSYGAPGGGN & Resilin & Structural protein & $68-70$ \\
\hline GYSGGRPGGQDLG & Resilin & Structural protein & $70-71$ \\
\hline $\begin{array}{l}\text { YGRKKRRQRRR (TAT } \\
\text { peptide) }\end{array}$ & $\begin{array}{l}\text { HIV regulatory } \\
\text { protein }\end{array}$ & $\begin{array}{l}\text { Cell-penetrating } \\
\text { peptide }\end{array}$ & \begin{tabular}{|l}
$72-78$ \\
\end{tabular} \\
\hline Penetratin & $\begin{array}{l}\text { Drosophila } \\
\text { development } \\
\text { DNA-binding } \\
\text { protein }\end{array}$ & $\begin{array}{l}\text { Cell-penetrating } \\
\text { peptide }\end{array}$ & \begin{tabular}{|l|}
$79-81$ \\
\end{tabular} \\
\hline RRWWRF & Designed & AMP & 82 \\
\hline Surfactin & Bacteria & AMP & $83-85$ \\
\hline Bacitracin & Bacteria & AMP & $86-89$ \\
\hline Polymyxins & Bacteria & AMPs & $90-91$ \\
\hline
\end{tabular}




\begin{tabular}{|c|c|c|c|}
\hline Tachyplesins & Horseshoe crab & AMPs & $7,13,92$ \\
\hline Protegrins & $\begin{array}{l}\text { Porcine } \\
\text { leukocytes }\end{array}$ & AMPs & $13,93-94$ \\
\hline Defensins & $\begin{array}{l}\text { Various } \\
\text { vertebrates and } \\
\text { invertebrates }\end{array}$ & AMPs & $7-8,13,94-96$ \\
\hline Bactenecin & $\begin{array}{l}\text { Bovine } \\
\text { neutrophils }\end{array}$ & AMP & 97 \\
\hline Indolicidin & $\begin{array}{l}\text { Bovine } \\
\text { neutrophils }\end{array}$ & AMP & $7,11,13,98$ \\
\hline Daptomycin & Bacteria & AMP & 99-101 \\
\hline LPFFD & Designed & $\begin{array}{l}\text { Amyloid } \beta \text { fibril } \\
\text { disruptor }\end{array}$ & 102 \\
\hline Oxytocin & Natural hormone & $\begin{array}{l}\text { Activities related } \\
\text { to childbirth and } \\
\text { social bonding }\end{array}$ & 63,103 \\
\hline Vasopressins & $\begin{array}{l}\text { Natural } \\
\text { hormones }\end{array}$ & $\begin{array}{l}\text { Water retention } \\
\text { Vasoconstriction }\end{array}$ & 103 \\
\hline Angiotensins & $\begin{array}{l}\text { Natural } \\
\text { hormones }\end{array}$ & Vasoconstriction & 103-105 \\
\hline Bradykinin & Natural hormone & Vasodilator & $106-108$ \\
\hline pGHWSYGLRPG & Natural hormone & $\begin{array}{l}\text { Stimulates } \\
\text { hormone release }\end{array}$ & 109 \\
\hline PWpG & Natural hormone & $\begin{array}{l}\text { Stimulates } \\
\text { hormone release }\end{array}$ & $110-113$ \\
\hline Somatostatin & Natural hormone & $\begin{array}{l}\text { Endocrine system } \\
\text { regulator (growth } \\
\text { hormone } \\
\text { inhibitor), } \\
\text { neurotransmitter }\end{array}$ & 114 \\
\hline Octreotide & $\begin{array}{l}\text { Somatostatin } \\
\text { analogue }\end{array}$ & $\begin{array}{l}\text { Growth hormone } \\
\text { inhibitor and } \\
\text { glucagon and } \\
\text { insulin inhibitor }\end{array}$ & $115-116$ \\
\hline Lanreotide & $\begin{array}{l}\text { Somatostatin } \\
\text { analogue }\end{array}$ & $\begin{array}{l}\text { Growth hormone } \\
\text { inhibitor and } \\
\text { glucagon and } \\
\text { insulin inhibitor }\end{array}$ & $117-119$ \\
\hline $\begin{array}{l}\text { Luteinizing hormone } \\
\text { releasing hormone }\end{array}$ & Natural hormone & $\begin{array}{l}\text { Sperm and } \\
\text { testosterone } \\
\text { production }\end{array}$ & 109,114 \\
\hline WMNF & Natural hormone & Anxiolytic & 120 \\
\hline GNNQQNY & $\begin{array}{l}\text { Yeast prion } \\
\text { protein }\end{array}$ & $\begin{array}{l}\text { Model Amyloid } \\
\text { Peptide }\end{array}$ & $121-122$ \\
\hline VQIVYK & Tau protein & $\begin{array}{l}\text { Model Amyloid } \\
\text { Peptide }\end{array}$ & $123-125$ \\
\hline$(\text { AEAEAKAK })_{2}$ & $\begin{array}{l}\text { DNA-binding } \\
\text { protein zuotin }\end{array}$ & Model Amyloid & 126 \\
\hline RADARADARADARADA & Designed & Tissue & $127-129$ \\
\hline
\end{tabular}




\begin{tabular}{|c|c|c|c|}
\hline & $\begin{array}{l}\text { alternating } \\
\text { peptide }\end{array}$ & engineering & \\
\hline FF & Dipeptide & $\begin{array}{l}\text { Simplified } \\
\text { peptide } \\
\text { nanostructure } \\
\text { former }\end{array}$ & 130 \\
\hline GPQGIAG & Collagen type I & MMP substrate & 131-132 \\
\hline Enkephalins & $\begin{array}{l}\text { Natural opioid } \\
\text { receptor } \\
\text { peptides }\end{array}$ & $\begin{array}{l}\text { Opioid receptor } \\
\text { peptides. } \\
\text { Neurotransmitters }\end{array}$ & 103,133 \\
\hline Endomorphins & $\begin{array}{l}\text { Natural opioid } \\
\text { receptor } \\
\text { peptides }\end{array}$ & $\begin{array}{l}\text { Opiod receptor } \\
\text { peptides. }\end{array}$ & $134-135$ \\
\hline Substance P & Neurotransmitter & $\begin{array}{l}\text { Neurotransmitter } \\
\text { and other roles }\end{array}$ & 136 \\
\hline Dalargin & $\begin{array}{l}\text { Leu-enkephalin } \\
\text { analogue }\end{array}$ & $\begin{array}{l}\text { Opioid receptor } \\
\text { agonist }\end{array}$ & 137 \\
\hline Glutathione & $\begin{array}{l}\text { Natural in most } \\
\text { organisms }\end{array}$ & Antioxidant & 138 \\
\hline$\beta \mathrm{AH}$ (carnosine) & $\begin{array}{l}\text { Muscle and } \\
\text { brain tissue }\end{array}$ & Antioxidant & $76,139-140$ \\
\hline Cyclosporin & Soil fungus & $\begin{array}{l}\text { Immune } \\
\text { supressant }\end{array}$ & $141-143$ \\
\hline Oligo(arginine) & $\begin{array}{l}\text { Synthetic, } \\
\text { recombinant }\end{array}$ & $\begin{array}{l}\text { Protein fusion tag } \\
\text { (also cell- } \\
\text { penetrating and } \\
\text { antimicrobial) }\end{array}$ & 34,144 \\
\hline Oligo(histidine) & $\begin{array}{l}\text { Synthetic, } \\
\text { recombinant }\end{array}$ & Protein fusion tag & $145-146$ \\
\hline WSHPQFEK (StrepTag II) & $\begin{array}{l}\text { Synthetic, } \\
\text { recombinant }\end{array}$ & Protein fusion tag & $34,147-148$ \\
\hline EQKLISEEDL (myc tag) & $\begin{array}{l}\text { Synthetic, } \\
\text { recombinant }\end{array}$ & Protein fusion tag & 34,149 \\
\hline DYKDDDDK (FlagTag) & Designed & Protein fusion tag & 33,150 \\
\hline Bleomycins & Bacteria & $\begin{array}{l}\text { Anti-cancer } \\
\text { activity }\end{array}$ & $151-155$ \\
\hline Dolastatin 10 & $\begin{array}{l}\text { Marine } \\
\text { organism }\end{array}$ & $\begin{array}{l}\text { Anti-cancer } \\
\text { activity }\end{array}$ & $156-157$ \\
\hline Apicidin & $\begin{array}{l}\text { Fungal } \\
\text { metabolite }\end{array}$ & $\begin{array}{l}\text { Anti-cancer } \\
\text { activity }\end{array}$ & $158-160$ \\
\hline Romidepsin & Soil bacterium & $\begin{array}{l}\text { Anti-cancer } \\
\text { activity }\end{array}$ & $161-166$ \\
\hline Largazole & Cyanobacterium & $\begin{array}{l}\text { Anti-cancer } \\
\text { activity }\end{array}$ & $167-168$ \\
\hline Aspartame (DF-OMe) & Synthetic & $\begin{array}{l}\text { Artificial } \\
\text { sweetener }\end{array}$ & $169-170$ \\
\hline
\end{tabular}


AMP denotes antimicrobial peptide, $\mathrm{pG}$ denotes the non-canonical residue pyroglutamic acid (Fig.13b).

\section{Cell Adhesion Peptides}

The RGD peptide is the minimal unit of a cell adhesive activity domain present in adhesion proteins such as fibronectin, fibrinogen and vitronectin, which all contain integrin ligands. ${ }^{41,39-44}$ RGD is also presented as an adhesion recognition sequence in other proteins including laminin and some types of collagen. ${ }^{171}$ It is used as a canonical cell adhesion motif in a vast range of biomaterials research, interacting with the $\alpha_{v} \beta_{3}$ and $\alpha_{v} \beta_{5}$ receptors, and was originally identified as a key factor in angiogenesis. The tetrapeptide RGDS, which is also located at the tenth type III repeating domain of fibronectin, exhibits high cell adhesion activity via binding to the integrin cell-surface receptors. ${ }^{40,43-44,172}$ This motif is, like the shorter RGD variant, widely used to encourage cell growth in synthetic biomaterials. ${ }^{173-178}$ The tetrapeptide sequence and more especially the tripeptide RGD subunit are widely employed in the development of bionanomaterials for applications in cell growth/differentiation or tissue scaffolding. ${ }^{179}$ The RGDS tetrapeptide has antithrombolytic activity due to the inhibition of platelet aggregation resulting from the fibrinogen recognition sequence. ${ }^{180-181}$ The bioactive RGD and RGDS motifs have also been incorporated into peptide amphiphiles (PAs). ${ }^{175,}$ 177, ${ }^{182-187}$ The RGDS tetrapeptide may have enhanced bioactivity compared to RGD due to the additional serine residue. ${ }^{40,188-191}$ The self-assembly of materials containing RGD-peptide sequences has been reviewed elsewhere. ${ }^{191}$ Consideration has been given to why RGD is an effective cell adhesion motif, for instance whether the charge pattern anionic R and cationic D separated by neutral glycine residue). However, the properties of arginine (such as its ability to 
form bidentate hydrogen bonds with carboxylic acids (Fig.4) seem vital since the analogous KGD sequence is known as a "disintegrin" sequence, for example it is found in some snake venom peptide sequences, ${ }^{192-193}$ instead of RGD which is a potent integrin receptor blocker. KGD is a more specific receptor antagonist. ${ }^{192-193}$ Disintegrins are short proteins with activity as inhibitors of both platelet adhesion and integrin-binding, however the sequences are too long for this class of protein to be considered in this review. Actually, covalent attachment of the residues may not be essential. For example, it has been shown that co-assembly of Fmoc-dipeptides [Fmoc: fluorenylmethyloxycarbonyl] that display R and D separately, i.e. Fmoc-3F-FR and Fmoc-3F-FD [3F-F denotes triply fluorinated phenylalanine], leads to a fibril structure which is cytocompatible. ${ }^{194}$

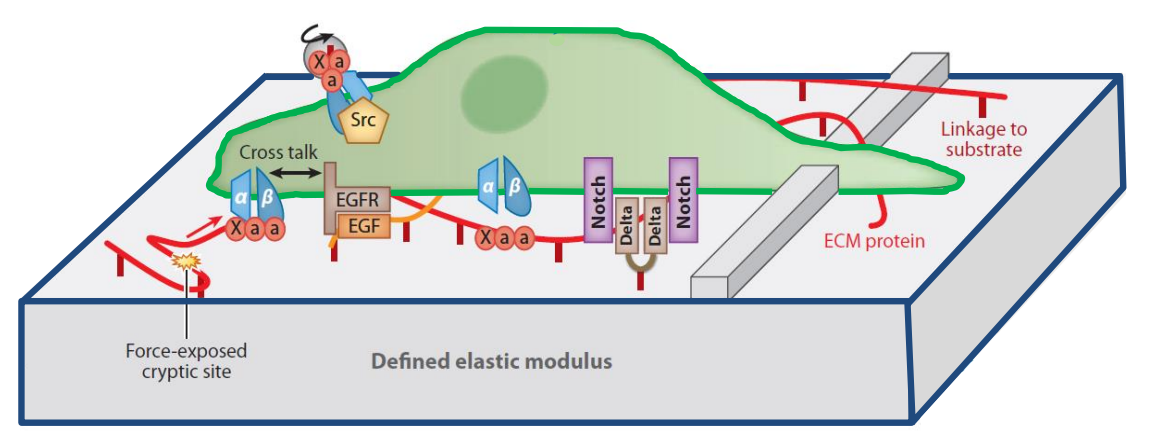

Fig.2 There are multiple cues for cell adhesion with the extracellular matrix. Adapted with permission from Ref. ${ }^{195}$ Copyright 2010 Annual Reviews. These include integrins (labelled $\alpha, \beta$ ), cell adhesion motifs Xaa (e.g. RGD), growth factors and their receptors (e.g. epidermal growth factor receptor, EGFR) and Notch transmembrane cell signaling receptors. Delta is a morphogenic biochemical factor involved in ligand clustering. Src is a mechanotransductive tyrosine kinase associated with focal adhesions.

Cyclic RGD peptides such as cyclo(RGDfV) (f: D-phenylalanine) are known to have superior activity and selectivity compared to linear analogues. ${ }^{196-197}$ This peptide was identified through competitive $\alpha_{v} \beta_{3}$ integrin cell adhesion inhibition studies. ${ }^{196}$ The 
cyclic $N$-methylated compound cyclo(RGDf[N-Me $] \mathrm{V})$ with trade name cilengitide is under investigation for the treatment of the brain cancer glioblastoma. ${ }^{17,197-199}$ The related cyclic heptapeptide eptifibatide (also known as integrilin) also contains an RGD mimetic sequence Mpr-HomoArg-GDWPC-NH2 (cyclized via disulfide bridge) [Mpr: mercaptopropionic acid, HomoArg: homoarginine] ${ }^{47}$ It is an important antithrombolytic agent as it inhibits platelet aggregation. ${ }^{46}$ It was derived based on a sequence from a snake venom peptide. ${ }^{45,47}$

It is known that high affinity recognition by the $\alpha_{5} \beta_{1}$ integrin requires a so-called synergy peptide PHSRN, a sequence present in fibronectin. ${ }^{48,200-201}$ However, it has been noted that mixing (equimolar quantities of) peptide amphiphiles presenting PHSRN and GRGDSP does not lead to significant synergistic effects on $\alpha_{5} \beta_{1}$ recognition. ${ }^{202-203}$ Instead, careful design of a peptide to present these sequences in a similar fashion to fibronectin is required (i.e. the spacing between the ligands and nature of the spacer need to be considered). ${ }^{202-204}$

The REDV (and lesser known LDV) sequences are also cell adhesion motifs from fibronectin. They bind to the $\alpha_{4} \beta_{1}$ integrin. ${ }^{49-50}$ REDV sequence bears obvious sequence similarity to RGDS. It was noted that endothelial cells such as HUVECs (human umbilical vein endothelial cells) adhere to an REDV functionalized substrate but not fibroblasts or vascular smooth muscle cells. ${ }^{205-206}$ The KQAGDV sequence also promotes smooth muscle cell adhesion. ${ }^{55,207-208}$ 
The YIGSR peptide is a cell adhesion domain from the extracellular matrix protein laminin, present in the basement membrane. ${ }^{51-52}$ Both poly(RGD) and poly(YIGSR) have been reported to show anticancer activity, which is enhanced compared to the corresponding oligomers, against lung tumors in mice. ${ }^{209}$ Multimeric YIGSR also inhibits angiogenesis and tumor growth of human fibrosarcoma cells in mice. ${ }^{210}$ The IKVAV peptide, also obtained from laminin, promotes cell attachment, spreading and neurite outgrowth. ${ }^{53}$ A peptide amphiphile (PA) incorporating IKVAV shows promise in the treatment of spinal cord injuries in a study where cultured cells such as neurons were exposed to solutions containing PA fibrils. ${ }^{211-212}$ A hybrid PA incorporating both laminin sequences YIGSR and IKVAV supports the survival of neurons and their morphogenesis (dendrite and axon growth) when mixed with collagen to form a fibrous scaffold. ${ }^{213}$ Other laminin cell adhesion recognition sequences such as PDSGR (a synergy peptide for YIGSR) have been identified ${ }^{171,200,214}$ but are less widely employed.

A minimal sequence DGEA from type I collagen is able to recognize the $\alpha_{2} \beta_{1}$ integrin receptor. ${ }^{54}$ Peptides containing this sequence are able to inhibit adhesion of platelets to collagen mediated by $\alpha_{2} \beta_{1}$, but not $\alpha_{\mathrm{v}} \beta_{1}$-mediated adhesion of platelets to fibronectin or $\alpha_{6} \beta_{1}$-mediated adhesion to laminin. ${ }^{54}$ For breast adenocarcinoma cells which use $\alpha_{2} \beta_{1}$ as a collagen/laminin receptor, adhesion of collagen and laminin was inhibited by DGEA-containing peptides. Stem cell (human mesenchymal stem cells, hMSC) attachment was compared ${ }^{215}$ for coatings of PAs incorporating three different cell adhesion motifs - RGDS, DGEA and KRSR. The RGDS-containing PA showed the highest initial attachment and subsequent osteogenic differentiation. ${ }^{215}$ The latter is a heparin proteoglycan binding sequence and osteoblast adhesion promotor. ${ }^{55-57}$ 
The KRSR motif was discovered as a consensus repeat from protein database analysis of bone-related adhesion proteins. ${ }^{57}$

The GFOGER (O: hydroxylproline) domain, originally identified based on the sequence GFPGER within collagen $\mathrm{I},{ }^{61}$ is a high affinity binding site to the integrin $\alpha_{2} \beta_{1}$ in collagens I and IV and $\alpha_{1} \beta_{1}$ in collagen $1 .{ }^{60}$ Integrin binding sites to other collagens have also been identified. ${ }^{59}$ Since the $\alpha_{2} \beta_{1}$ integrin receptor is involved in osteogenesis, the GFOGER domain has been incorporated into biomaterials designed to assist bone repair. ${ }^{216-217}$

\section{Structural Peptides}

Structural peptides can be large molecules, however they are included in this review since they comprise repeated short peptide sequences. One very widely studied structural peptide is silk. Silk has a semicrystalline structure with crystalline domains embedded in an amorphous matrix. ${ }^{62}$ Silk from the Bombyx mori silk moth can be considered to be a multiblock copolymer. The crystalline domains contain repetitive $(\text { GAGA })_{\mathrm{n}}$ domains forming stacked $\beta$-sheets as well as GS and GT hydroxylcontaining dipeptide sequences. ${ }^{62,218-219}$ On the other hand, dragline spider silk contains polyalanine repeats..$^{62,220}$

Collagen is another structural protein based on repetitive peptide sequences. Collagen chains form a right-handed triple helical structure. The peptide contains repeating GXY triplets where $\mathrm{X}$ and $\mathrm{Y}$ are often proline and hydroxyproline respectively. ${ }^{63-65}$ Elastin is an important extracellular matrix protein with, as its name suggests, elastic properties. It is an essential constituent of connective tissues such as skin and 
ligament. Elastin-like peptides (ELPs) contain (VPGXG) $)_{\mathrm{n}}$ repeats where $\mathrm{X}$ can be any amino acid except proline. ${ }^{67,221}$ ELPs have attracted great interest since they undergo a transition resembling a lower critical solution temperature (LCST), above which the polymer chains collapse and phase separation from water occurs. ${ }^{221-222}$ This can be exploited in thermoresponsive release systems for example. ${ }^{223}$

Resilin is a structural protein found in insect wings, ligaments and other insect and arthropod organs. It has elastic properties. Bioactive sequences from the full peptide have been identified and used to create elastomeric biomaterials. ${ }^{69}$ The first key resilin sequence identified was GGRPSDSYGAPGGGN, this being presented in repetitive form at the $\mathrm{N}$ terminus of a protein express by Drosophila melanogaster. ${ }^{68-}$ ${ }^{70}$ Another key sequence is GYSGGRPGGQDLG ${ }^{70-71}$ and others are listed in the literature. ${ }^{70}$ These sequences are essential in conferring elasticity. The tyrosine residues in resilin can undergo cross-linking (through radical formation) which has a significant impact on its structural and mechanical properties..$^{224-225}$

\section{Cell-Penetrating and Tumor-Homing Peptides}

There are a number of mechanisms by which cell-penetrating peptides can enter cells as illustrated in Fig.3 involving direct translocation or via various endocytosis

processes. This subject is reviewed extensively elsewhere. -6, 226-229 $^{-29}$ 


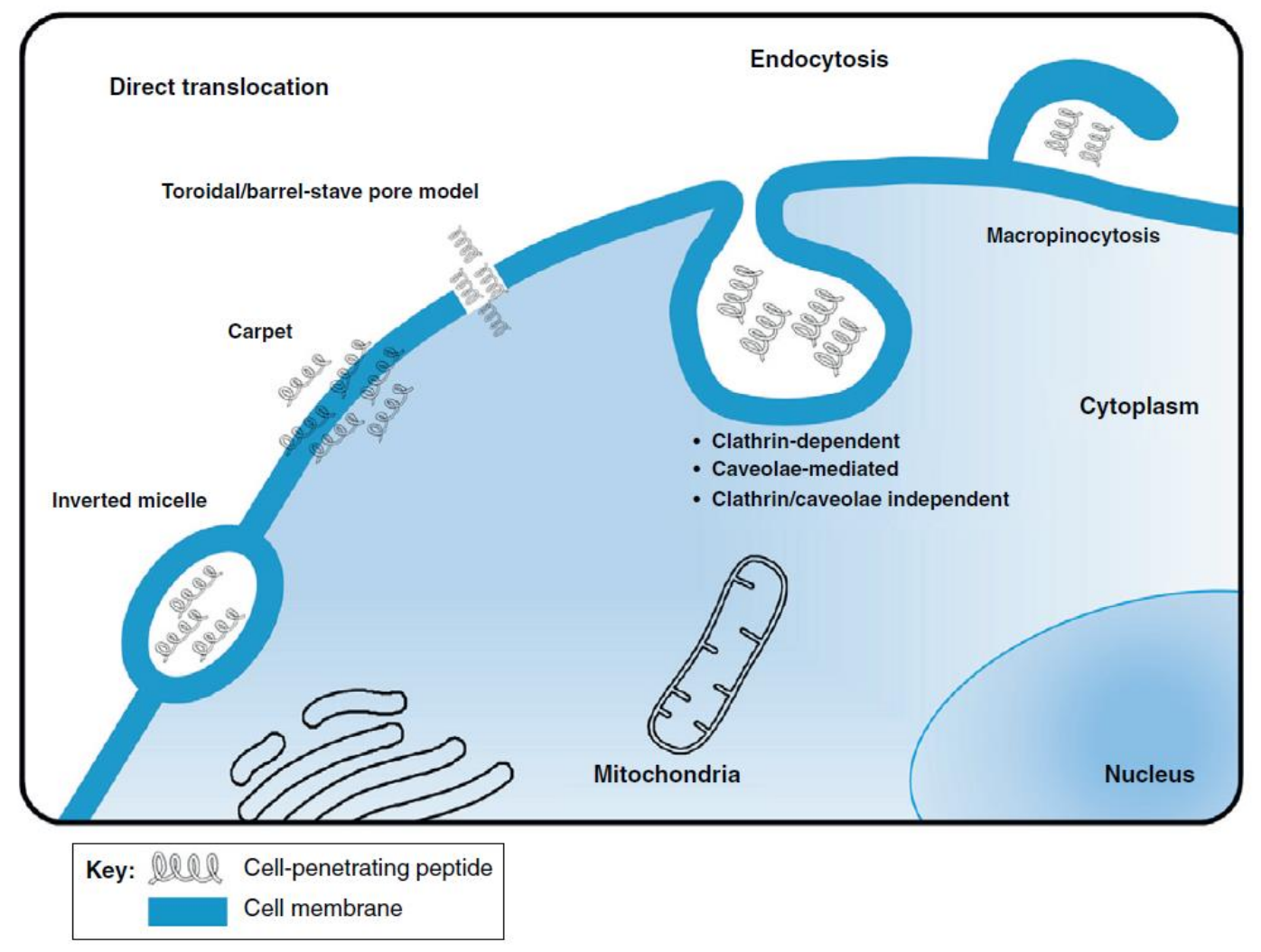

Fig.3. Mechanisms for entry of cell-penetrating peptides into a cell. Reproduced with permission from Ref. 227. Copyright 2012 Elsevier.

The HIV-1 domain peptide TAT (Trans-Activator of Transcription) is a cellpenetrating peptide (CPP) widely used as a vehicle for transport of actives (for example to deliver peptides conjugated to TAT) into cell nuclei. ${ }^{72-75,77,230}$ It was shown to enter HeLa cells when added to culture medium. ${ }^{72-73}$ This transduction domain has high efficiency and is widely used. A shorter TAT peptide core domain RKKRRQRR has been used in several studies on cell internalization ${ }^{231}$ and gene delivery. ${ }^{232}$ Alternative protein transduction domains (PTDs), including those based on other viral proteins are discussed elsewhere. ${ }^{75,233}$ The penetratin peptide RQIKIWFQNRRMKWKK is derived from a DNA-binding protein involved in Drosophila fly morphogenesis. ${ }^{79-81}$ It has an ability to translocate across neuronal membranes where it is conveyed to nuclei. ${ }^{79}$ 
The highly cationic nature of the arginine-rich sequence in TAT peptides is a key to its cell-penetration ability since mammalian cells have membranes rich in zwitterionic lipids such as phosphocholines (microbial cell membranes in constrast contain anionic lipids such as phosphoglycerols). These become polarized in the presence of cationic peptides, especially arginine-rich peptides containing guanidinium groups which form bidentate bonds with $\mathrm{POO}^{-}$moieties (Fig.4). ${ }^{78}$ Arginine-rich cell-penetrating peptides cause membrane pore formation due to the formation of negative Gaussian curvature in the lipid membrane upon interaction with the guanidinium group. ${ }^{12,234-235}$ Since natural cell-penetrating peptides are often rich in arginine residues, synthetic oligoarginines such as octa-arginine have been investigated as vehicles for cellular transport. ${ }^{230,236}$ Cyclic arginine-rich peptides have also been investigated as CPPs. ${ }^{237-}$ 240

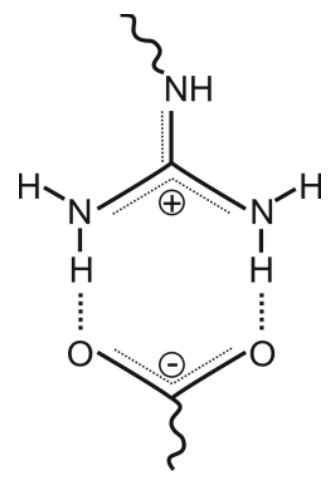

Fig.4. Bidentate binding of guanidinium groups with acidic $\mathrm{XOO}^{-}$groups $(\mathrm{X}=\mathrm{C}, \mathrm{P})$

Cyclic peptides containing the ACDCRGDCFC sequence (identified from a phage display assay of RGD peptides binding to specific integrins including $\alpha_{5} \beta_{1}, \alpha_{v} \beta_{3}, \alpha_{v} \beta_{5}$ and $\alpha_{\mathrm{m}} \beta_{3}{ }^{241}$ ) are selective for $\alpha_{\mathrm{v}}$ integrins and show "tumor-homing" properties when injected into cancerous mice. ${ }^{242}$ Peptides containing the CNGRC sequence were 
identified by similar phase display assays and also exhibit tumor-homing behavior. ${ }^{242-}$ ${ }^{243}$ This peptide contains the cell-adhesive NGR sequence (present in the cell-binding region of fibronectin) located from phase display studies of binding to $\alpha_{5} \beta_{1}$ and $\alpha_{v} \beta_{3}{ }^{42,244}$ The related peptide CGKRK also shows anti-tumor proaptotic properties, and potential in the treatment of glioblastoma. ${ }^{245-246}$ Similarly, within the family of C-terminal R/KXXR/K sequence-containing peptides identified by Ruoslahti et al. as having tissue penetrating properties, the peptide CRGDK shows tumor-homing properties. ${ }^{247-248}$ The Ruoslahti group also identified the CREKA tumor-homing peptide by phage display screening using transgenic breast cancer mice. ${ }^{249}$

\section{Antimicrobial Peptides}

There are several classes of antimicrobial peptides (AMPs). As mentioned in the Introduction, many AMPs of animal origin have longer sequences than consistent with the focus of this review. Nevertheless a variety of shorter ones are considered in this section. One class of short AMP are those rich in arginine residues. Other AMPs include those that are rich in tryptophan, proline- rich peptides, or disulfide-bridged ( $\beta$-hairpin) peptides. ${ }^{12}$ Another category, although not mutually exclusive, is microbially-derived AMPs with cylic headgroups. Some of these antimicrobial peptides are C-terminal amidated ${ }^{13,94}$ although this is not explicitly identified herein. Some AMPs require the presence of counterions for their activity, e.g. $\mathrm{Ca}^{2+}$ for Daptomycin. ${ }^{250}$ This has led to the idea to create novel AMPs bearing organometallic moieties, a strategy to potentially overcome antimicrobial resistance since such units are not encountered in natural AMPs. ${ }^{251}$ 
AMPs act by disrupting bacterial cell membranes, usually mediated by electrostatic interactions between peptide cationic residues and anionic lipoteichoic acids and/or lipopolysaccharides which form the outer structure of the bacterial membrane. A number of detailed mechanisms, for example the "carpet" or "barrel-stave" models (Fig.3) have been proposed. In the former case, it is proposed that the peptide coats the outer membrane, whereas in the latter, transmembrane pores are formed by amphpathic $\alpha$-helical peptides. ${ }^{252}$ These comprise two faces, with one face hydrophobic and the other hydrophilic. These aggregate into pores in membranes with the hydrophilic faces on the interior of the pore.After the initial association with the membrane surface, AMPs can cause membrane pore formation, or thin the membrane or can translocate into the interior. Further details on this can be found in other reviews. ${ }^{8,10-11,13}$ It is recognized that many natural AMPs are rich in the cationic residues lysine or arginine. ${ }^{12,253}$ As mentioned in Section 4, this is also a feature of many cell-penetrating peptides and simply reflects the ability of these peptides to induce membrane lysis. To be useful therapeutically, the lysis needs to be selective to bacterial membranes and not those of eukaryotes. The anti-microbial activity of oligoarginine containing-peptides has been examined, although selectivity for bacterial membranes with minimal cytotoxicity in humans was not demonstrated. ${ }^{254}$

Tryptophan has also been identified as an important residue in several series of important AMPs including several biologically-derived peptides described in more detail below. Model sequences incorporating tryptophan include RRWWRF ${ }^{82}$ and FRWWHR ${ }^{255}$ (both capped at both termini). Tryptophan is weakly hydrophobic and is believed to undergo cation- $\pi$ interactions with cationic species including ions or sidechains of positively charged amino acids. ${ }^{12}$ 
Short natural AMPs include surfactins, fengycins and iturins (Fig.5). ${ }^{256-257}$ All are lipopeptides with a cyclic peptide headgroup, which enhances stability against degradation. Surfactin is a widely studied biosurfactant, and is readily available commercially. ${ }^{83}$ This and other bioactive lipopeptides are attracting attention due to their ready production using fermentation methods. ${ }^{256,258}$ Bacillus subtilis mainly produces three families of lipopeptidic biosurfactant: the surfactins, the fengycins (or plipastatins) and the iturins (including mycosubtilin. ${ }^{257}$ These lipopeptides provide a potentially attractive alternative to chemically synthesized surfactants and they also have potential applications due to their antimicrobial and antifungal properties. ${ }^{84-85}$, ${ }^{256-257}$ As well as the afore-mentioned antimicrobial and antifungal activity, these compounds also have other potential uses in biomedicine, ${ }^{256,259}$ for instance exhibiting anti-tumor properties. Some related natural cyclic antimicrobial and antifungal lipopeptides are discussed in a recent review on the self-assembly and bioactivity of lipopeptides. ${ }^{260}$
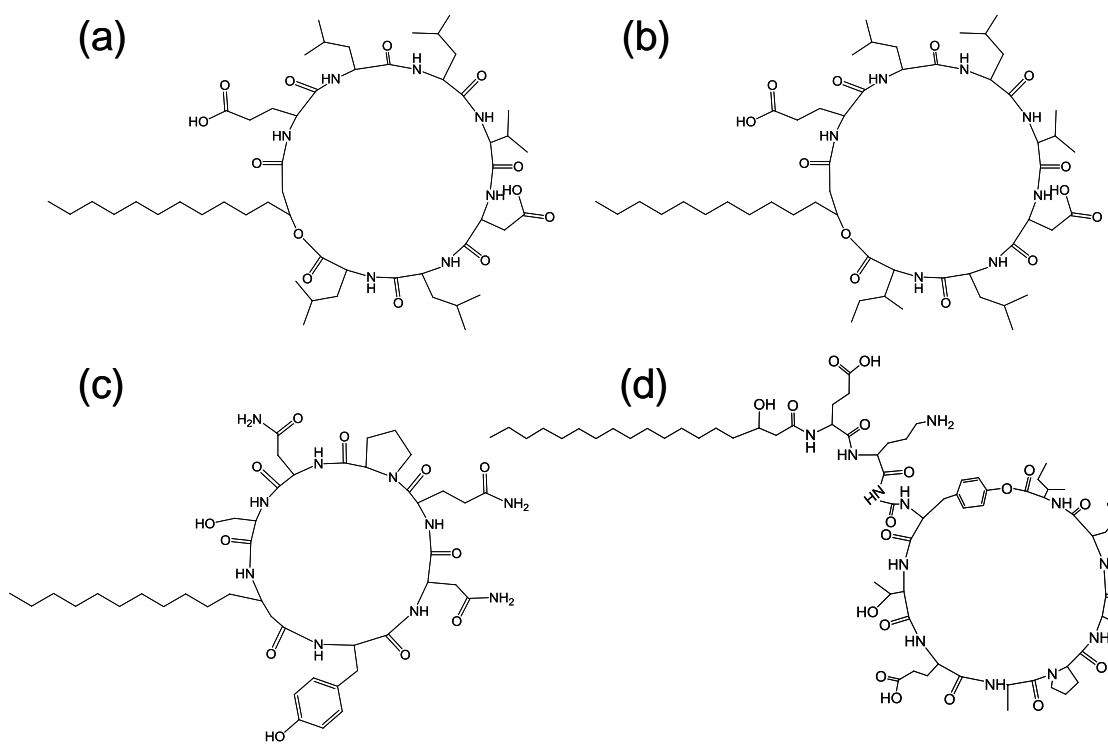

(d)

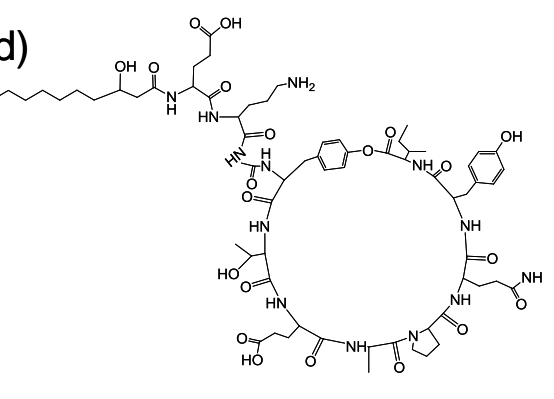


Fig.5. Structure of some lipopeptides produced by B. subtilis. ${ }^{260}$ (a) Surfactin (b) Lichenysin, (c) Iturin A, (d) Fengycin/plipastatin A. Adapted with permission from Ref. ${ }^{261}$ Copyright 2013 Royal Society of Chemistry.As detailed in ref. ${ }^{257}$, the expressed lipopeptides actually comprise a mixture of lipid chain lengths. The bioderived materials comprise a mixture of molecules with different lipid chain lengths.

The bacitracins are a series ${ }^{86-89}$ of related cyclic lipopeptides (Fig.5a) with activity against Gram-positive bacteria due to their influence on the peptidoglycan synthesis in the bacterial cell wall. These compounds were originally derived from B. subtilis and B. lichenformis. ${ }^{87}$ Lichenysins, ${ }^{262-263}$ pumilacidins ${ }^{264}$ and the polymyxin B peptides (Fig.6b) ${ }^{91}$ are classes of antimicrobial molecules produced by Bacillus licheniformis, Bacillus pumilus and Bacillus polymyxa respectively. ${ }^{260}$ Lichenysin A is a powerful surfactant, and antimicrobial activity against several gram positive and gram negative bacteria, although not as great as that observed for surfactin. ${ }^{262}$ Several pumilacidins show antiviral activity against herpes simplex virus as well as anti-ulcer activity. ${ }^{264}$ Polymyxin B (Fig.6b) and polymyxin E (colistin) show antibiotic activity against a range of gram-negative bacteria. ${ }^{91}$ The two molecules are distinguished by the substitution of a D-leucine in colistin with a D-phenylalanine in polymyxin $\mathrm{B} .{ }^{90}$ The mode of action of these lipopeptides has been proposed to be membrane disruption due to interaction between the cationic polymyxin and the anionic bacterial outer membrane leading to a detergent-like activity. ${ }^{91} \mathrm{~A}$ wide range of other cyclic depsipeptide (in which one or more amide groups are replaced by the corresponding ester goup) and N-methylated peptide (peptoid) antibiotics have been investigated. ${ }^{38,}$ 
(a)

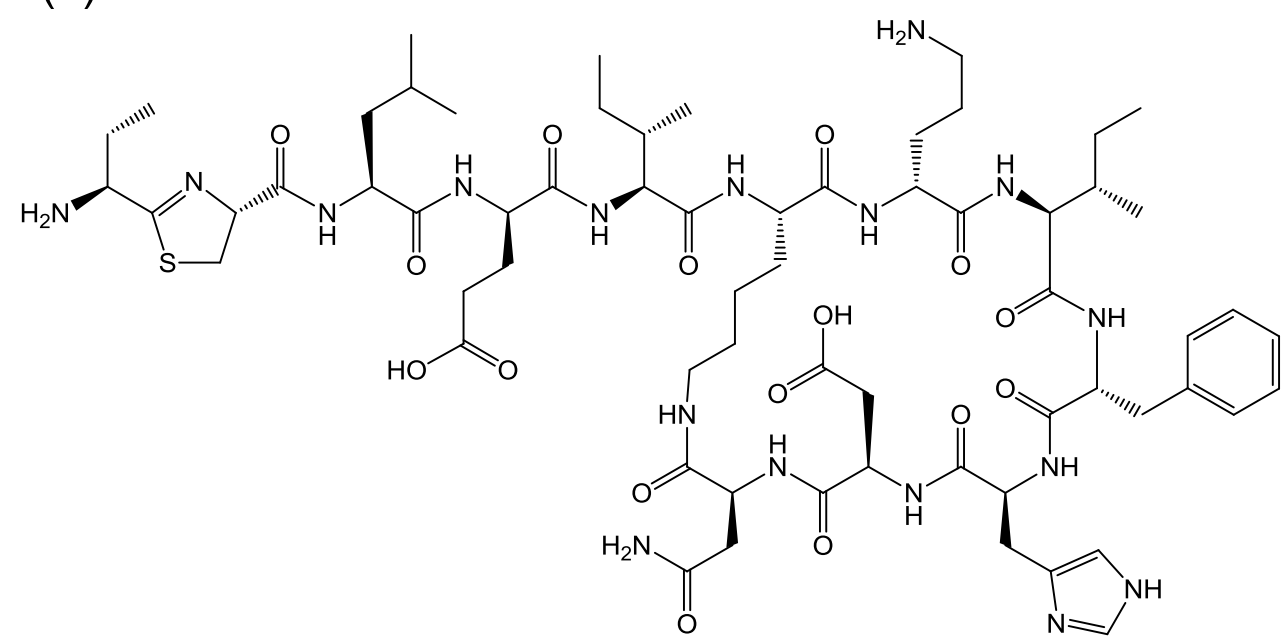

(b)

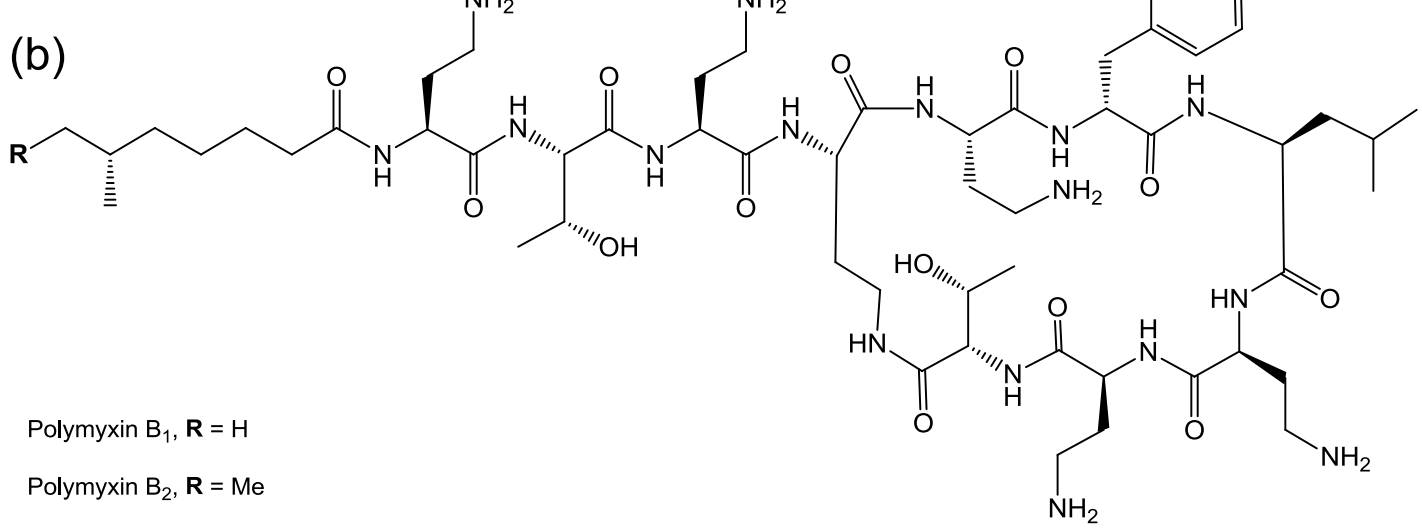

Fig.6. Molecular structures of (a) bacitracin $A_{1},{ }^{89}$ polymyxin $B_{1}$ and $B_{2} .{ }^{38,90}$

The two tachyplesin antimicrobial peptides contain four cysteines forming two disulfide bridges to give a bicyclic peptide (Fig.7). These peptides, originally obtained from horseshoe crabs, are highly cationic containing five residues. ${ }^{7,13,92}$ The class of protegrin peptides (from porcine leukocytes), protegrin-1 to protegrin-5, have a similar bicyclic structure, containing six arginines. ${ }^{13,93-94}$ Defensins are longer cysteine-rich antimicrobial peptides isolated from a variety of animals. ${ }^{7-8,13,94-96}$ These peptides are too long to be considered further in this review. Bactenicin with 
sequence RLCRIVVIRVCR is bridged by a single disulfide bond. ${ }^{7-8,13,97}$ It is obtained from bovine neutrophils and is among the shortest bio-derived cationic AMPs ${ }^{267}$ Many other antimicrobial peptides have been and are being discovered from natural sources such as soil (e.g. the newly discovered antibiotic teixobactin ${ }^{268}$ as well as the gramicidins discussed below) or organisms such as amphibians (e.g. magainin ${ }^{94,269}$ ) or spiders (e.g. gomesin ${ }^{94,270}$ ). However, these are also not discussed in detail here, as the sequences are too long. Summaries of natural antimicrobial peptides from plants and animals are available in the literature..$^{8,10,13,94,271-272}$

(a) 


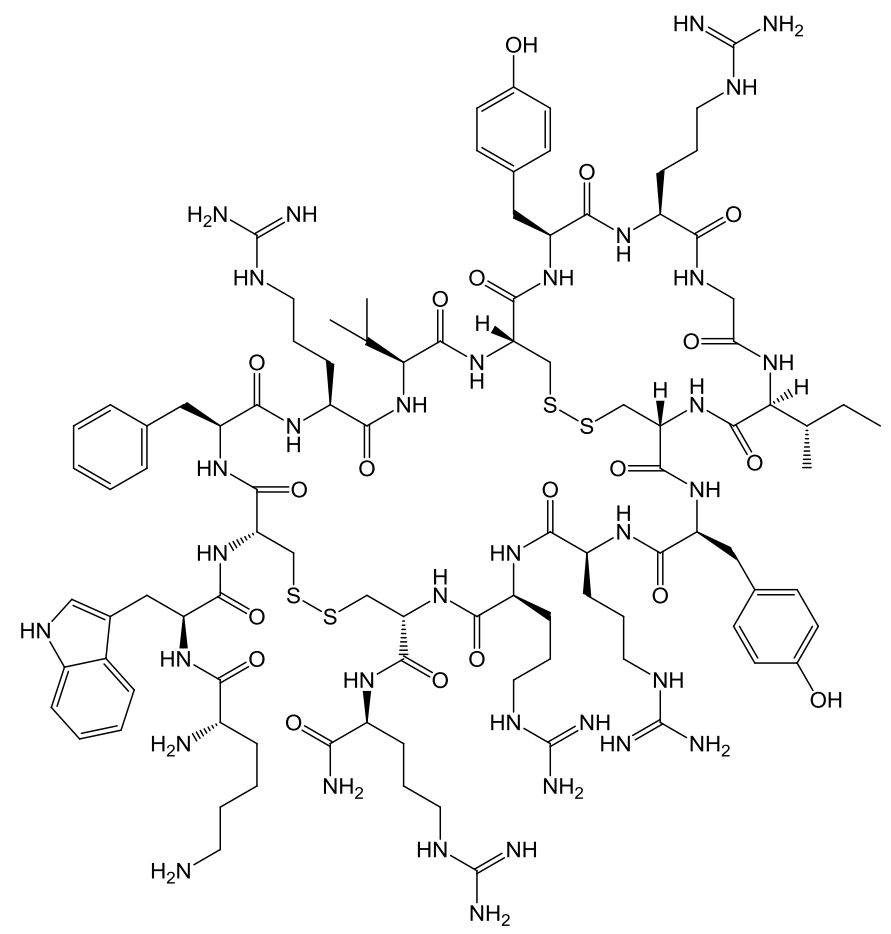

(b)

KWCFRVCYRGICYRRCR

Fig.7. (a) Molecular structure of tachyplesin $1 .{ }^{92}$ (b) Sequence code with S-S bridge location indicated.

The gramicidins are a series of 15-residue peptides active against Gram-positive bacteria, being derived from the soil bacterial species Bacillus brevis. The peptides have the sequence with alternating L- and D- residues, formyl-XGAlAvVvWlYlWIWethanolamine, where $\mathbf{X}$ is $\mathrm{V}$ or I and $\mathbf{Y}$ is W (gramicidin A), ${ }^{273} \mathrm{~F}$ (gramicidin B) ${ }^{89,274-}$ 275 or Y (gramicidin C) ${ }^{89,274-275}$ Gramicidin D is a mixture of related peptides ${ }^{276}$ and Gramicidin $\mathrm{S}$ is the cyclic decapeptide cyclo(VOLfP $)_{2}\left[\mathrm{O}\right.$ : ornithine]. ${ }^{7}$ Gramicidins are interesting antimicrobial peptides without cationic residues. They form $\beta$-helix dimers which span the lipid bilayer, ${ }^{277-279}$ causing the formation of selective ion 
channels, rather than causing bacterial cell lysis due to electrostatic binding as in the case of the cationic AMPs discussed above.

Among animal-derived host defense peptides, those with short sequences include indolicidin and bactenicin. Indolicidin, which is cow-derived (from bovine neutrophils), has the sequence ILPWKWPWWPWRR ${ }^{7,11,13,98}$ and can be seen to be tryptophan-rich. Peptides rich in this residue can have antimicrobial properties as well as arginine-rich ones, ${ }^{12}$ and in fact indolicidin is stated to be have the highest tryptophan content of any "protein". ${ }^{98,280}$ A number of studies also point to anti-viral activity of indolicidin. ${ }^{10}$ Derivatives of the wasp venom peptide mastoparan ${ }^{281}$ with sequence INLKALAALAKKIL are being investigated as potential antimicrobial agents despite the toxicity of the parent peptide to mammalian cells. ${ }^{282}$ The derivative mastoparan-X INWKGIAAMAKKLL has had its conformation in solution determined by $\mathrm{NMR}^{283}$ which reveals it to be surely one of the shortest $\alpha$-helix forming peptides (Fig.8).

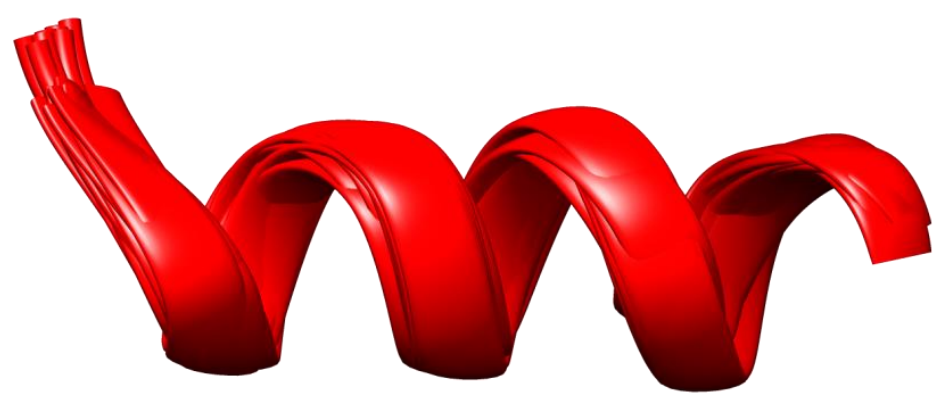

Fig.8. Structure from solution NMR of Mastoparan-X (pdb: 2CZP). ${ }^{283}$

Helical peptides containing the KLAK sequence have been shown to possess selective and potent antimicrobial activity with low mammalian cytotoxicity. ${ }^{284}$ Antimicrobial 
activity was demonstrated for both Gram-negative E. coli and Gram-positive $S$. aureus. ${ }^{284}$ The (klakkla)2 peptide (in its D-amino acid form to reduce proteolysis) was conjugated to 'tumour homing' sequences cyclo(CNGRC) or double cyclic ACDCRGDCFC to create anti-cancer peptides which showed anti-cancer activity in mice. $^{285}$

Daptomycin is a potent AMP which is a cyclic branched 13-residue peptide produced by the Gram-positive bacterium Streptomyces roseosporous. ${ }^{99-100}$ It is also known under the tradename Cubicin and is used as an antibiotic to treat serious infections caused by Gram-positive bacteria. ${ }^{101,250}$ It is effective against infections where antimicrobial resistance is a problem, including methicillin-resistant Staphylococcus aureus (MRSA) ${ }^{100}$ and vancomycin-resistant Enterococci. ${ }^{101,286}$ There are two katanosin cyclic depsipeptides with antimicrobial activity. Katanosin B is also known as lysobactin (originally isolated from a strain of Lysobacter) ${ }^{287-289}$ and katanosin A has a similar structure with a V7I substitution. ${ }^{289}$ Both are potent AMPs with activity against Gram-positive bacteria such as Staphylococci. ${ }^{287-289}$

The echinocandins are a class of cyclic peptides with antifungal activity. They operate by blocking cell wall glucan synthesis. ${ }^{290-292}$ Anidulafungin, caspofungin and micafungin are all examples of echinocandins (Fig.9). ${ }^{38,260}$ The most widely known is caspofungin, marketed as a drug by Merck and Co. The antifungal activity of this class of compound is due to the interaction of lipopeptide molecules with the insoluble polysaccharide component of the cell wall of fungal cells, specifically in the due to the inhibition of the synthesis of glucans. ${ }^{290}$ The interactions of echinocandins with Candida fungi such as C. albicans has been particularly well studied. ${ }^{290-291}$ 


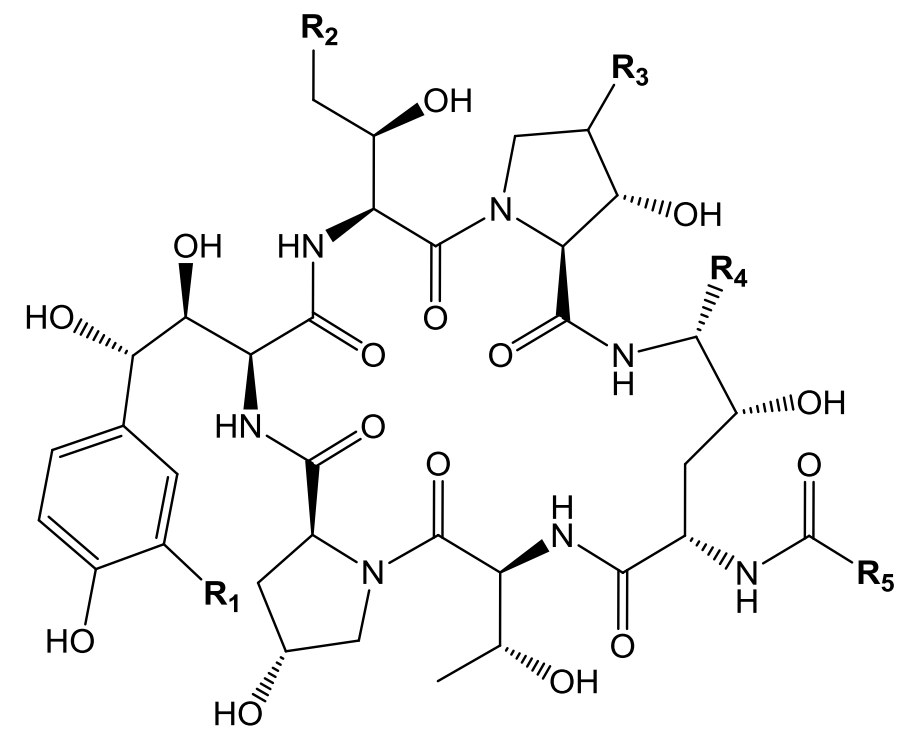

$$
\mathbf{R}_{\mathbf{1}}
$$

$\mathbf{R}_{\mathbf{2}}$

$\mathbf{R}_{\mathbf{3}}$

$\mathbf{R}_{\mathbf{4}}$

$\mathbf{R}_{\mathbf{5}}$

caspofungin

$\mathrm{H}$

$-\mathrm{NH}_{2}$

$\mathrm{H}$<smiles>NCCN</smiles>

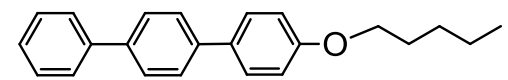

anidulafungin

$\mathrm{H}$

H

$\mathrm{Me}$

$\mathrm{OH}$

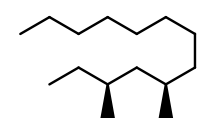

micafungin

$\mathrm{O}-\mathrm{SO}_{3} \quad \mathrm{H}_{2} \mathrm{~N}=\mathrm{O}$

$\mathrm{Me}$

$\mathrm{OH}$

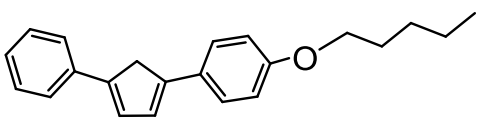

Fig.9. Structures of caspofungin, anidulafungin and micafungin. Adapted from ref. ${ }^{38}$

Beauvericin (Fig.10) is a symmetric cylic depsipeptide (strictly, peptoid as the amides are $N$-methylated) with antifungal and insecticide properties. ${ }^{293-294}$ It was originally isolated from a fungus, ${ }^{295}$ and is structurally related to the enniatin family of cyclohexa-depsipeptides. ${ }^{296}$ 
<smiles>CC(C)[C@H](OC(=O)[C@H](Cc1ccccc1)N(C)C(=O)[C@H](OC(=O)[C@@H](Cc1ccccc1)N(C)C(=O)[C@@H](Cc1ccccc1)N(C)C(=O)[C@H](Cc1ccccc1)C(C)C)C(=O)O[C@H](Cc1ccccc1)C(C)C)C(=O)O</smiles>

Fig.10. Molecular structure of beauvericin. ${ }^{295}$

\section{Peptide Hormones}

There are many peptide hormones with diverse biological activities in signaling and other response pathways. ${ }^{15-16,18-19}$ Several classes of peptide hormones have sequences too long to be considered further here but there are nonetheless several of them with short sequences and important biological functions.

Oxytocin is a member of a series of related peptide hormones which are nonapeptides with an intramolecular disulfide bond which produces a small cyclic ring (Fig.11a). ${ }^{63}$ Oxytocin is known as the love hormone, due to putative activity in social bonding. ${ }^{297-}$ ${ }^{300}$ It is used medically to facilitate childbirth (it simulates uterine contractions) ${ }^{63,}, 103$ and milk secretion. ${ }^{103}$ The vasopressins are a series of peptide hormones with similar structures to oxytocin, i.e. they are 9-residue peptides containing a disulfide bond which creates a cyclic region within the molecule. ${ }^{63}$ Vasopressins act as vasoconstrictors and are thus targets for blood pressure modulation. ${ }^{63}$ They also stimulate water resorption by the kidneys and are thus antidiuretic agents. ${ }^{63}$ Arginine 
vasopressin, with sequence CYFQNCPRG stabilized by an intramolecular disulfide bridge between the two cysteine residues, is the basis for the antidiuretic (and anticoagulant) desmopressin which has the arginine vasopressin sequence but with the first $\mathrm{C}$ residue deamidated and with D-Arg instead of L-Arg (Fig.11b). ${ }^{301}$

(a)

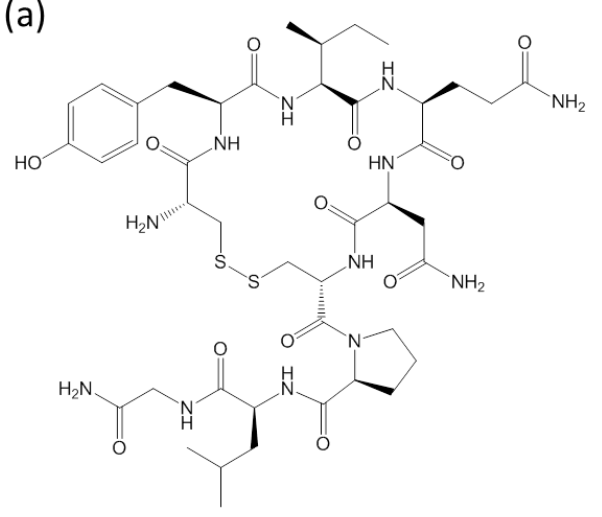

(b)

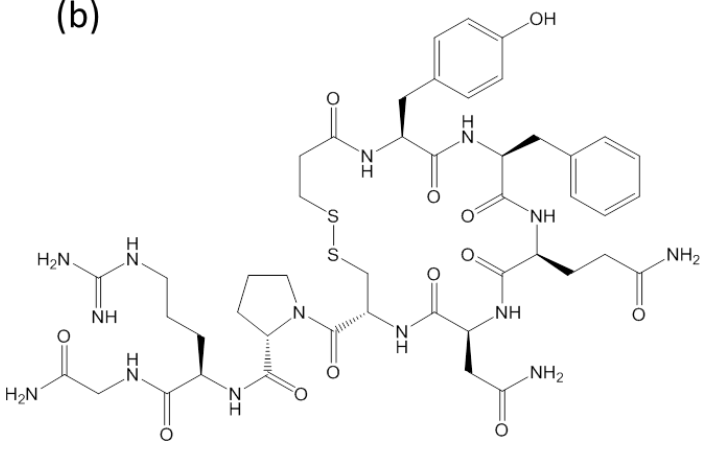

Fig.11. (a) Molecular structures of (a) Oxytocin, (b) Desmopressin.

The angiotensins are a series of four linear peptide hormones. The first, angiotensin I is obtained by cleavage of the angiotensinogen protein by renin. ${ }^{103-105}$ Angiotensin I contains 10 residues NRVYIHPFHL, angiotensin II is derived from this by cleavage of the two C-terminal residues, ${ }^{103-105,302}$ angiotensin III is the heptapeptide RVYIHPF and angiotensin IV is the core hexapeptide VYIHPF. ${ }^{104,302}$ Angiotensin II has the important bioactivity of vasoconstriction and blood pressure increase. ${ }^{104}$ It is produced from Angiotensin I by angiotensin-converting enzyme (ACE) and hence ACE inhibitors are therapeutic agents for blood pressure reduction and cardiovascular disease. ${ }^{303-304}$ Angiotensin II receptor antagonists are also important therapeutic agents. Angiotensin II has an identified role in inflammation and it can regulate growth factors and cytokines. ${ }^{305}$ 
Bradykinin, with the sequence RPPGFSPFR, is a short peptide hormone with activity in blood vessel dilation (vasodilation), hence in reduction of blood pressure. ${ }^{106}$ It is also associated with inflammatory pain. ${ }^{107-108}$ The angiotensin converting enzyme (ACE) inhibitors increase bradykinin production. ${ }^{106}$

Somatostatin, also known as growth hormone-inhibiting hormone, is a 14-residue cyclic peptide (Fig. 12). ${ }^{306}$ It plays an important role in cell proliferation (via inhibition of the secretion of growth factors and cytokines) ${ }^{307}$ and neurotransmission. ${ }^{308}$

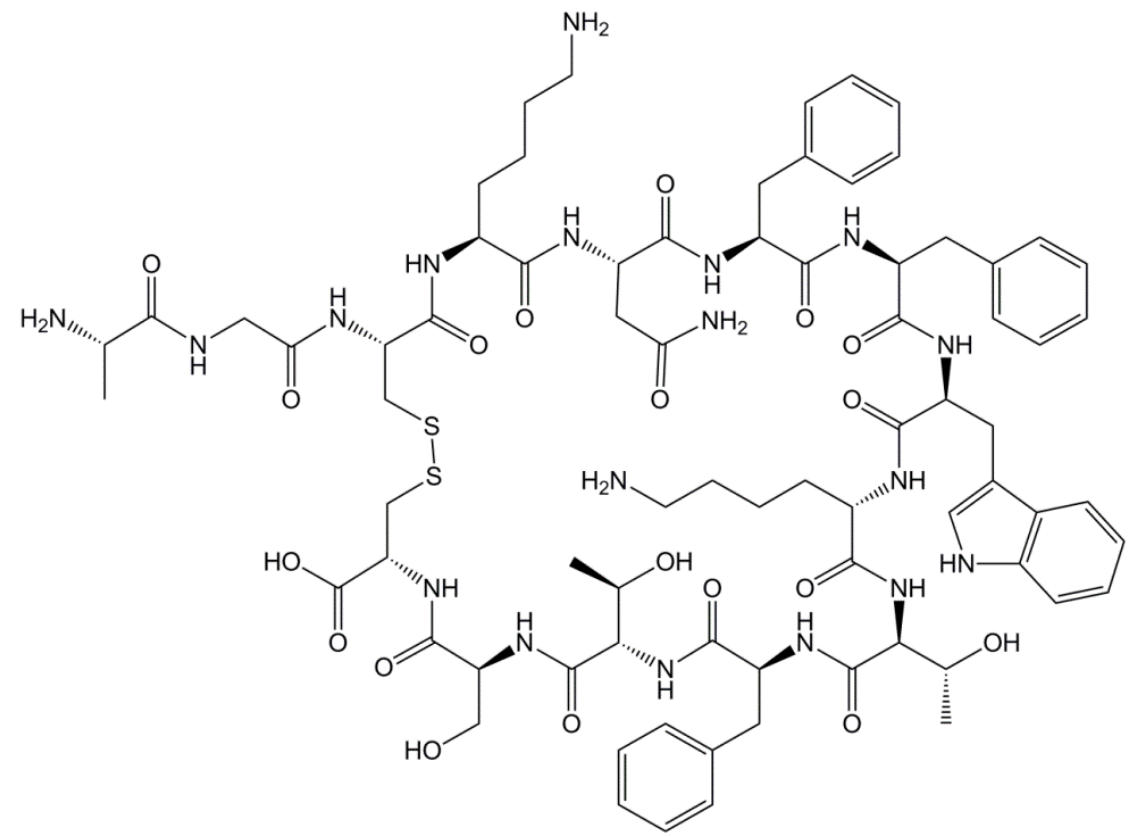

Fig.12. Molecular structure of somatostatin.

Octreotide (tradename Sandostatin) is a cyclic octapeptide (Fig.12) that mimics the activity of somatostatin. ${ }^{115-116}$ It was designed to have enhanced in vivo stability due to the inclusion of D-amino acids as well as other modifications. The D-configuration of tryptophan fosters a bioactive conformation, based on a $\beta$-turn centered on wK. 
Octreotide is a powerful growth hormone inhibitor which can be used to treat the growth hormone disorder acromegaly for example. ${ }^{115,309}$ Lanreotide is another longacting analogue of somatostatin. Both octreotide and lanreotide act on the same receptors as somatostatin ( $\mathrm{G}$ protein-coupled somatostatin receptors) and both are inhibitors of insulin and glucagon. ${ }^{119}$ Lanreotide is a homologue of octreotide (Fig.13). ${ }^{117-119}$ It self-assembles into nanotubes in aqueous solution. ${ }^{310-313}$

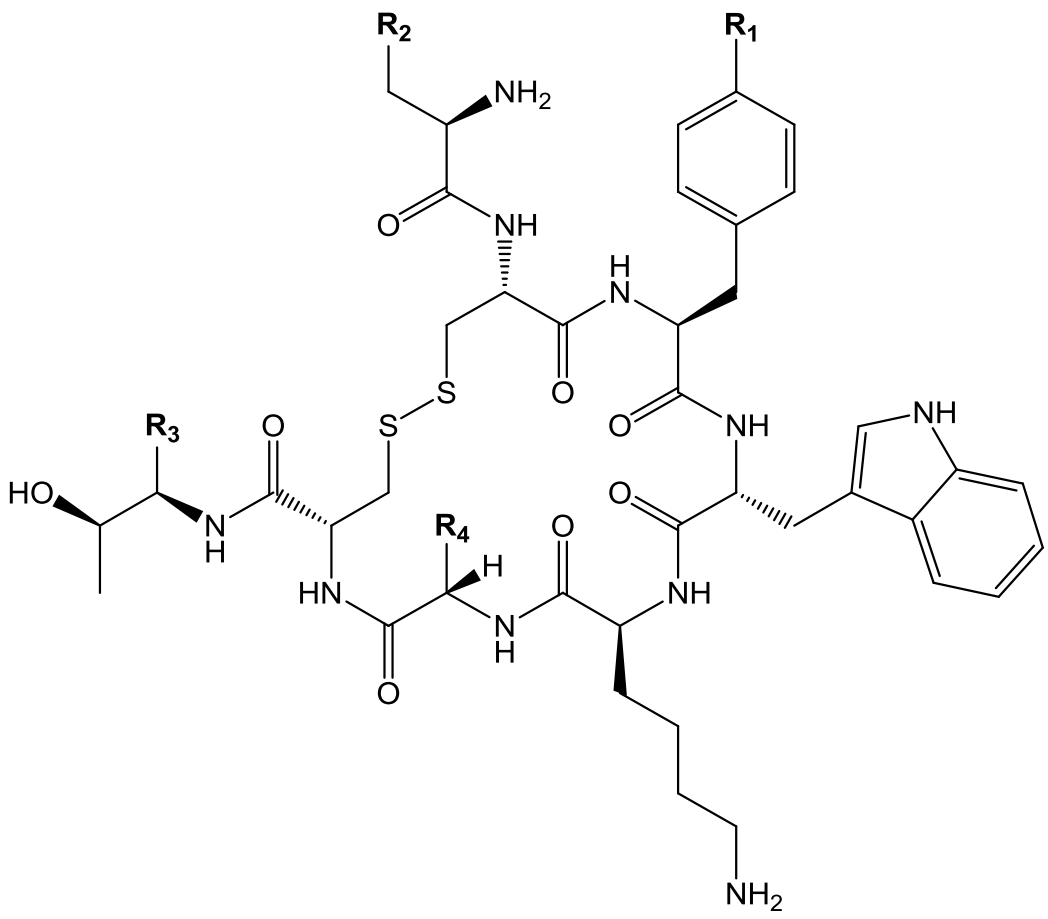

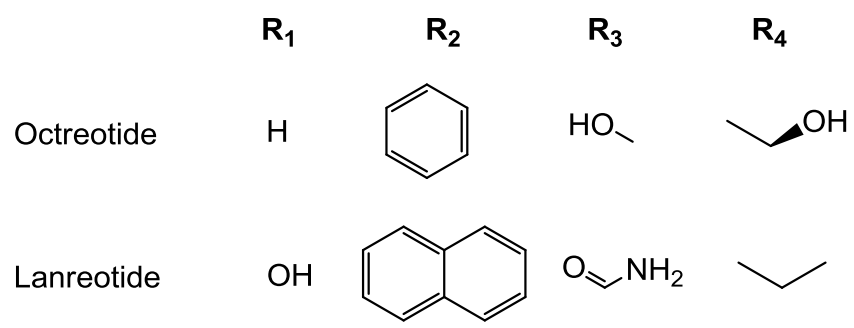

Fig.13. Molecular structures of octreotide ${ }^{115}$ and lanreotide. ${ }^{119}$

Luteinizing hormone releasing hormone (LHRH) also known as gonadotropinreleasing hormone $(\mathrm{GnRH})$ is a decapeptide with sequence pGHWSYGLRPG (pG: 
pyroglutamic acid, Fig. 14b). ${ }^{114}$ This peptide, produced in the hypothalamus, binds to the LHRH receptor, and triggers the release of luteinizing hormone (LH) and the follicle stimulating hormone (FSH), which are responsible for the production of testosterone and sperm, respectively. ${ }^{109}$ Another tropic (i.e. having endocrine glands as target) peptide hormone produced in the hypothalamus is TRH, thyrotropinreleasing hormone (Fig.14a). ${ }^{110}$ This tripeptide (L-proline-L-histidyl-L-pyroglutamyl amide or 5-oxo-L-prolyl-L-histidyl-L-prolinamide) also contains the pyroglutamyl residue. It has the commercial name protirelin and is used in the diagnosis of thyroid disorders among other applications. ${ }^{111-113}$<smiles>NC(=O)[C@@H]1CCCN1C(=O)[C@H](Cc1cnc[nH]1)NC(=O)[C@@H]1CCC(=O)N1</smiles>

(b)<smiles>O=C1CC[C@H](C(=O)O)N1</smiles>

Fig.14. Molecular structure of (a) thyrotropin-releasing hormone, (b) pyroglutamic acid.

Gastrin stimulates the secretion of gastric acid in the stomach. Gastrin peptide hormones have a common C-terminal motif. There are several variants (some too long to fit within the scope of this review) such as minigastrin or gastrin-14, WLEEEEEAYGWMNF. ${ }^{314}$ Tetragastrin (WMNF) is discussed further in Section 9.

\section{Tissue Engineering and Biomaterials Development}


Cell adhesion motifs which are key sequences in the design of biomaterials for tissue engineering are discussed in Section 3. Here, several additional components that are desirable in materials which can remodel in response to cellular cues are considered.

Growth factors are important in tissue engineering and wound healing. A list of growth factors involved in different processes (angiogenesis, wound healing etc) is available. ${ }^{315}$ Growth factors are large native proteins, however short peptide substrates for growth factors have been identified. The peptide YRSRKYSSWYVALKR, taken from a sequence FGF(106-120) is an activator of the basic fibroblast growth factor (FGF-2 or bFGF) receptor. ${ }^{316}$

The GPQGIAG sequence is a substrate for MMP-1 and MMP-2 (which cleave between $\mathrm{G}$ and I) and has been used in the development of many biomaterials for tissue engineering applications. ${ }^{1,132,317-318}$ An excellent review on MMP substrate sequences is available. ${ }^{132}$ Other agents involved in tissue remodeling include the plasminogen enzymes. These degrade blood clots in the process of thrombolysis, i.e. they degrade fibril in the process of fibrinolysis. A list of tetrapeptide plasminogen activator cleavage sites is available. ${ }^{2}$ All have $\mathrm{N}$ terminal arginine residues and at least one other polar residue (serine, threonine or arginine). Elastase is a protease enzyme which degrades elastin (Section 3). It acts on substrates containing oligoalanine repeats. ${ }^{319-320}$ The serine protease $\alpha$-chymotrypsin cleaves selectively following aromatic residues, ${ }^{321}$ e.g. in KLVFF-based peptide conjugates. ${ }^{322-323}$ The substrate specificity for other serine proteases has been investigated. ${ }^{324-325}$ Other substrates for degradation used in biomaterials for tissue engineering include the 
APGL collagenase degradation sequence and the VRN substrate for plasmin mediated degradation. $^{55}$

Heparin-binding peptide sequences are also an important component of biomaterials for applications in wound healing since heparin is a powerful anticoagulant. Heparinbinding peptide sequences include FAKLAARLYRKA from Antithrombin III, 2, 326 and others. ${ }^{69}$

The "RAD16" RADARADARADARADA peptide (and similar variants) became a commercial product (PuraMatrix) with applications in tissue engineering as hydrogels of this peptide can support the growth of various types of cell. ${ }^{127-129}$

\section{Amyloid Peptides}

Amyloid peptides form $\beta$-sheet fibril structures. Those discussed here are either simple alternating sequences or fragment peptides from disease-related amyloid peptides or proteins.

Alternating sequences such as GAGA in silk discussed above favour $\beta$-sheet formation. The presence of alternating hydrophobic and hydrophilic residues further enhances amyloid aggregation propensity. For example, the peptide EAK16 $(\mathrm{AEAEAKAK})_{2}$ was among the first to be studied which is consistent with this design rule, with the additional feature that the charge of the hydrophilic residue changes in a sequenced fashion. ${ }^{126}$ This peptide is present in the yeast protein zuotin. The Zhang group also studied related peptides such as KFE12, FKFEFKFEFKFE, with 
alternating charged residues. ${ }^{327-328}$ This peptide forms gels in suitable salt solutions. ${ }^{328}$ As mentioned above, the "RAD16" RADARADARADARADA peptide is an amyloid former. ${ }^{127-129}$ The structural and rheological properties of similar octapeptides (which can form $\beta$-sheet hydrogels) with alternating residues such as FEFEFKFK have been investigated. ${ }^{329-332}$ The influence of the amino acid pattern on the self-assembly motif of this class of octapeptide has been examined..$^{333}$

Due to the intense research interest in amyloid formation of relevance to protein misfolding diseases including Alzheimer's, Parkinson's, type II diabetes etc., ${ }^{25}$ much work has been done using model amyloid forming peptides. The following describes a few key model amyloid peptides and is not a full list since so many have been investigated. Some well-known sequences now have X-ray crystal structures determined, and a selection of the more widely used model peptides are discussed in the following. ${ }^{28,125}$

One widely studied amyloid-forming peptide is GNNQQNY from the yeast prion protein Sup35. Among many studies of its amyloid properties can be highlighted fibre diffraction studies ${ }^{121}$ and a crystal structure determination which reveals the formation of a steric zipper (Fig.15) in which the side chains are intercalated within the cross- $\beta$ structure. ${ }^{122,125}$ Other examples of steric zippers, which exclude water from the interior of amyloid fibrils, include phenylalanine zippers. ${ }^{334-335}$

The VQIVYK sequence from tau (residues 306-311) forms $\beta$-sheet filaments, ${ }^{123}$ with a cross- $\beta$ structure. ${ }^{124,336}$ A crystal structure determination is available, which reveals a steric zipper arrangement. ${ }^{125,337}$ 


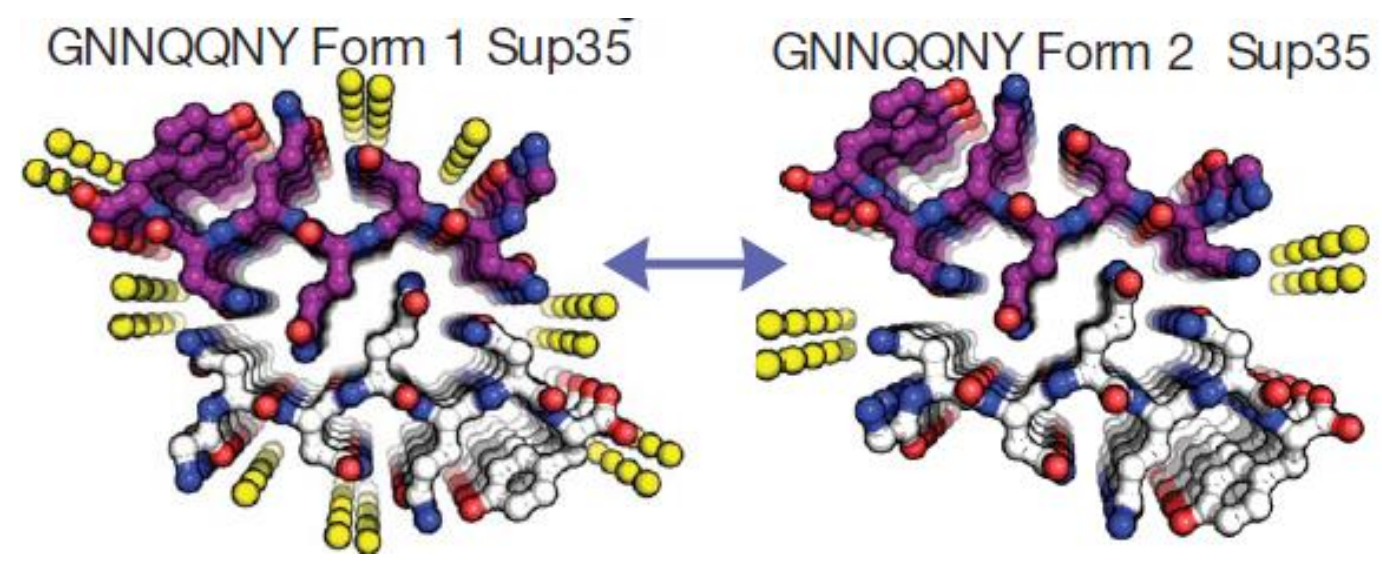

Fig. 15. Amyloid steric zipper structures from $x$-ray crystallography on GNNQQNY.${ }^{125}$ Carbon atoms are purple or white, nitrogen atoms are blue and oxygen atoms are red. The yellow circles indicate water molecules.

Deposits of human islet amyloid polypeptide (hIAPP) also known as amylin are found in the pancreas of people with type II diabetes. ${ }^{338-340}$ The peptide NFGAIL from hIAPP has been extensively used as a model amyloid-forming peptide, ${ }^{341}$ following its identification as a minimal $\beta$-sheet forming sequence. ${ }^{342}$ Importantly, a crystal structure of NNFGAIL is available and this shows unusual features for an amyloid peptide, specifically a pronounced bend around the $G$ residue and a lack of side chain interpenetration as in a typical steric zipper arrangement. ${ }^{343}$

The peptides KLVFF and KLVFFAE from the Amyloid $\beta$ (A $\beta$ ) peptide (residues 1620 and 16-22 respectively) are believed to be a core aggregating sequences. ${ }^{344-346}$ Indeed, peptides incorporating this fragment can bind the full length peptide and prevent fibrillization. ${ }^{347}$ Fragments based on KLVFF have been designed to inhibit $\mathrm{A} \beta 40$ and $\mathrm{A} \beta 42$ fibrillization. Rational design principles based on the knowledge of the pentapeptide binding sequence led to the preparation of LPFFD, ${ }^{102}$ now known as the $\beta$-sheet breaker peptide. This peptide incorporates proline, known to hinder $\beta$ - 
sheet aggregation and was found to reduce amyloid deposition in vivo (rat model) and to disassemble pre-formed fibrils in vitro. ${ }^{102}$

The FF dipeptide is a fragment of KLVFF (and of course other peptides) and it was suggested that its $\pi$-stacking has an important role in amyloid formation. ${ }^{348} \mathrm{FF}$ has remarkable self-assembly properties, although it does not form strictly amyloid $\beta$ sheet structures. ${ }^{349-350}$ This peptide forms nanotubes in aqueous solution ${ }^{130,349}$ and in organic solvents it is possible to prepare vesicles or nanoparticles from it. Capped FF can form fibrils or nanotubes depending on the nature of the capping group, ${ }^{351-352}$ and vertical arrays of nanotubes can be prepared from FF (with different capping groups) by spreading a film from HFIP. ${ }^{353}$ The aggregation of peptides through aromatic stacking interactions can be enhanced by additional of bulky aromatic units such as Boc [tert-butoxycarbonyl] or Fmoc. ${ }^{354-355}$ Boc-FF can form nanospheres in water as a transient in the nanotube formation process, ${ }^{356}$ or stable nanospheres with very high stiffness in organic solvent. ${ }^{357}$ The uncapped FF dipeptide can also form nanospheres (“quantum dots") in organic solvents. ${ }^{358}$ Strategies other than addition of bulky aromatic substituents have been used to modulate the self-assembly of FF. One is to incorporate halogenated phenylalanine,${ }^{359-361}$ or other substituted phenylalanine derivatives. ${ }^{361}$ Other approaches include changing chirality, i.e. substitution with the D-amino acid, ${ }^{362}$ or N-terminal derivatization with other aromatic groups. ${ }^{354-355,363-364}$

Computational methods have recently been used to assess the aggregation propensity of all of the $20^{3}=8000$ tripeptides. ${ }^{365}$ After the computational screening, candidates were synthesized and assessed for hydrogelation ability based on $\beta$-sheet fibril network formation. 


\section{Neuropeptides, Antioxidants and Immune-Related Peptides}

There are two enkephalin peptides Met-enkephalin YGGFM and Leu-enkephalin YGGFL which are endogenous ligands for $\mu$-opioid receptors in the brain. ${ }^{103,133}$ Dalargin with sequence YaGFLR (a: D-alanine) is a Leu-enkephalin analogue with specificity for $\mu$ opioid receptors. ${ }^{366}$ Dalargin is usually excluded from the brain however lipidation leads to a self-assembled fibril structure, which is reported to both reduce degradation in plasma and enables transport across the blood-brain barrier. ${ }^{367}$ The endomorphin tetrapeptides have high selectivity and affinity for the $\mu$-opioid receptors. ${ }^{134}$ Two endomorphin peptides were isolated from brain extracts.

Endomorphin-1 has the sequence YPWF and endomorphin-2 has the sequence YPFF. These peptides are of interest for the further development of pain relief therapies. However, it has to be noted that the direct application of these peptides in analgesia was demonstrated in a rodent model by i.c.v. (intracerebroventricular) administration. ${ }^{135}$ Peripheral administration of these peptides is ineffective as they are too easily degraded, appropriately modified versions may be designed to circumvent this.

Substance $\mathrm{P}$ is the undecapeptide RPKPQQFFGLM which acts as a neurotransmitter and is involved in pain and analgesia. ${ }^{368-369}$ It is a member of the tachykinin family of neuropeptides which have the common C-terminus FXGLM $^{136}$ where $\mathrm{X}$ is a hydrophobic residue.

Another class of neuroactive peptides are the tryptophan-containing non-ionizable opioid peptides such as the naturally occurring (fungus derived) tetrapeptide 
cyclo[Phe-D-Pro-Phe-Trp], known as CJ-15208. ${ }^{38,370}$ This peptide is an orallyavailable antinociceptive (it blocks pain stimuli by sensory neurons). It is able to cross the blood-brain barrier and reach opioid receptors. ${ }^{370}$

A series of fragments of the cholecysotokinin peptide are found naturally.

Cholecystokinin is a gastric peptide, identified as a 33-residue peptide in porcine intestine extracts. ${ }^{371}$ It causes the release of digestive enzymes and acts as a satiety signal. ${ }^{372-373}$ Cholecystokinin octapeptide (CCK-8) has the sequence $\mathrm{NY}\left(\mathrm{SO}_{3} \mathrm{H}\right) \mathrm{MGWMNF}$ (i.e. it contains a sulfated tyrosine residue). ${ }^{371}$ Cholecystokinin tetrapeptide (CCK-4), also known as tetragastrin, is a peptide fragment derived from the larger peptide hormone cholecystokin and has the sequence WMNF. It is an anxiolytic and is used to induce panic attacks in studies of anxiety. ${ }^{120}$ The $\mathrm{C}$ terminal sequence in these peptides is common to the gastrin peptide hormones as mentioned in Section 6.

Glutathione is tripeptide (L- $\gamma$-glutamyl-L-cysteinylglycine, H-isoGlu-Cys-Gly-OH) denoted GSH, in which there is a gamma peptide link between the glutamic acid side chain and cysteine. It is an antioxidant, the thiol group serving as a reducing agent in vivo, disrupting disulfide bonds in proteins to yield free cysteine groups. ${ }^{138,374}$ It is involved in many biological processes including metabolism, protein and DNA synthesis and protection of cells. ${ }^{138}$

The dipeptide L-carnosine ( $\beta$-alanine-histidine, $\beta \mathrm{AH}$ ) has a range of biological activities. ${ }^{76,140,375-376}$ In particular it has antioxidant properties for carbohydrates 
(anti-glycation) ${ }^{377-378}$ and lipids (anti-lipoxidation). ${ }^{139}$ The presence of the $\beta$-alanine $(\beta \mathrm{AH})$ residue is implicated in these roles, since it can react directly with oxidized carbohydrates and lipids. ${ }^{379}$ The histidine $(\mathrm{H})$ residue is able to bind to transition metal ions. Histidine-containing dipeptides such as L-carnosine are present in the mammalian brain within neuroglia and certain types of neurons. ${ }^{380}$ Carnosine is present in muscle and nerve tissue, as well as the brain. ${ }^{76,140,375-376}$ Carnosine has been proposed as a treatment for Alzheimer's disease, ${ }^{380}$ and it has also been shown to delay senescence of cultured cells, ${ }^{381}$ which has been ascribed to the antioxidant properties of the peptide. ${ }^{378}$

Thymopentin, also known as TP-5, is a pentapeptide fragment (RLNVY) corresponding to residues 32 to 36 of human thymopoetin (a.k.a. lamina-associated polypeptide 2). ${ }^{382-383}$ Thymopentin is an immunostimulant, used for example in the treatment of dermatitis. ${ }^{383}$ Many other medical applications involving immunomodulation have been summarized. ${ }^{384}$ Splenopentin with sequence RLGVY is a related immunomodulation peptide. ${ }^{384}$ Cycloinopeptide is a cyclic nonapeptide cyclo-(Pro-Pro-Phe-Phe-Leu-Ile-Ile-Leu-Val) extracted from linseed oil ${ }^{385}$ with activity as an immunosuppressant. ${ }^{386}$

Cyclosporin or cyclosporine (Fig.16) is a cyclic 11-residue peptide/peptoid hybrid with sequence cyclo[AbuSar(N(Me)L)V(N(Me)L)Aa(N(Me)L)(N(Me)L)(N(Me)V)(N(Me)Bmt(E))]. ${ }^{143,387}$ Peptoids are $N$-substituted analogues of peptides, and here Sar denotes sarcosine, $N$-methylglycine, Abu denotes aminobutric acid and $\mathrm{Bmt}(\mathrm{E})$ denotes (E)-but-2-enyl threonine. Cyclosporin is a powerful immunosuppressant, working on T-lymphocytes. ${ }^{141-142,387}$ It also displays antifungal and anti-inflammatory 
properties. It is an extract from soil fungus and is synthesized by a nonribosomal synthetase. $^{142}$

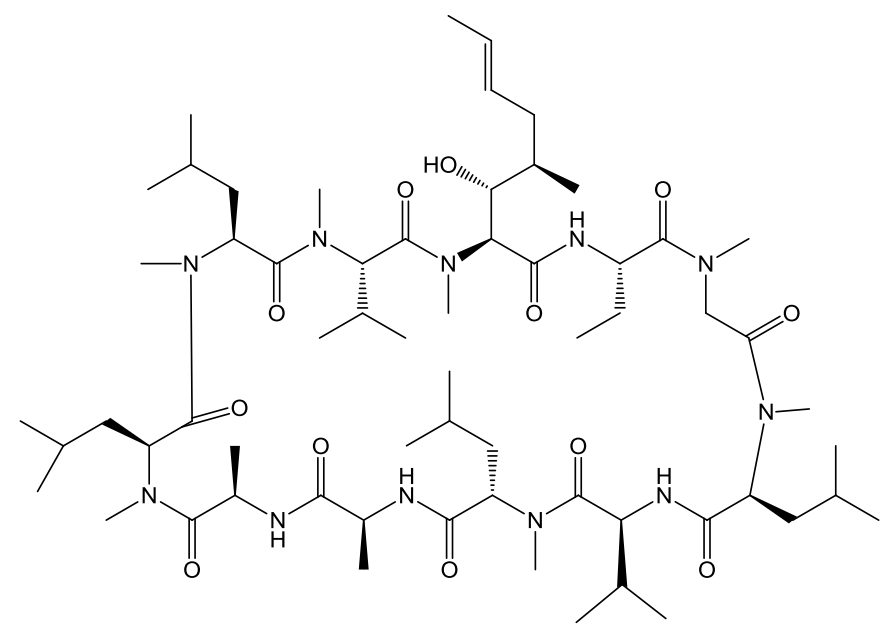

Fig.16. Molecular structure of cyclosporin.

\section{Protein Tags}

Recombinant production of proteins is becoming a ubiquitous technology. Peptide tags enable isolation via affinity chromatography of expressed proteins cleaved at defined positions (Fig.17). Short peptide cleavage sequences have advantages compared to longer tags in minimizing the effect on the processing and conformation of the expressed protein.

(a)

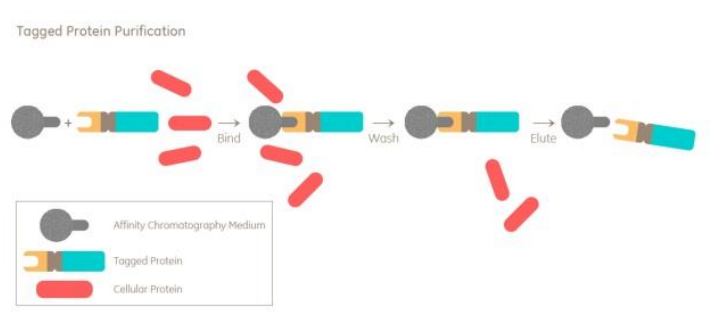

(b)

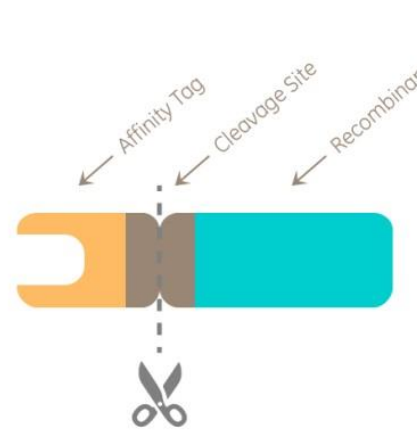


Fig.17. (a) Affinity chromatography purification of recombinant proteins tagged with an affinity peptide domain. (b) Cleavage done on column or after elution. ${ }^{388}$

The oligo-or poly-histidine tag (e.g. hexa-histidine), developed by researchers at Roche, ${ }^{145-146}$ is widely used in the affinity purification of expressed recombinant proteins. ${ }^{389}$ The protein to be labelled is engineered to incorporate $\mathrm{N}$ - or C-terminal histidine repeats. A common system employs a hexahistidine tag along with a metal chelate among which the nitrilotriacetic acid (NTA)/ $/ \mathrm{Ni}^{2+}$ system is widely used. Since nickel ions are hexa-coordinated and four electrons are used in binding to NTA, two electrons are available to bind hexahistidine tags. This interaction has high affinity and selectivity. ${ }^{390-392}$ Other oligopeptides including oligo(arginine) (developed in $1984^{144}$ ), oligo(aspartic acid) and oligo(phenylalanine) have also been used as fusion tags. ${ }^{33}$ Some of these sequences can adversely influence the tertiary structure of proteins to which they are attached. ${ }^{34}$

The Strep-tag II peptide (WSHPQFEK) is an affinity sequence for use in streptavidin or modified streptavidin columns. ${ }^{34,147-148}$ The myc or c-myc tag (derived from a transcription factor regulator gene) corresponds to peptide EQKLISEEDL. ${ }^{34,149}$ Use of this tag is based on a known anti-c-myc antibody used as an immunochemical agent in cell biology. ${ }^{393}$

A range of other peptide tags, including commercially licensed technologies, has been developed including FlagTag (sequence DYKDDDDK) which incorporates a cleavage site for enterokinases (a class of digestive enzyme) ${ }^{33,}{ }^{150}$ It is used in immunoaffinity chromatography. The Spytag peptide with sequence 
AHIVMVDAYKPTK ${ }^{394}$ is designed to bind to the Spycatcher protein via amide bond formation. ${ }^{395}$

Derivatives of the cyclic peptide phalloidin (Fig.18) are used as fluorescent tags.

Phalloidin is a bicyclic heptapeptide, originally isolated from the death cap mushroom. ${ }^{396}$ It is used in fluorescent stains in cell viability studies because it binds to (and stabilizes) actin (in its filamentous form), ${ }^{396-397}$ which is an essential component of the cytoskeleton.

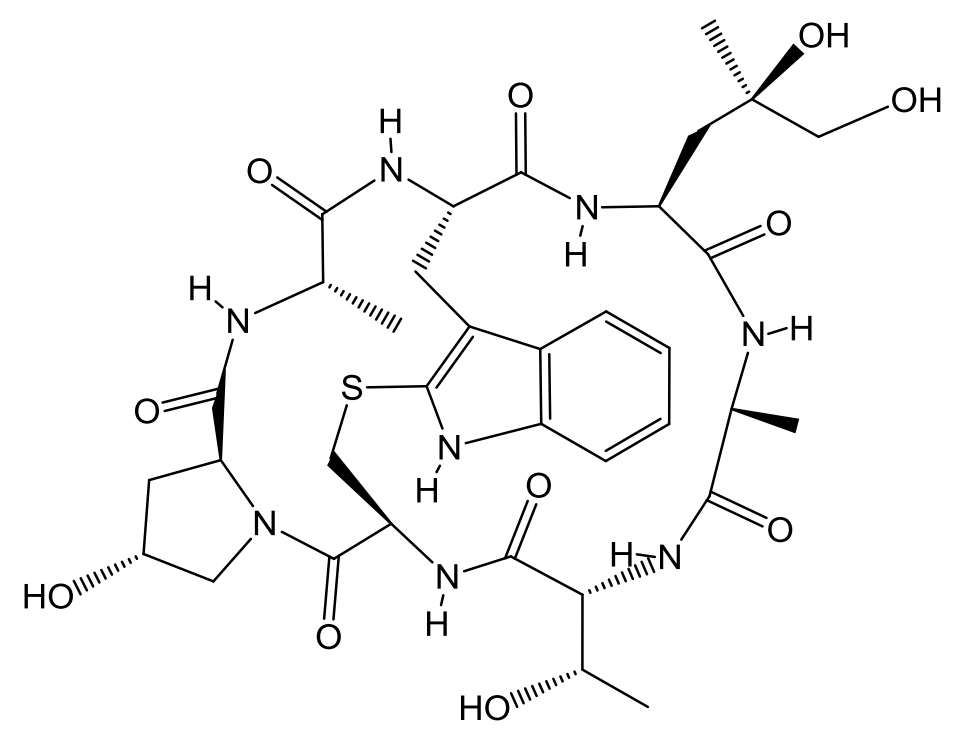

Fig.18. Molecular structure of phalloidin. 
Lists of other fusion tags for recombinant protein production are available with detail on the purification systems and the advantages and disadvantages of particular systems. ${ }^{33-35,37}$

\section{Anti-Cancer Peptides}

Anticancer "tumor-homing" peptides have been discussed in Section 4. Here several types of cyclic peptide with anticancer activity are discussed.

Bleomycins are important anti-cancer agents. The molecules are peptide derivatives (Fig.19), being glycosylated peptide-polyketides containing two thiazolines resulting from cyclization of cysteine residues. ${ }^{151-155}$ The bleomycins are non-ribosomal peptides produced by the bacterium Streptomyces verticillus. ${ }^{151}$ They act by cleaving DNA strands. ${ }^{154,398}$ Bleomycins have been classed as "metalloantibiotics" because they were originally discovered to be antibiotics and their activity (binding and cleaving DNA molecules) depends on the presence of ions (especially $\mathrm{Fe}^{2+}$ ). ${ }^{89}$

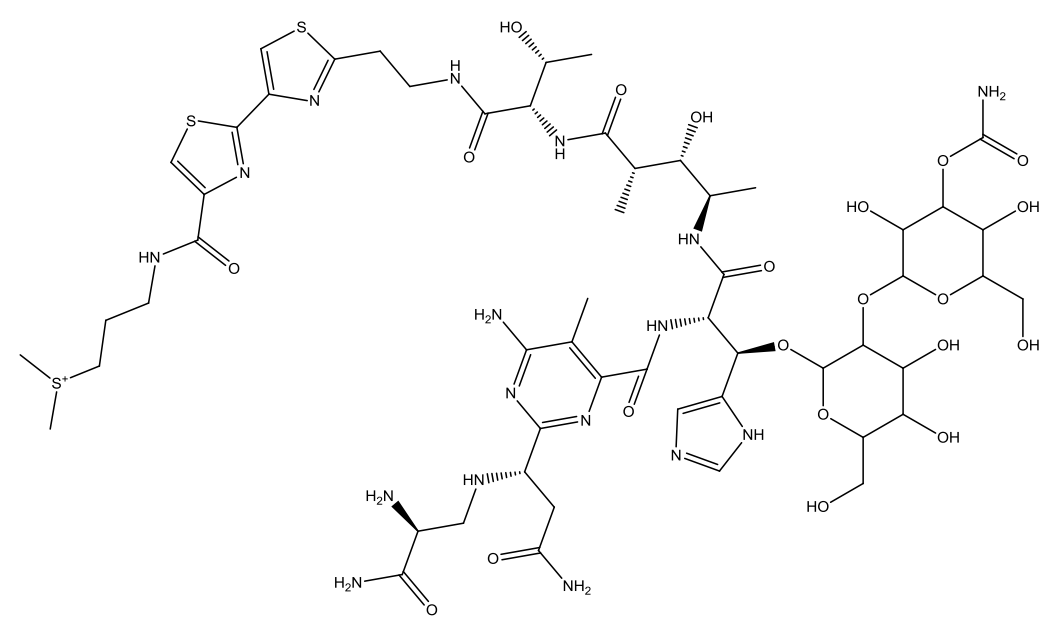


Fig.19. Molecular structure of bleomycin $\mathrm{A}_{2}{ }^{154}$

Dolastatin 10 (Fig.20) is a short peptide containing five residues with an interesting selection of non-proteogenic amino acids. ${ }^{156-157}$ This peptide, originally isolated from a marine mollusk, has potential anticancer activity, as it has an antimitotic activity, inhibiting tubulin polymerization. ${ }^{157}$ Dolastatin 10 is one example from a diverse range of marine natural products with anti-cancer properties resulting from microtubule growth inhibition, ${ }^{17,399-400}$ such as hemiasterlins which are short linear peptide derivatives obtained from a marine sponge..$^{401}$

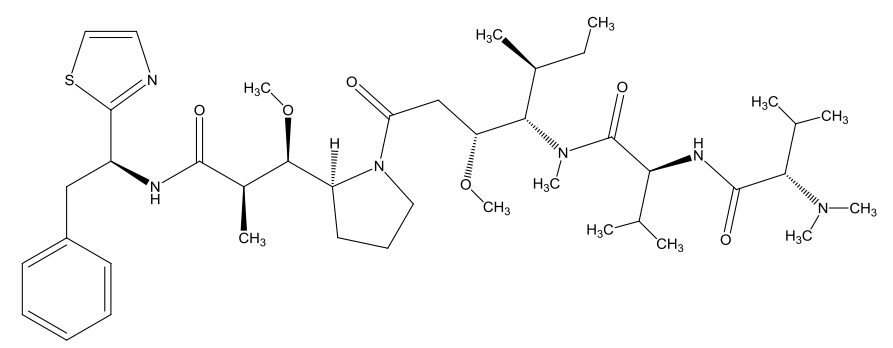

Fig.20. Molecular structure of dolastatin 10.

Apicidin (Fig.21a) is a cyclic tetrapeptide which is a histone deacetylase inhibitor (HDAC). ${ }^{158-160}$ It was isolated as a fungal metabolite. ${ }^{402}$ It has potential anticancer activity $^{158-160}$ and acts against protozoan parasites such as Plasmodium (malaria infective agent), ${ }^{402}$ among other applications. Chlamydocin is a related cyclic tetrapeptide ${ }^{403}$ obtained from origins as a fungal natural product. ${ }^{38,404}$ It is reported to inhibit the growth of tumor cells. ${ }^{405-406}$ Romidepsin (Fig.21b) is a bicyclic depsipeptide (isolated from a soil bacterium ${ }^{161}$ ) which is also a histone deacetylase inhibitor with pronounced anticancer activity against several types of lymphoma. ${ }^{162-}$ ${ }^{166}$ Largazole (Fig.20c) also belongs to the class of cyclic depsipeptide natural 
products with HDAC anticancer activity. ${ }^{167-168}$ A variety of other, less well studied cyclic peptides with anticancer activity are covered in a recent review. ${ }^{38}$

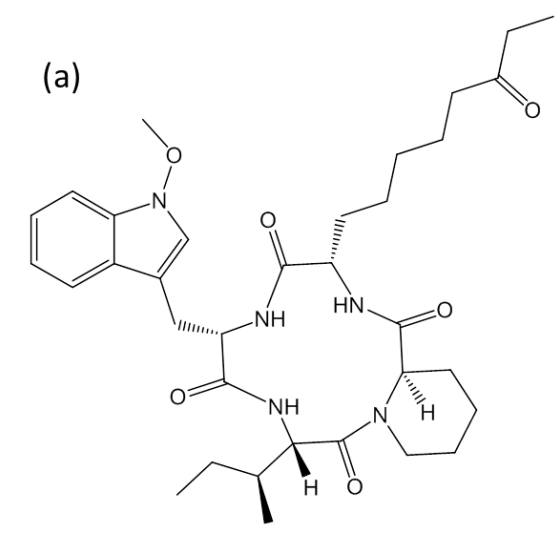

(b)

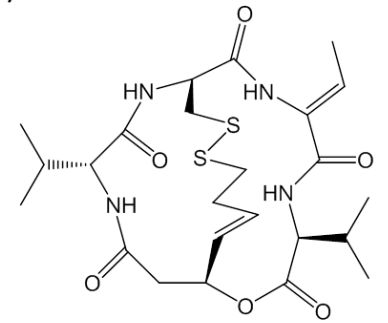

(c)

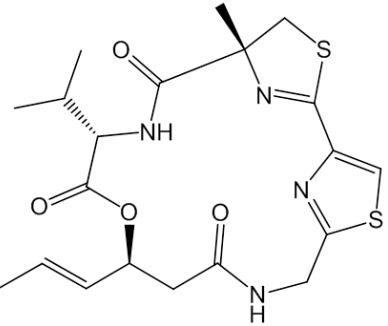

Fig.21. Molecular structures of (a) apicidin, ${ }^{402-403}$ (b) romidepsin, ${ }^{38,161}$ (c) largazole. ${ }^{168,407}$

\section{Miscellaneous Peptides}

Protein-protein interactions can occur through recognition of short peptide sequences. This has been particularly extensively studied for signaling protein complexes such as the Src-homology domains $\mathrm{SH} 2$ and $\mathrm{SH} 3 .^{408-409} \mathrm{SH} 2$ and $\mathrm{SH} 3$ domains regulate the activity of Src tyrosine kinases. SH2 domains recognize phosphorylated tyrosines in specific sequences (see e.g. ref. $^{410}$ ). SH3 is a proline-recognition domain which has affinity for particular proline sequences such as the consensus motif PXXP. ${ }^{410-412}$ Peptides have also been designed to inhibit protein interactions. ${ }^{413}$ As these proteins 
involve recognition of sequences within larger proteins, and not short peptides per se, this fascinating subject is not considered further here.

The artificial sweetener aspartame is the dipeptide ester DF-OMe. ${ }^{169,414}$ Since it contains phenylalanine, products containing this peptide are labelled as such to alert those suffering from the inherited condition phenylketonuria in which phenylalanine metabolism is disrupted. For this and other reasons, the safety of aspartame has been investigated in considerable detail. ${ }^{170,415}$

A range of peptides have been obtained by screening methods that bind to specific inorganic materials, nanoparticles, metals and metal oxides etc. The peptides are of interest for peptide functionalization of nanoparticles (for diagnostic or therapeutic applications for example), heavy metal remediation, templated synthesis etc. These sequences tend to be rather specific to individual studies or a particular application, and are not considered further here. Metal ions are also proposed to play important roles in the progression of amyloidosis for example of Amyloid $\beta \cdot{ }^{345}$ Peptides may be designed to mimic larger metalloproteins. ${ }^{416}$ Reviews on the topic of peptides binding to inorganic materials/peptide immobilization on inorganic materials are available. ${ }^{417}$ 418

Another important area where small peptides have promise is the field of artificial enzyme where the aim is to create an active hydrophobic pocket mimicking that of a folded protein, but using a short peptide. Short histidine-bearing peptides have attracted particular attention in the development of peptide-based catalysis. For example, the tripeptide Hff is a thermoreversible hydrogelator which is able to 
catalyse the hydrolysis of an ester. ${ }^{419}$ Similarly, Fmoc-FFH self-assembles into nanotubes and is able to catalyse ester hydrolysis. ${ }^{420}$ An FF peptide with N-terminal ferrocene unit is able to form oil-in-water nanoemulsions and has redox activity. ${ }^{421}$ In another example, the tripeptide glutathione (section 9) is able to form iron-sulfur clusters in the presence of UV light, this mimicking the active site of ferrodoxins. ${ }^{422}$ The self-assembly of small peptides into defined nanostructures may itself lead to enhanced activity in catalysis, since the peptide is presented at high density. In one example, $(\mathrm{EF})_{\mathrm{n}}$ and $(\mathrm{FE})_{\mathrm{n}}$ lipopeptides capped with $\mathrm{N}$-terminal proline are able to catalyse an aldol reaction when aggregated (as fibrils) but this does not occur with unaggreated homologues (with much shorter C-terminal alkyl units). ${ }^{423}$

\section{Conclusions and Discussion}

Combining different functionalities into a peptide sequence is not as straightforward as just linking peptide sequences in a linear fashion due to the multiplicity of intermolecular interactions at play including electrostatic forces, van der Waals forces, hydrogen bonding, aromatic stacking interactions etc. This is exemplified by the discussion in Section 3 about RGD and the synergy PHSRN domain. A defined spacing (of amino acids non-functional for integrin binding in this case) between these two motifs is needed as a minimal element of a functional conjugate. In other cases the design may need more than control of just spacing, or it may simply not be possible to create a conjugate when the functional domains are incompatible or antagonistic. Lipidation is a strategy to create assemblies of a hydrophilic peptide domain presented at high density on the surface of nanofibrils, which can exhibit enhanced bioactivity compared to the unconjugated peptide. ${ }^{424}$ 
Computational screening (e.g. the impressive first analysis of aggregation propensity of all tripeptides ${ }^{365}$ ) is a powerful method which could be developed to screen other properties of di- and tri-peptides but it is of limited use for larger peptides where unfortunately as yet, ad hoc design rules, serendipity or bioinspiration are required to discover novel short peptides with interesting functionality. This review has given an overview of some examples. Unfortunately an overarching set of principles able to account for why a particular peptide has optimal or excellent desired activity are unlikely ever to be available since the parameter space is so vast (not just due to the $20^{\mathrm{n}}$ hypothetical sequences from the 20 proteinogenic amino acids but all the other variables associated with aggregation including solution conditions etc) and the number of applications is so large. This is, in part, what makes this such a fascinating research field. In particular cases, design rules are available. For instance it is now well established that lysis-causing antimicrobial peptides require cationic arginine residues in their sequence, whilst ion channel forming cyclic peptides have an alternating D/L amino acid design. ${ }^{425}$ In other cases, such as amyloid peptides, tools based on (peptide/amino acid) property databases are available (e.g. WALTZ, Zyggregator ${ }^{426}$ or TANGO $^{427-428}$ aggregation predictors) to predict aggregation propensity however this often only provides post hoc rationalization.

There are many promising directions in the application of novel peptides in fields such as tissue engineering and biomaterials development, and the creation of enzyme mimics. Some examples of research to date in these fields have been provided but there is great scope for further development. Of course, there is also immense interest 
in small peptide, peptide-based and peptide-inspired therapeutics for a range of conditions and this field is likely to see exciting discoveries in the near future.

\section{Acknowledgements}

IWH is PI on the EPSRC Platform Grant "Nanostructured Materials for Healthcare" (ref. EP/L020599/1). I am grateful to team members and collaborators for their essential contributions over the years.

\section{Biography}

Professor Ian W. Hamley is Diamond Professor of Physical Chemistry at the University of Reading (UK). He obtained his $\mathrm{PhD}$ at the University of Southampton (UK) and undertook postdoc positions in Amsterdam, The Netherlands (AMOLF) and the University of Minnesota, USA. He returned to the UK in 1993 to take up a lectureship at the University of Durham (1993-5) then moved to the University of Leeds (1995-2005) where he was promoted in 2003 to Professor. He moved to the University of Reading in 2005 to take up a joint appointment with Diamond Light Source, the UK synchrotron facility (2005-2010). He has more than 20 years' experience of research on different types of soft materials, including peptides, polymers, liquid crystals and surfactants. He received a Royal Society-Wolfson Research Merit Award in 2011, the Royal Society of Chemistry Peter Day Award for Materials Chemistry (2016) and the MacroGroup UK Medal (2017). His research programme focuses on the self-assembly of peptide materials and its relationship to bioactivity. He has supervised more than forty postdoctoral and postgraduate researchers and has published over 370 papers and several edited and authored books.

\section{References}

(1) Place, E. S.; Evans, N. D.; Stevens, M. M., Complexity in Biomaterials for

Tissue Engineering. Nature Mater. 2009, 8, 457-470. 
(2) Sengupta, D.; Heilshorn, S. C., Protein-Engineered Biomaterials: Highly Tunable Tissue Engineering Scaffolds. Tissue Eng. Part B-Rev. 2010, 16, 285293.

(3) DiMarco, R. L.; Heilshorn, S. C., Multifunctional Materials through Modular Protein Engineering. Adv. Mater. 2012, 24, 3923-3940.

(4) Ruoslahti, E., RGD and Other Recognition Sequences for Integrins. Annu. Rev. Cell Dev. Biol. 1996, 12, 697-715.

(5) Zorko, M.; Langel, U., Cell-Penetrating Peptides: Mechanism and Kinetics of Cargo Delivery. Adv. Drug Del. Rev. 2005, 57, 529-545.

(6) Fonseca, S. B.; Pereira, M. P.; Kelley, S. O., Recent Advances in the Use of Cell-Penetrating Peptides for Medical and Biological Applications. Adv. Drug Del. Rev. 2009, 61, 953-964.

(7) Hancock, R. E. W.; Chapple, D. S., Peptide Antibiotics. Antimicrob. Agents Chemother. 1999, 43, 1317-1323.

(8) Hancock, R. E. W.; Diamond, G., The Role of Cationic Antimicrobial Peptides in Innate Host Defences. Trends Microbiol. 2000, 8, 402-410.

(9) Boman, H. G., Antibacterial Peptides: Basic Facts and Emerging Concepts. $J$. Internal Med. 2003, 254, 197-215.

(10) Jenssen, H.; Hamill, P.; Hancock, R. E. W., Peptide Antimicrobial Agents. Clin. Microbiol. Rev. 2006, 19, 491-511.

(11) Hancock, R. E. W.; Sahl, H. G., Antimicrobial and Host-Defense Peptides as New Anti-Infective Therapeutic Strategies. Nature Biotech. 2006, 24, 15511557. 
(12) Chan, D. I.; Prenner, E. J.; Vogel, H. J., Tryptophan- and Arginine-Rich Antimicrobial Peptides: Structures and Mechanisms of Action. Biochim. Biophys. Acta - Biomembranes 2006, 1758, 1184-1202.

(13) Zasloff, M., Antimicrobial Peptides of Multicellular Organisms. Nature 2002, $415,389-395$.

(14) Tossi, A.; Sandri, L.; Giangaspero, A., Amphipathic, $\alpha$-Helical Antimicrobial Peptides. Biopolymers 2000, 55, 4-30.

(15) Tager, H. S.; Steiner, D. F., Peptide Hormones. Annu. Rev. Biochem. 1974, 43, $509-538$.

(16) Huda, M. S. B.; Wilding, J. P. H.; Pinkney, J. H., Gut Peptides and the Regulation of Appetite. Obes. Rev. 2006, 7, 163-182.

(17) Gentilucci, L.; Tolomelli, A.; Squassabia, F., Peptides and Peptidomimetics in Medicine, Surgery and Biotechnology. Curr. Med. Chem. 2006, 13, 2449-2466.

(18) Rehfeld, J. F.; Bundgaard, J. R., Cellular Peptide Hormone Synthesis and Secretory Pathways. Springer-Verlag: Berlin, 2010.

(19) Hutchinson, J. A.; Burholt, S.; Hamley, I. W., Peptide Hormones and Lipopeptides: From Self-Assembly to Therapeutic Applications. J. Pept. Sci. 2017, 23, 82-94.

(20) Soto, C., Unfolding the Role of Protein Misfolding in Neurodegenerative Diseases. Nat. Rev. Neurosci. 2003, 4, 49-60.

(21) Selkoe, D. J., Folding Proteins in Fatal Ways. Nature 2003, 426, 900-904.

(22) Rochet, J. C.; Lansbury, P. T., Amyloid Fibrillogenesis: Themes and Variations. Curr. Op. Struct. Biol. 2000, 10, 60-68.

(23) Dobson, C. M., Protein Folding and Misfolding. Nature 2003, 426, 884-890. 
(24) Ross, C. A.; Poirier, M. A., Protein Aggregation and Neurodegenerative Disease. Nature Med. 2004, 10, S10-S17.

(25) Chiti, F.; Dobson, C. M., Protein Misfolding, Functional Amyloid, and Human Disease. Annu. Rev. Biochem. 2006, 75, 333-366.

(26) Hamley, I. W., Peptide Fibrillisation. Angew. Chem. Int. Ed. Engl. 2007, 46, $8128-8147$.

(27) Fowler, D. M.; Koulov, A. V.; Balch, W. E.; Kelly, J. W., Functional Amyloid from Bacteria to Humans. Trends Biochem. Sci. 2007, 32, 217-224.

(28) Eisenberg, D.; Jucker, M., The Amyloid State of Proteins in Human Diseases. Cell 2012, 148, 1188-1203.

(29) Schwartz, M. W.; Woods, S. C.; Porte, D.; Seeley, R. J.; Baskin, D. G., Central Nervous System Control of Food Intake. Nature 2000, 404, 661-671.

(30) Donaldson, Z. R.; Young, L. J., Oxytocin, Vasopressin, and the Neurogenetics of Sociality. Science 2008, 322, 900-904.

(31) Morley, J. E., Neuropeptide Regulation of Appetite and Weight. Endocr. Rev. 1987, $8,256-287$.

(32) Meyer-Lindenberg, A.; Domes, G.; Kirsch, P.; Heinrichs, M., Oxytocin and Vasopressin in the Human Brain: Social Neuropeptides for Translational Medicine. Nat. Rev. Neurosci. 2011, 12, 524-538.

(33) Einhauer, A.; Jungbauer, A., The Flag ${ }^{\mathrm{TM}}$ Peptide, a Versatile Fusion Tag for the Purification of Recombinant Proteins. J. Biochem. Biophys. Methods 2001, 49, 455-465.

(34) Terpe, K., Overview of Tag Protein Fusions: From Molecular and Biochemical Fundamentals to Commercial Systems. Appl. Microbiol. Biotech. 2003, 60, 523533. 
(35) Waugh, D. S., Making the Most of Affinity Tags. Trends Biotech. 2005, 23, 316-320.

(36) Arnau, J.; Lauritzen, C.; Petersen, G. E.; Pedersen, J., Current Strategies for the Use of Affinity Tags and Tag Removal for the Purification of Recombinant Proteins. Protein Expr. Purif. 2006, 48, 1-13.

(37) Kimple, M. E.; Brill, A. L.; Pasker, R. L., Overview of Affinity Tags for Protein Purification. Curr. Prot. Prot. Sci. 2013, 73, Unit 9.9.

(38) Nielsen D, S.; Shepherd, N. E.; Wu, X.; Lucke, A. J.; Stoermer, M. J.; Fairlie, D. P., Orally Absorbed Cyclic Peptides. Chem. Rev. 2017, 117, 8094-8128.

(39) Ruoslahti, E.; Pierschbacher, M. D., Arg-Gly-Asp - a Versatile Cell Recognition Signal. Cell 1986, 44, 517-518.

(40) Ruoslahti, E.; Pierschbacher, M. D., New Perspectives in Cell-Adhesion - RGD and Integrins. Science 1987, 238, 491-497.

(41) Hynes, R. O., Integrins - Versatility, Modulation, and Signaling in CellAdhesion. Cell 1992, 69, 11-25.

(42) Healy, J. M.; Murayama, O.; Maeda, T.; Yoshino, K.; Sekiguchi, K.; Kikuchi, M., Peptide Ligands for Integrin $\alpha_{v} \beta_{3}$ Selected from Random Phage Display Libraries. Biochemistry 1995, 34, 3948-3955.

(43) Hubbell, J. A., Biomaterials in Tissue Engineering. Bio-Technology 1995, 13, $565-576$.

(44) Tirrell, M.; Kokkoli, E.; Biesalski, M., The Role of Surface Science in Bioengineered Materials. Surface Sci. 2002, 500, 61-83.

(45) Dennis, M. S.; Henzel, W. J.; Pitti, R. M.; Lipari, M. T.; Napier, M. A.; Deisher, T. A.; Bunting, S.; Lazarus, R. A., Platelet Glycoprotein-IIb-IIIa Protein 
Antagonists from Snake-Venoms - Evidence for a Family of PlateletAggregation Inhibitors. Proc. Nat. Acad. Sci USA 1990, 87, 2471-2475.

(46) Topol, E. J.; Byzova, T. V.; Plow, E. F., Platelet GPIIb-IIIa Blockers. Lancet 1999, 353, 227-231.

(47) Millard, M.; Odde, S.; Neamati, N., Integrin Targeted Therapeutics. Theranostics 2011, 1, 154-188.

(48) Aota, S.; Nomizu, M.; Yamada, K. M., The Short Amino-Acid-Sequence ProHis-Ser-Arg-Asn in Human Fibronectin Enhances Cell-Adhesive Function. $J$. Biol. Chem. 1994, 269, 24756-24761.

(49) Mould, A. P.; Komoriya, A.; Yamada, K. M.; Humphries, M. J., The CS5 Peptide is a Second Site in the IIICS Region of Fibronectin Recognized by the Integrin $\alpha_{4} \beta_{1}$. J. Biol. Chem. 1991, 266, 3579-3585.

(50) Akiyama, S. K.; Olden, K.; Yamada, K. M., Fibronectin and Integrins in Invasion and Metastasis. Cancer Metastasis Rev. 1995, 14, 173-189.

(51) Graf, J.; Iwamoto, Y.; Sasaki, M.; Martin, G. R.; Kleinman, H. K.; Robey, F. A.; Yamada, Y., Identification of an Amino-Acid-Sequence in Laminin Mediating Cell Attachment, Chemotaxis, and Receptor-Binding. Cell 1987, 48, 989-996.

(52) Sasaki, M.; Yamada, Y., The Laminin B2 Chain has a Multidomain Structure Homologous to the B1 Chain. J. Biol. Chem. 1987, 262, 17111-17117.

(53) Tashiro, K.; Sephel, G. C.; Weeks, B.; Sasaki, M.; Martin, G. R.; Kleinman, H. K.; Yamada, Y., A Synthetic Peptide Containing the IKVAV Sequence from the $\alpha$-Chain of Laminin Mediates Cell Attachment, Migration, and Neurite Outgrowth. J. Biol. Chem. 1989, 264, 16174-16182. 
(54) Staatz, W. D.; Fok, K. F.; Zutter, M. M.; Adams, S. P.; Rodriguez, B. A.; Santoro, S. A., Identification of a Tetrapeptide Recognition Sequence for the $\alpha_{2} \beta_{1}$ Integrin in Collagen. J. Biol. Chem. 1991, 266, 7363-7367.

(55) Shin, H.; Jo, S.; Mikos, A. G., Biomimetic Materials for Tissue Engineering. Biomater. 2003, 24, 4353-4364.

(56) Nelson, M.; Balasundaram, G.; Webster, T. J., Increased Osteloblast Adhesion on Nanoparticulate Crystalline Hydroxyapatite Functionalized with KRSR. Int. J. Nanomed. 2006, 1, 339-349.

(57) Dee, K. C.; Andersen, T. T.; Bizios, R., Design and Function of Novel Osteoblast-Adhesive Peptides for Chemical Modification of Biomaterials. $J$. Biomed. Mater. Res. 1998, 40, 371-377.

(58) Emsley, J.; Knight, C. G.; Farndale, R. W.; Barnes, M. J.; Liddington, R. C., Structural Basis of Collagen Recognition by Integrin $\alpha_{2} \beta_{1}$. Cell 2000, 101, 4756.

(59) Barczyk, M.; Carracedo, S.; Gullberg, D., Integrins. Cell Tissue Res. 2010, 339, 269-280.

(60) Knight, C. G.; Morton, L. F.; Peachey, A. R.; Tuckwell, D. S.; Farndale, R. W.; Barnes, M. J., The Collagen-Binding A-Domains of Integrins $\alpha_{1} \beta_{1}$ and $\alpha_{2} \beta_{1}$ Recognize the Same Specific Amino Acid Sequence, GFOGER, in Native (Triple-Helical) Collagens. J. Biol. Chem. 2000, 275, 35-40.

(61) Sweeney, S. M.; Orgel, J. P.; Fertala, A.; McAuliffe, J. D.; Turner, K. R.; Di Lullo, G. A.; Chen, S.; Antipova, O.; Perumal, S.; Ala-Kokko, L., et al., Candidate Cell and Matrix Interaction Domains on the Collagen Fibril, the Predominant Protein of Vertebrates. J. Biol. Chem. 2008, 283, 21187-21197. 
(62) Kaplan, D.; Adams, W. W.; Farmer, B.; Viney, C., Silk Polymers. Materials Science and Biotechnology. Washington, D.C.: ACS, 1994.

(63) Voet, D.; Voet, J. G., Biochemistry. John Wiley: New York, 1995.

(64) Creighton, C. J.; Du, Y. M.; Reitz, A. B., Design, Synthesis, and Conformational Analysis of Eight-Membered Cyclic Peptidomimetics Prepared Using Ring Closing Metathesis. Bioorg. Med. Chem. 2004, 12, 4375-4385.

(65) Branden, C.; Tooze, J., Introduction to Protein Structure. Garland Publishing: New York, 1999.

(66) Urry, D. W., Physical Chemistry of Biological Free Energy Transduction as Demonstrated by Elastic Protein-Based Polymers. J. Phys. Chem. B 1997, 101, 11007-11028.

(67) Meyer, D. E.; Chilkoti, A., Quantification of the Effects of Chain Length and Concentration on the Thermal Behavior of Elastin-Like Polypeptides.

Biomacromol. 2004, 5, 846-851.

(68) Elvin, C. M.; Carr, A. G.; Huson, M. G.; Maxwell, J. M.; Pearson, R. D.; Vuocolo, T.; Liyou, N. E.; Wong, D. C. C.; Merritt, D. J.; Dixon, N. E., Synthesis and Properties of Crosslinked Recombinant Pro-Resilin. Nature 2005, 437, 999-1002.

(69) Li, L.; Kiick, K. L., Resilin-Based Materials for Biomedical Applications. ACS Macro Lett. 2013, 2, 635-640.

(70) Su, R. S. C.; Kim, Y.; Liu, J. C., Resilin: Protein-Based Elastomeric Biomaterials. Acta Biomater. 2014, 10, 1601-1611.

(71) Ardell, D. H.; Andersen, S. O., Tentative Identification of a Resilin Gene in Drosophila Melanogaster. Insect Biochem. Mol. Biol. 2001, 31, 965-970. 
(72) Frankel, A. D.; Pabo, C. O., Cellular Uptake of the Tat Protein from Human Immunodeficiency Virus. Cell 1988, 55, 1189-1193.

(73) Green, M.; Loewenstein, P. M., Autonomous Functional Domains of Chemically Synthesized Human Immunodeficiency Virus Tat Trans-Activator Protein. Cell 1988, 55, 1179-1188.

(74) Vives, E.; Brodin, P.; Lebleu, B., A Truncated HIV-1 TAT Protein Basic Domain Rapidly Translocates through the Plasma Membrane and Accumulates in the Cell Nucleus. J. Biol. Chem. 1997, 272, 16010-16017.

(75) Schwarze, S. R.; Hruska, K. A.; Dowdy, S. F., Protein Transduction: Unrestricted Delivery into All Cells? Trends Cell Biol. 2000, 10, 290-295.

(76) Gariballa, S. E.; Sinclair, A. J., Carnosine: Physiological Properties and Therapeutic Potential. Age and Aging 2000, 29, 207-210.

(77) Ho, A.; Schwarze, S. R.; Mermelstein, S. J.; Waksman, G.; Dowdy, S. F., Synthetic Protein Transduction Domains: Enhanced Transduction Potential in Vitro and in Vivo. Cancer Res. 2001, 61, 474-477.

(78) Stanzl, E. G.; Trantow, B. M.; Vargas, J. R.; Wender, P. A., Fifteen Years of Cell-Penetrating Guanidinium-Rich Molecular Transporters: Basic Science, Research Tools, and Clinical Applications. Acc. Chem. Res. 2013, 46, 29442954.

(79) Derossi, D.; Joliot, A. H.; Chassaing, G.; Prochiantz, A., The Third Helix of the Antennapedia Homeodomain Translocates through Biological-Membranes. $J$. Biol. Chem. 1994, 269, 10444-10450.

(80) Derossi, D.; Chassaing, G.; Prochiantz, A., Trojan Peptides: The Penetratin System for Intracellular Delivery. Trends Cell Biol. 1998, 8, 84-87. 
(81) Prochiantz, A., Homeodomain-Derived Peptides - in and out of the Cells. In Anticancer Molecules: Structure, Function, and Design, Maruta, H., Ed. New York Acad Sciences: New York, 1999; Vol. 886, pp 172-179.

(82) Jing, W.; Hunter, H. N.; Hagel, J.; Vogel, H. J., The Structure of the Antimicrobial Peptide Ac-RRWWRF- $\mathrm{NH}_{2}$ Bound to Micelles and Its Interactions with Phospholipid Bilayers. J. Pept. Res. 2003, 61, 219-229.

(83) Peypoux, F.; Bonmatin, J. M.; Wallach, J., Recent Trends in the Biochemistry of Surfactin. Appl. Microbiol. Biotech. 1999, 51, 553-563.

(84) Desai, J. D.; Banat, I. M., Microbial Production of Surfactants and Their Commercial Potential. Microbiol. Molec. Biol. Rev. 1997, 61, 47-64.

(85) Mulligan, C. N., Environmental Applications for Biosurfactants. Environ. Pollution 2005, 133, 183-198.

(86) Tsuji, K.; Robertson, J. H., Improved High-Performance LiquidChromatographic Method for Polypeptide Antibiotics and Its Application to Study Effects of Treatments to Reduce Microbial Levels in Bacitracin Powder. J. Chromatog. 1975, 112, 663-672.

(87) Bell, R. G., Preparative High-Performance Liquid-Chromatographic Separation and Isolation of Bacitracin Components and Their Relationship to Microbiological Activity. J. Chromatog. 1992, 590, 163-168.

(88) Newton, G. G. F.; Abraham, E. P., Some Properties of the Bacitracin Polypeptides. Biochem. J. 1953, 53, 597-604.

(89) Ming, L. J., Structure and Function of "Metalloantibiotics". Med. Res. Rev. 2003, 23, 697-762. 
(90) Kwa, A.; Kosiakou, S. K.; Tam, V. H.; Falagas, M. E., Polymyxin B:

Similarities to and Differences from Colistin (Polymyxin E). Expert Rev. AntiInfect. Ther. 2007, 5, 811-821.

(91) Landman, D.; Georgescu, C.; Martin, D. A.; Quale, J., Polymyxins Revisited. Clin. Microbiol. Rev. 2008, 21, 449-465.

(92) Nakamura, T.; Furunaka, H.; Miyata, T.; Tokunaga, F.; Muta, T.; Iwanaga, S.; Niwa, M.; Takao, T.; Shimonishi, Y., Tachyplesin, a Class of Antimicrobial Peptide from the Hemocytes of the Horseshoe-Crab (Tachypleus-Tridentatus) Isolation and Chemical-Structure. J. Biol. Chem. 1988, 263, 16709-16713.

(93) Kokryakov, V. N.; Harwig, S. S. L.; Panyutich, E. A.; Shevchenko, A. A.; Aleshina, G. M.; Shamova, O. V.; Korneva, H. A.; Lehrer, R. I., Protegrins Leukocyte Antimicrobial Peptides That Combine Features of Corticostatic Defensins and Tachyplesins. FEBS Letters 1993, 327, 231-236.

(94) Bulet, P.; Stocklin, R.; Menin, L., Anti-Microbial Peptides: From Invertebrates to Vertebrates. Immunol. Rev. 2004, 198, 169-184.

(95) Ganz, T.; Selsted, M. E.; Szklarek, D.; Harwig, S. S. L.; Daher, K.; Bainton, D. F.; Lehrer, R. I., Defensins - Natural Peptide Antibiotics of Human-Neutrophils. J. Clin. Invest. 1985, 76, 1427-1435.

(96) Selsted, M. E.; Ouellette, A. J., Mammalian Defensins in the Antimicrobial Immune Response. Nature Immun. 2005, 6, 551-557.

(97) Romeo, D.; Skerlavaj, B.; Bolognesi, M.; Gennaro, R., Structure and Bactericidal Activity of an Antibiotic Dodecapeptide Purified from Bovine Neutrophils. J. Biol. Chem. 1988, 263, 9573-9575. 
(98) Selsted, M. E.; Novotny, M. J.; Morris, W. L.; Tang, Y. Q.; Smith, W.; Cullor, J. S., Indolicidin, a Novel Bactericidal Tridecapeptide Amide from Neutrophils. J. Biol. Chem. 1992, 267, 4292-4295.

(99) Debono, M.; Abbott, B. J.; Molloy, R. M.; Fukuda, D. S.; Hunt, A. H.; Daupert, V. M.; Counter, F. T.; Ott, J. L.; Carrell, C. B.; Howard, L. C., et al., Enzymatic and Chemical Modifications of Lipopeptide Antibiotic A21978C - the Synthesis and Evaluation of Daptomycin (LY146032). J. Antibiot. 1988, 41, 1093-1105.

(100) Woodworth, J. R.; Nyhart, E. H.; Brier, G. L.; Wolny, J. D.; Black, H. R., Single-Dose Pharmacokinetics and Antibacterial Activity of Daptomycin, a New Lipopeptide Antibiotic, in Healthy-Volunteers. Antimicrob. Agents Chemother. 1992, 36, 318-325.

(101) Baltz, R. H.; Miao, V.; Wrigley, S. K., Natural Products to Drugs: Daptomycin and Related Lipopeptide Antibiotics. Nat. Prod. Rep. 2005, 22, 717-741.

(102) Soto, C.; Sigurdsson, E. M.; Morelli, L.; Kumar, R. A.; Castaño, E. M.; Frangione, B., Beta-Sheet Breaker Peptides Inhibit Fibrillogenesis in a Rat Brain Model of Amyloidosis: Implications for Alzheimer's Therapy. Nature Medicine 1998, 4, 822-826.

(103) Snyder, S. H., Brain Peptides as Neurotransmitters. Science 1980, 209, 976-983.

(104) Wright, J. W.; Harding, J. W., Brain Angiotensin Receptor Subtypes in the Control of Physiological and Behavioral-Responses. Neurosci. Biobehav. Rev. 1994, 18, 21-53.

(105) Fyhrquist, F.; Saijonmaa, O., Renin-Angiotensin System Revisited. J. Internal Med. 2008, 264, 224-236. 
(106) Li, P.; Chappell, M. C.; Ferrario, C. M.; Brosnihan, K. B., Angiotensin-(1-7) Augments Bradykinin-Induced Vasodilation by Competing with ACE and Releasing Nitric Oxide. Hypertension 1997, 29, 394-400.

(107) Regoli, D.; Barabe, J., Pharmacology of Bradykinin and Related Kinins. Pharmacol. Rev. 1980, 32, 1-46.

(108) Dray, A.; Perkins, M., Bradykinin and Inflammatory Pain. Trends Neurosci. 1993, 16, 99-104.

(109) Simerska, P.; Moyle, P. M.; Toth, I., Modern Lipid-, Carbohydrate-, and Peptide-Based Delivery Systems for Peptide, Vaccine, and Gene Products. Med. Res. Rev. 2011, 31, 520-547.

(110) Bøler, J.; Enzmann, F.; Folkers, K.; Bowers, C. Y.; Schally, A. V., The Identity of Critical and Hormonal Properties of the Thyrotropin Releasing Hormone and Pyroglutamyl-Histidyl-Proline Amide. Biochem. Biophys. Res. Commun. 1969, $37,705-710$.

(111) Mullur, R.; Liu, Y. Y.; Brent, G. A., Thyroid Hormone Regulation of Metabolism. Physiol. Rev. 2014, 94, 355-382.

(112) Nillni, E. A.; Sevarino, K. A., The Biology of Pro-Thyrotropin-Releasing Hormone-Derived Peptides. Endocr. Rev. 1999, 20, 599-648.

(113) Guillemin, R., Hypothalamic Hormones A.K.A. Hypothalamic Releasing Factors. J. Endocrinol. 2005, 184, 11-28.

(114) Millar, R. P.; Lu, Z. L.; Pawson, A. J.; Flanagan, C. A.; Morgan, K.; Maudsley, S. R., Gonadotropin-Releasing Hormone Receptors. Endocr. Rev. 2004, 25, $235-275$.

(115) Bauer, W.; Briner, U.; Doepfner, W.; Haller, R.; Huguenin, R.; Marbach, P.; Petcher, T. J.; Pless, J., SMS 201-995 - a Very Potent and Selective Octapeptide 
Analog of Somatostatin with Prolonged Action. Life Sciences 1982, 31, 11331140.

(116) Lamberts, S. W. J.; vanderLely, A. J.; deHerder, W. W.; Hofland, L. J., Drug Therapy - Octreotide. New Engl. J. Med. 1996, 334, 246-254.

(117) Heron, I.; Thomas, F.; Dero, M.; Gancel, A.; Ruiz, J. M.; Schatz, B.; Kuhn, J. M., Pharmacokinetics and Efficacy of a Long-Acting Formulation of the New Somatostatin Analog BIM-23014 in Patients with Acromegaly. J. Clin. Endocrinol. Metab. 1993, 76, 721-727.

(118) Hofland, L. J.; Vankoetsveld, P. M.; Waaijers, M.; Zuyderwijk, J.; Lamberts, S. W. J., Relative Potencies of the Somatostatin Analogs Octreotide, BIM-23014, and RC-160 on the Inhibition of Hormone-Release by Cultured Human Endocrine Tumor-Cells and Normal Rat Anterior-Pituitary-Cells. Endocrinology 1994, 134, 301-306.

(119) Hannon, J. P.; Nunn, C.; Stolz, B.; Bruns, C.; Weckbecker, G.; Lewis, I.; Troxler, T.; Hurth, K.; Hoyer, D., Drug Design at Peptide Receptors Somatostatin Receptor Ligands. J. Mol. Neurosci. 2002, 18, 15-27.

(120) Bradwejn, J.; Koszycki, D.; Shriqui, C., Enhanced Sensitivity to Cholecystokinin Tetrapeptide in Panic Disorder - Clinical and Behavioral Findings. Archives of General Psychiatry 1991, 48, 603-610.

(121) Balbirnie, M.; Grothe, R.; Eisenberg, D. S., An Amyloid-Forming Peptide from the Yeast Prion Sup35 Reveals a Dehydrated $\beta$-Sheet Structure for Amyloid. Proc. Nat. Acad. Sci USA 2001, 98, 2375-2380.

(122) Nelson, R.; Sawaya, M. R.; Balbirnie, M.; Madsen, A. O.; Riekel, C.; Grothe, R.; Eisenberg, D., Structure of the Cross- $\beta$ Spine of Amyloid-Like Fibrils. Nature (London) 2005, 435, 773-778. 
(123) von Bergen, M.; Friedhoff, P.; Biernat, J.; Heberle, J.; Mandelkow, E. M.;

Mandelkow, E., Assembly of $\tau$ Protein into Alzheimer Paired Helical Filaments Depends on a Local Sequence Motif $\left({ }^{306} V_{Q}\right.$ IVYK $\left.^{311}\right)$ Forming $\beta$ Structure. Proc. Nat. Acad. Sci USA 2000, 97, 5129-5134.

(124) Goux, W. J.; Kopplin, L.; Nguyen, A. D.; Leak, K.; Rutkofsky, M.; Shanmuganandam, V. D.; Sharma, D.; Inouye, H.; Kirschner, D. A., The Formation of Straight and Twisted Filaments from Short Tau Peptides. J. Biol. Chem. 2004, 279, 26868-26875.

(125) Sawaya, M. R.; Sambashivan, S.; Nelson, R.; Ivanova, M. I.; Sievers, S. A.; Apostol, M. I.; Thompson, M. J.; Balbirnie, M.; Wiltzius, J. J. W.; McFarlane, H. T., et al., Atomic Structures of Amyloid Cross- $\beta$ Spines Reveal Varied Steric Zippers. Nature 2007, 447, 453-457.

(126) Zhang, S. G.; Holmes, T.; Lockshin, C.; Rich, A., Spontaneous Assembly of a Self-Complementary Oligopeptide to Form a Stable Macroscopic Membrane. Proc. Nat. Acad. Sci USA 1993, 90, 3334-3338.

(127) Zhang, S. G.; Holmes, T. C.; Dipersio, C. M.; Hynes, R. O.; Su, X.; Rich, A., Self-Complementary Oligopeptide Matrices Support Mammalian-Cell Attachment. Biomaterials 1995, 16, 1385-1393.

(128) Zhang, S., Emerging Biological Materials through Molecular Self-Assembly. Biotechnology Advances 2002, 20, 321-339.

(129) Zhao, X.; Zhang, S., Fabrication of Molecular Materials Using Peptide Construction Motifs. Trends Biotech. 2004, 22, 470-476.

(130) Reches, M.; Gazit, E., Casting Metal Nanowires within Discrete SelfAssembled Peptide Nanotubes. Science 2003, 300, 625-627. 
(131) Turk, B. E.; Huang, L. L.; Piro, E. T.; Cantley, L. C., Determination of Protease Cleavage Site Motifs Using Mixture-Based Oriented Peptide Libraries. Nature Biotech. 2001, 19, 661-667.

(132) Patterson, J.; Hubbell, J. A., Enhanced Proteolytic Degradation of Molecularly Engineered PEG Hydrogels in Response to MMP-1 and MMP-2. Biomaterials 2010, 31, 7836-7845.

(133) Hughes, J.; Smith, T. W.; Kosterlitz, H. W.; Fothergill, L. A.; Morgan, B. A.; Morris, H. R., Identification of Two Related Pentapeptides from Brain with Potent Opiate Agonist Activity. Nature 1975, 258, 577-579.

(134) Zadina, J. E.; Hackler, L.; Ge, L. J.; Kastin, A. J., A Potent and Selective Endogenous Agonist for the $\mu$-Opiate Receptor. Nature 1997, 386, 499-502.

(135) Wilson, A. M.; Soignier, R. D.; Zadina, J. E.; Kastin, A. J.; Nores, W. L.;

Olson, R. D.; Olson, G. A., Dissociation of Analgesic and Rewarding Effects of Endomorphin-1 in Rats. Peptides 2000, 21, 1871-1874.

(136) Maggio, J. E., Tachykinins. Ann. Rev. Neurosci. 1988, 11, 13-28.

(137) Kreuter, J., Nanoparticulate Systems for Brain Delivery of Drugs. Adv. Drug Del. Rev. 2001, 47, 65-81.

(138) Meister, A.; Anderson, M. E., Glutathione. Annu. Rev. Biochem. 1983, 52, 711760.

(139) Boldryev, A. A.; Dupin, A. M.; Bunin, A. Y.; Babizhaev, M. A.; Severin, S. E., The Antioxidative Properties of Carnosine, a Natural Histidine Containing Dipeptide. Biochem. Internat. 1987, 15, 1105-1113.

(140) Quinn, P. J.; Boldyrev, A. A.; Formazuyk, V. E., Carnosine - Its Properties, Functions and Potential Therapeutic Applications. Mol. Asp. Med. 1992, 13, 379-444. 
(141) Borel, J. F., Pharmacology of Cyclosporine (Sandimmune).4. Pharmacological Properties Invivo. Pharmacol. Rev. 1989, 41, 259-370.

(142) Shevach, E. M., The Effects of Cyclosporin-A on the Immune System. Annu. Rev. Immunol. 1985, 3, 397-423.

(143) Faulds, D.; Goa, K. L.; Benfield, P., Cyclosporine - a Review of Its Pharmacodynamic and Pharmacokinetic Properties, and Therapeutic Use in Immunoregulatory Disorders. Drugs 1993, 45, 953-1040.

(144) Sassenfeld, H. M.; Brewer, S. J., A Polypeptide Fusion Designed for the Purification of Recombinant Proteins. Bio-Technology 1984, 2, 76-81.

(145) Hochuli, E.; Dobeli, H.; Schacher, A., New Metal Chelate Adsorbent Selective for Proteins and Peptides Containing Neighboring Histidine-Residues. Journal of Chromatography 1987, 411, 177-184.

(146) Hochuli, E.; Bannwarth, W.; Dobeli, H.; Gentz, R.; Stuber, D., Genetic Approach to Facilitate Purification of Recombinant Proteins with a Novel Metal Chelate Adsorbent. Bio-Technology 1988, 6, 1321-1325.

(147) Schmidt, T. G. M.; Skerra, A., The Random Peptide Library-Assisted Engineering of a C-Terminal Affinity Peptide, Useful for the Detection and Purification of a Functional Ig Fv Fragment. Protein Eng. 1993, 6, 109-122.

(148) Schmidt, T. G. M.; Koepke, J.; Frank, R.; Skerra, A., Molecular Interaction between the Strep-Tag Affinity Peptide and Its Cognate Target, Streptavidin. $J$. Molec. Biol. 1996, 255, 753-766.

(149) Kipriyanov, S. M.; Kupriyanova, O. A.; Little, M.; Moldenhauer, G., Rapid Detection of Recombinant Antibody Fragments Directed against Cell-Surface Antigens by Flow Cytometry. J. Immunol. Meth. 1996, 196, 51-62. 
(150) Hopp, T. P.; Prickett, K. S.; Price, V. L.; Libby, R. T.; March, C. J.; Cerretti, D. P.; Urdal, D. L.; Conlon, P. J., A Short Polypeptide Marker Sequence Useful for Recombinant Protein Identification and Purification. Bio-Technology 1988, 6, $1204-1210$

(151) Umezawa, H., Natural and Artificial Bleomycins Chemistry and Anti Tumor Activities. Pure Appl. Chem. 1971, 28, 665-680.

(152) Umezawa, H.; Maeda, K.; Takeuchi, T.; Okami, Y., New Antibiotics, Bleomycin a and B. J. Antibiotics, Series A 1966, 19, 200.

(153) Umezawa, H., Recent Studies on Bleomycin. Lloydia- J. Natural Products 1977, 40, 67-81.

(154) Burger, R. M., Cleavage of Nucleic Acids by Bleomycin. Chem. Rev. 1998, 98, 1153-1169.

(155) Schwarzer, D.; Finking, R.; Marahiel, M. A., Nonribosomal Peptides: From Genes to Products. Nat. Prod. Rep. 2003, 20, 275-287.

(156) Pettit, G. R.; Kamano, Y.; Herald, C. L.; Tuinman, A. A.; Boettner, F. E.; Kizu, H.; Schmidt, J. M.; Baczynskyj, L.; Tomer, K. B.; Bontems, R. J., Antineoplastic Agents.136. The Isolation and Structure of a Remarkable Marine Animal Antineoplastic Constituent - Dolastatin 10. J. Am. Chem. Soc. 1987, $109,6883-6885$.

(157) Bai, R.; Roach, M. C.; Jayaram, S. K.; Barkoczy, J.; Pettit, G. R.; Luduena, R. F.; Hamel, E., Differential-Effects of Active Isomers, Segments, and Analogs of Dolastatin-10 on Ligand Interactions with Tubulin - Correlation with Cytotoxicity. Biochem. Pharmacol. 1993, 45, 1503-1515.

(158) Han, J. W.; Ahn, S. H.; Park, S. H.; Wang, S. Y.; Bae, G. U.; Seo, D. W.; Kwon, H. K.; Hong, S.; Lee, H. Y.; Lee, Y. W., et al., Apicidin, a Histone 
Deacetylase Inhibitor, Inhibits Proliferation of Tumor Cells Via Induction of p21 $1^{\mathrm{WAF} 1 / \mathrm{Cip} 1}$ and Gelsolin. Cancer Res. 2000, 60, 6068-6074.

(159) Kwon, S. H.; Ahn, S. H.; Kim, Y. K.; Bae, G. U.; Yoon, J. W.; Hong, S.; Lee, H. Y.; Lee, Y. W.; Lee, H. W.; Han, J. W., Apicidin, a Histone Deacetylase Inhibitor, Induces Apoptosis and Fas/Fas Ligand Expression in Human Acute Promyelocytic Leukemia Cells. J. Biol. Chem. 2002, 277, 2073-2080.

(160) Khan, N.; Jeffers, M.; Kumar, S.; Hackett, C.; Boldog, F.; Khramtsov, N.; Qian, X. Z.; Mills, E.; Berghs, S. C.; Carey, N., et al., Determination of the Class and Isoform Selectivity of Small-Molecule Histone Deacetylase Inhibitors.

Biochem. J. 2008, 409, 581-589.

(161) Ueda, H.; Nakajima, H.; Hori, Y.; Fujita, T.; Nishimura, M.; Goto, T.; Okuhara, M., FR901228, a Novel Antitumor Bicyclic Depsipeptide Produced by Chromobacterium Violaceum No. 968.1. Taxonomy, Fermentation, Isolation, Physicochemical and Biological Properties, and Antitumor-Activity. J. Antibiot. 1994, 47, 301-310.

(162) Sandor, V.; Bakke, S.; Robey, R. W.; Kang, M. H.; Blagosklonny, M. V.; Bender, J.; Brooks, R.; Piekarz, R. L.; Tucker, E.; Figg, W. D., et al., Phase I Trial of the Histone Deacetylase Inhibitor, Depsipeptide (FR901228, NSC 630176), in Patients with Refractory Neoplasms. Clin. Cancer Res. 2002, 8, 718-728.

(163) Coiffier, B.; Pro, B.; Prince, H. M.; Foss, F.; Sokol, L.; Greenwood, M.; Caballero, D.; Borchmann, P.; Morschhauser, F.; Wilhelm, M., et al., Results from a Pivotal, Open-Label, Phase II Study of Romidepsin in Relapsed or Refractory Peripheral T-Cell Lymphoma after Prior Systemic Therapy. J. Clin. Oncol. 2012, 30, 631-636. 
(164) Piekarz, R. L.; Frye, R.; Prince, H. M.; Kirschbaum, M. H.; Zain, J.; Allen, S. L.; Jaffe, E. S.; Ling, A.; Turner, M.; Peer, C. J., et al., Phase 2 Trial of Romidepsin in Patients with Peripheral T-Cell Lymphoma. Blood 2011, 117, $5827-5834$

(165) West, A. C.; Johnstone, R. W., New and Emerging HDAC Inhibitors for Cancer Treatment. J. Clin. Invest. 2014, 124, 30-39.

(166) Whittaker, S. J.; Demierre, M. F.; Kim, E. J.; Rook, A. H.; Lerner, A.; Duvic, M.; Scarisbrick, J.; Reddy, S.; Robak, T.; Becker, J. C., et al., Final Results from a Multicenter, International, Pivotal Study of Romidepsin in Refractory Cutaneous T-Cell Lymphoma. J. Clin. Oncol. 2010, 28, 4485-4491.

(167) Seiser, T.; Kamena, F.; Cramer, N., Synthesis and Biological Activity of Largazole and Derivatives. Angew. Chem. Int. Ed. Engl. 2008, 47, 6483-6485.

(168) Taori, K.; Paul, V. J.; Luesch, H., Structure and Activity of Largazole, a Potent Antiproliferative Agent from the Floridian Marine Cyanobacterium Symploca Sp. J. Am. Chem. Soc. 2008, 130, 1806-1807.

(169) Mazur, R. H.; Schlatter, J. M.; Goldkamp, A. H., Structure-Taste Relationships of Some Dipeptides. J. Am. Chem. Soc. 1969, 91, 2684-91.

(170) Magnuson, B. A.; Burdock, G. A.; Doull, J.; Kroes, R. M.; Marsh, G. M.; Pariza, M. W.; Spencer, P. S.; Waddell, W. J.; Walker, R.; Williams, G. M., Aspartame: A Safety Evaluation Based on Current Use Levels, Regulations, and Toxicological and Epidemiological Studies. Crit. Rev. Toxicol. 2007, 37, 629727.

(171) Yamada, K. M., Adhesive Recognition Sequences. J. Biol. Chem. 1991, 266, 12809-12812. 
(172) Hern, D. L.; Hubbell, J. A., Incorporation of Adhesion Peptides into

Nonadhesive Hydrogels Useful for Tissue Resurfacing. J. Biomed. Mater. Res. 1998, 39, 266-276.

(173) Hartgerink, J. D.; Beniash, E.; Stupp, S. I., Self-Assembly and Mineralization of Peptide-Amphiphile Nanofibers. Science 2001, 294, 1684-1688.

(174) Hartgerink, J. D.; Beniash, E.; Stupp, S. I., Peptide-Amphiphile Nanofibers: A Versatile Scaffold for the Preparation of Self-Assembling Materials. Proc. Nat. Acad. Sci USA 2002, 99, 5133-5138.

(175) Guler, M. O.; Hsu, L.; Soukasene, S.; Harrington, D. A.; Hulvat, J. F.; Stupp, S. I., Presentation of RGDS Epitopes on Self-Assembled Nanofibers of Branched Peptide Amphiphiles. Biomacromol. 2006, 7, 1855-1863.

(176) Storrie, H.; Guler, M. O.; Abu-Amara, S. N.; Volberg, T.; Rao, M.; Geiger, B.; Stupp, S. I., Supramolecular Crafting of Cell Adhesion. Biomaterials 2007, 28, $4608-4618$.

(177) Cheng, G.; Castelletto, V.; Jones, R.; Connon, C. J.; Hamley, I. W., Hydrogelation of Self-Assembling RGD-Based Peptides. Soft Matter 2011, 7 , $1326-1333$.

(178) Castelletto, V.; Moulton, C. M.; Cheng, G.; Hamley , I. W.; Hicks, M. R.; Rodger, A.; López-Pérez, D. E.; Revilla-López, G.; Alemán, C., Self-Assembly of Fmoc-Tetrapeptides Based on the RGDS Cell Adhesion Motif. Soft Matter 2011, 7, 11405-11415.

(179) Mager, M. D.; LaPointe, V.; Stevens, M. M., Exploring and Exploiting Chemistry at the Cell Surface. Nature Chem. 2011, 3, 582-589.

(180) Samanen, J.; Ali, F.; Romoff, T.; Calvo, R.; Sorenson, E.; Vasko, J.; Storer, B.; Berry, D.; Bennett, D.; Strohsacker, M., et al., Development of a Small RGD 
Peptide Fibrinogen Receptor Antagonist with Potent Antiaggregatory Activity Invitro. J. Med. Chem. 1991, 34, 3114-3125.

(181) Alig, L.; Edenhofer, A.; Hadvary, P.; Hurzeler, M.; Knopp, D.; Muller, M.; Steiner, B.; Trzeciak, A.; Weller, T., Low-Molecular-Weight, Nonpeptide Fibrinogen Receptor Antagonists. J. Med. Chem. 1992, 35, 4393-4407.

(182) Muraoka, T.; Koh, C.-Y.; Cui, H.; Stupp, S. I., Light-Triggered Bioactivity in Three Dimensions. Angew. Chem., Int. Ed. Engl. 2009, 48, 5946-5949.

(183) Webber, M. J.; Tongers, J.; Renault, M.-A.; Roncalli, J. G.; Losordo, D. W.; Stupp, S. I., Development of Bioactive Peptide Amphiphiles for Therapeutic Cell Delivery. Acta Biomaterialia 2010, 6, 3-11.

(184) Jin, Y.; Xu, X.-D.; Chen, C.-S.; Cheng, S.-X.; Zhang, X.-Z.; Zhuo, R.-X., Bioactive Amphiphilic Peptide Derivatives with pH Triggered Morphology and Structure. Macromol. Rapid Commun. 2009, 29, 1726-1731.

(185) Cheng, G.; Castelletto, V.; Moulton, C. M.; Newby, G. E.; Hamley , I. W., Hydrogelation and Self-Assembly of Fmoc-Tripeptides: Unexpected Influence of Sequence on Self-Assembled Fibril Structure, and Hydrogel Modulus and Anisotropy. Langmuir 2010, 26, 4990-4998.

(186) Castelletto, V.; Gouveia, R. J.; Connon, C. J.; Hamley , I. W., New RgdPeptide Amphiphile Mixtures Containing a Negatively Charged Diluent. Faraday Discuss. 2013, 166, 381-397.

(187) Gouveia, R. M.; Jones, R. R.; Hamley, I. W.; Connon, C. J., The Bioactivity of Composite Fmoc-Rgds-Collagen Gels. Biomater. Sci. 2014, 2, 1222-1229.

(188) Pierschbacher, M. D.; Ruoslahti, E., Cell Attachment Activity of Fibronectin can be Duplicated by Small Synthetic Fragments of the Molecule. Nature 1984, 309, 30-33. 
(189) Pierschbacher, M. D.; Ruoslahti, E., Influence of Stereochemistry of the Sequence Arg-Gly-Asp-Xaa on Binding Specificity in Cell Adhesion. J. Biol. Chem. 1987, 262, 17294-17298.

(190) Hirano, Y.; Okuno, M.; Hayashi, T.; Goto, K.; Nakajima, A., Cell-Attachment Activities of Surface Immobilized Oligopeptides RGD, RGDS, RGDV, RGDT, and YIGSR toward Five Cell Lines. J. Biomater. Sci.-Polym. Ed. 1993, 4, 235 243.

(191) Hersel, U.; Dahmen, C.; Kessler, H., RGD Modified Polymers: Biomaterials for Stimulated Cell Adhesion and Beyond. Biomaterials 2003, 24, 4385-4415.

(192) Scarborough, R. M.; Rose, J. W.; Hsu, M. A.; Phillips, D. R.; Fried, V. A.; Campbell, A. M.; Nannizzi, L.; Charo, I. F., Barbourin - a GPIIb-IIIa-Specific Integrin Antagonist from the Venom of Sistrurus M. Barbouri. J. Biol. Chem. 1991, 266, 9359-9362.

(193) Oshikawa, K.; Terada, S., Ussuristatin 2, a Novel KGD-Bearing Disintegrin from Agkistrodon Ussuriensis Venom. J. Biochem. 1999, 125, 31-35.

(194) Liyanage, W.; Vats, K.; Rajbhandary, A.; Benoit, D. S. W.; Nilsson, B. L., Multicomponent Dipeptide Hydrogels as Extracellular Matrix-Mimetic Scaffolds for Cell Culture Applications. Chem. Comm. 2015, 51, 11260-11263.

(195) Keung, A. J.; Kumar, S.; Schaffer, D. V., Presentation Counts:

Microenvironmental Regulation of Stem Cells by Biophysical and Material Cues. In Ann. Rev. Cell Develop. Biol., Vol 26, Schekman, R.; Goldstein, L.; Lehmann, R., Eds. Annual Reviews: Palo Alto, 2010; Vol. 26, pp 533-556. (196) Aumailley, M.; Gurrath, M.; Muller, G.; Calvete, J.; Timpl, R.; Kessler, H., Arg-Gly-Asp Constrained within Cyclic Pentapeptides - Strong and Selective 
Inhibitors of Cell-Adhesion to Vitronectin and Laminin Fragment-P1. Febs Letters 1991, 291, 50-54.

(197) Heckmann, D.; Kessler, H., Design and Chemical Synthesis of Integrin Ligands. Methods in Enzymology 2007, 426, 463-503.

(198) Heckmann, D.; Meyer, A.; Marinelli, L.; Zahn, G.; Stragies, R.; Kessler, H., Probing Integrin Selectivity: Rational Design of Highly Active and Selective Ligands for the $\alpha 5 \beta_{1}$ and $\alpha_{v} \beta_{3}$ Integrin Receptor. Angew. Chem. Int. Ed. Engl. 2007, 46, 3571-3574.

(199) Dechantsreiter, M. A.; Planker, E.; Matha, B.; Lohof, E.; Holzemann, G.; Jonczyk, A.; Goodman, S. L.; Kessler, H., N-Methylated Cyclic RGD Peptides as Highly Active and Selective $\alpha_{v} \beta_{3}$ Integrin Antagonists. J. Med. Chem. 1999, 42, 3033-3040.

(200) Aucoin, L.; Griffith, C. M.; Pleizier, G.; Deslandes, Y.; Sheardown, H., Interactions of Corneal Epithelial Cells and Surfaces Modified with Cell Adhesion Peptide Combinations. J. Biomater. Sci.-Polym. Ed. 2002, 13, 447462.

(201) Kokkoli, E.; Mardilovich, A.; Wedekind, A.; Rexeisen, E. L.; Garg, A.; Craig, J. A., Self-Assembly and Applications of Biomimetic and Bioactive Peptideamphiphiles. Soft Matter 2008, 2, 1015-1024.

(202) Mardilovich, A.; Craig, J. A.; McCammon, M. Q.; Garg, A.; Kokkoli, E., Design of a Novel Fibronectin-Mimetic Peptide-Amphiphile for Functionalized Biomaterials. Langmuir 2006, 22, 3259-3264.

(203) Shroff, K.; Pearce, T. R.; Kokkoli, E., Enhanced Integrin Mediated Signaling and Cell Cycle Progression on Fibronectin Mimetic Peptide Amphiphile Monolayers. Langmuir 2012, 28, 1858-1865. 
(204) Mardilovich, A.; Kokkoli, E., Biomimetic Peptide-Amphiphiles for Functional Biomaterials: The Role of GRGDSP and PHSRN. Biomacromolecules 2004, 5, 950-957.

(205) Hubbell, J. A.; Massia, S. P.; Desai, N. P.; Drumheller, P. D., Endothelial CellSelective Materials for Tissue Engineering in the Vascular Graft Via a New Receptor. Bio-Technology 1991, 9, 568-572.

(206) Massia, S. P.; Hubbell, J. A., Vascular Endothelial-Cell Adhesion and Spreading Promoted by the Peptide REDV of the IIICS Region of Plasma Fibronectin Is Mediated by Integrin $\alpha_{4} \beta_{1}$. J. Biol. Chem. 1992, 267, 1401914026.

(207) Mann, B. K.; West, J. L., Cell Adhesion Peptides Alter Smooth Muscle Cell Adhesion, Proliferation, Migration, and Matrix Protein Synthesis on Modified Surfaces and in Polymer Scaffolds. J. Biomed. Mater. Res. 2002, 60, 86-93. (208) Mann, B. K.; Tsai, A. T.; Scott-Burden, T.; West, J. L., Modification of Surfaces with Cell Adhesion Peptides Alters Extracellular Matrix Deposition. Biomaterials 1999, 20, 2281-2286.

(209) Saiki, I.; Murata, J.; Iida, J.; Sakurai, T.; Nishi, N.; Matsuno, K.; Azuma, I., Antimetastatic Effects of Synthetic Polypeptides Containing Repeated Structures of the Cell Adhesive Arg-Gly-Asp (RGD) and Tyr-Ile-Gly-Ser-Arg (YIGSR) Sequences. Br. J. Cancer 1989, 60, 722-728.

(210) Iwamoto, Y.; Nomizu, M.; Yamada, Y.; Ito, Y.; Tanaka, K.; Sugioka, Y., Inhibition of Angiogenesis, Tumour Growth and Experimental Metastasis of Human Fibrosarcoma Cells Ht1080 by a Multimeric Form of the Laminin Sequence Tyr-Ile-Gly-Ser-Arg (YIGSR). Br. J. Cancer 1996, 73, 589-595. 
(211) Silva, G. A.; Czeisler, C.; Niece, K. L.; Beniash, E.; Harrington, D. A.; Kessler, J. A.; Stupp, S. I., Selective Differentiation of Neural Progenitor Cells by HighEpitope Density Nanofibers. Science 2004, 303, 1352-1355.

(212) Tysseling-Mattiace, V. M.; Sahni, V.; Niece, K. L.; Birch, D.; Czeisler, C.;

Fehlings, M. G.; Stupp, S. I.; Kessler, J. A., Self-Assembling Nanofibers Inhibit Glial Scar Formation and Promote Axon Elongation after Spinal Cord Injury. $J$. Neurosci. 2008, 28, 3814-3823.

(213) Sur, S.; Pashuck, E. T.; Guler, M. O.; Ito, M.; Stupp, S. I.; Launey, T., A Hybrid Nanofiber Matrix to Control the Survival and Maturation of Brain Neurons. Biomaterials 2012, 33, 545-555.

(214) Weber, L. M.; Hayda, K. N.; Haskins, K.; Anseth, K. S., The Effects of CellMatrix Interactions on Encapsulated $\beta$-Cell Function within Hydrogels Functionalized with Matrix-Derived Adhesive Peptides. Biomaterials 2007, 28, 3004-3011.

(215) Anderson, J. M.; Kushwaha, M.; Tambralli, A.; Bellis, S. L.; Camata, R. P.; Jun, H. W., Osteogenic Differentiation of Human Mesenchymal Stem Cells Directed by Extracellular Matrix-Mimicking Ligands in a Biomimetic SelfAssembled Peptide Amphiphile Nanomatrix. Biomacromol. 2009, 10, 29352944.

(216) Garcia, A. J.; Reyes, C. D., Bio-Adhesive Surfaces to Promote Osteoblast Differentiation and Bone Formation. J. Dent. Res. 2005, 84, 407-413.

(217) Wojtowicz, A. M.; Shekaran, A.; Oest, M. E.; Dupont, K. M.; Templeman, K. L.; Hutmacher, D. W.; Guldberg, R. E.; Garcia, A. J., Coating of Biomaterial Scaffolds with the Collagen-Mimetic Peptide Gfoger for Bone Defect Repair. Biomaterials 2010, 31, 2574-2582. 
(218) Rathore, O.; Sogah, D. Y., Nanostructure Formation through B-Sheet SelfAssembly in Silk-Based Materials. Macromolecules 2001, 34, 1477-1486.

(219) Vepari, C.; Kaplan, D. L., Silk as a Biomaterial. Prog. Polym. Sci. 2007, 32, 991-1007.

(220) Termonia, Y., Molecular Modeling of Spider Silk Elasticity. Macromolecules 1994, 27, 7378-7381.

(221) Urry, D. W., Physical Chemistry of Biological Free Energy Transduction as Demonstrated by Elastic Protein-Based Polymers. J. Phys. Chem. B 1997, 101, 11007-11028.

(222) Urry, D. W., Entropic Elastic Processes in Protein Mechanisms.1. Elastic Structure Due to an Inverse Temperature Transition and Elasticity Due to Internal Chain Dynamics. J. Protein Chem. 1988, 7, 1-34.

(223) MacEwan, S. R.; Chilkoti, A., Elastin-Like Polypeptides: Biomedical Applications of Tunable Biopolymers. Biopolymers 2010, 94, 60-77.

(224) Anderson, S. O., Characterization of a New Type of Cross-Linkage in Resilin, a Rubber-Like Protein. Biochem. Biophys. Acta 1963, 69, 249-262.

(225) Parton, R. G.; Richards, A. A., Lipid Rafts and Caveolae as Portals for Endocytosis: New Insights and Common Mechanisms. Traffic 2003, 4, 724738.

(226) Gupta, B.; Levchenko, T. S.; Torchilin, V. P., Intracellular Delivery of Large Molecules and Small Particles by Cell-Penetrating Proteins and Peptides. $A d v$. Drug Del. Rev. 2005, 57, 637-651.

(227) Koren, E.; Torchilin, V. P., Cell-Penetrating Peptides: Breaking through to the Other Side. Trends Mol. Med 2012, 18, 385-393. 
(228) Kauffman, W. B.; Fuselier, T.; He, J.; Wimley, W. C., Mechanism Maters: A Taxonomy of Cell Penetrating Peptices. Trends Biochem. Sci. 2015, 40, 749764.

(229) Zhang, D. D.; Wang, J. X.; Xu, D. G., Cell-Penetrating Peptides as Noninvasive Transmembrane Vectors for the Development of Novel Multifunctional DrugDelivery Systems. J. Controlled Release 2016, 229, 130-139.

(230) Futaki, S., Membrane-Permeable Arginine-Rich Peptides and the Translocation Mechanisms. Adv. Drug Del. Rev. 2005, 57, 547-558.

(231) Chugh, A.; Eudes, F., Translocation and Nuclear Accumulation of Monomer and Dimer of Hiv-1 Tat Basic Domain in Triticale Mesophyll Protoplasts. Biochim. Biophys. Acta-Biomembr. 2007, 1768, 419-426.

(232) Lakshmanan, M.; Kodama, Y.; Yoshizumi, T.; Sudesh, K.; Numata, K., Rapid and Efficient Gene Delivery into Plant Cells Using Designed Peptide Carriers. Biomacromol. 2013, 14, 10-16.

(233) Monreal, I. A.; Liu, Q.; Tyson, K.; Bland, T.; Dalisay, D. S.; Adams, E. V.; Wayman, G. A.; Aguilar, H. C.; Saludes, J. P., Branched Dimerization of Tat Peptide Improves Permeability to HeLa and Hippocampal Neuronal Cells. Chem. Comm. 2015, 51, 5463-5466.

(234) Mishra, A.; Lai, G. H.; Schmidt, N. W.; Sun, V. Z.; Rodriguez, A. R.; Tong, R.; Tang, L.; Cheng, J. J.; Deming, T. J.; Kamei, D. T., et al., Translocation of HIV Tat Peptide and Analogues Induced by Multiplexed Membrane and Cytoskeletal Interactions. Proc. Nat. Acad. Sci USA 2011, 108, 16883-16888.

(235) Schmidt, N.; Mishra, A.; Lai, G. H.; Wong, G. C. L., Arginine-Rich CellPenetrating Peptides. FEBS Letters 2009, 584, 1806-1813. 
(236) Nakase, I.; Niwa, M.; Takeuchi, T.; Sonomura, K.; Kawabata, N.; Koike, Y.; Takehashi, M.; Tanaka, S.; Ueda, K.; Simpson, J. C., et al., Cellular Uptake of Arginine-Rich Peptides: Roles for Macropinocytosis and Actin Rearrangement. Molec. Therapy 2004, 10, 1011-1022.

(237) Mandal, D.; Shirazi, A. N.; Parang, K., Cell-Penetrating Homochiral Cyclic Peptides as Nuclear-Targeting Molecular Transporters. Angew. Chem. Int. Ed. Engl. 2011, 50, 9633-9637.

(238) Lättig-Tünnemann, G.; Prinz, M.; Hoffmann, D.; Behlke, J.; Palm-Apergi, C.; Morano, I.; Herce, H. D.; Cardoso, M. C., Backbone Rigidity and Static Presentation of Guanidinium Groups Increases Cellular Uptake of ArginineRich Cell-Penetrating Peptides. Nat. Commun. 2011, 2 453. DOI: 10.1038/ncomms 1459 .

(239) Qian, Z. Q.; Liu, T.; Liu, Y. Y.; Briesewitz, R.; Barrios, A. M.; Jhiang, S. M.; Pei, D. H., Efficient Delivery of Cyclic Peptides into Mammalian Cells with Short Sequence Motifs. ACS Chem. Biol. 2013, 8, 423-431.

(240) Qian, Z. Q.; Martyna, A.; Hard, R. L.; Wang, J.; Appiah-Kubi, G.; Coss, C.; Phelps, M. A.; Rossman, J. S.; Pei, D. H., Discovery and Mechanism of Highly Efficient Cyclic Cell-Penetrating Peptides. Biochemistry 2016, 55, 2601-2612. (241) Koivunen, E.; Wang, B. C.; Ruoslahti, E., Phage Libraries Displaying CyclicPeptides with Different Ring Sizes - Ligand Specificities of the RGD-Directed Integrins. Bio-Technology 1995, 13, 265-270.

(242) Pasqualini, R.; Koivunen, E.; Ruoslahti, E., $\alpha_{V}$ Integrins as Receptors for Tumor Targeting by Circulating Ligands. Nature Biotech. 1997, 15, 542-546. (243) Arap, W.; Pasqualini, R.; Ruoslahti, E., Cancer Treatment by Targeted Drug Delivery to Tumor Vasculature in a Mouse Model. Science 1998, 279, 377-380. 
(244) Koivunen, E.; Wang, B. C.; Ruoslahti, E., Isolation of a Highly Specific Ligand for the $\alpha_{5} \beta_{1}$ Integrin from a Phage Display Library. J. Cell Biol. 1994, 124, 373380.

(245) Hoffman, J. A.; Giraudo, E.; Singh, M.; Zhang, L. L.; Inoue, M.; Porkka, K.; Hanahan, D.; Ruoslahti, E., Progressive Vascular Changes in a Transgenic Mouse Model of Squamous Cell Carcinoma. Cancer Cell 2003, 4, 383-391.

(246) Agemy, L.; Friedmann-Morvinski, D.; Kotamraju, V. R.; Roth, L.; Sugahara, K. N.; Girard, O. M.; Mattrey, R. F.; Verma, I. M.; Ruoslahti, E., Targeted Nanoparticle Enhanced Proapoptotic Peptide as Potential Therapy for Glioblastoma. Proc. Nat. Acad. Sci USA 2011, 108, 17450-17455.

(247) Sugahara, K. N.; Teesalu, T.; Karmali, P. P.; Kotamraju, V. R.; Agemy, L.; Girard, O. M.; Hanahan, D.; Mattrey, R. F.; Ruoslahti, E., Tissue-Penetrating Delivery of Compounds and Nanoparticles into Tumors. Cancer Cell 2009, 16, $510-520$.

(248) Sugahara, K. N.; Teesalu, T.; Karmali, P. P.; Kotamraju, V. R.; Agemy, L.; Greenwald, D. R.; Ruoslahti, E., Coadministration of a Tumor-Penetrating Peptide Enhances the Efficacy of Cancer Drugs. Science 2010, 328, 1031-1035. (249) Simberg, D.; Duza, T.; Park, J. H.; Essler, M.; Pilch, J.; Zhang, L. L.; Derfus, A. M.; Yang, M.; Hoffman, R. M.; Bhatia, S., et al., Biomimetic Amplification of Nanoparticle Homing to Tumors. Proc. Nat. Acad. Sci USA 2007, 104, 932-936. (250) Kirkham, S.; Castelletto, V.; Hamley, I. W.; Inoue, K.; Rambo, R.; Reza, M.; Ruokolainen, J., Self-Assembly of the Cyclic Lipopeptide Daptomycin: Spherical Micelle Formation Does Not Depend on the Presence of Calcium Chloride. Chemphyschem 2016, 17, 2118-2122. 
(251) Albada, B.; Metlzer-Nolte, N., Highly Potent Antibacterial Organometallic Peptide Conjugates. Acc. Chem. Res. 2017, 50, 2510-2518.

(252) Shai, Y., Mechanism of the Binding, Insertion and Destabilization of Phospholipid Bilayer Membranes by $\alpha$-Helical Antimicrobial and Cell NonSelective Membrane-Lytic Peptides. Biochim. Biophys. Acta-Biomembr. 1999, $1462,55-70$.

(253) Schmidt, N. W.; Mishra, A.; Lai, G. H.; Davis, M.; Sanders, L. K.; Tran, D.; Garcia, A.; Tai, K. P.; McCray, P. B.; Ouellette, A. J., et al., Criterion for Amino Acid Composition of Defensins and Antimicrobial Peptides Based on Geometry of Membrane Destabilization. J. Am. Chem. Soc. 2011, 133, 67206727.

(254) Stromstedt, A. A.; Pasupuleti, M.; Schmidtchen, A.; Malmsten, M., Oligotryptophan-Tagged Antimicrobial Peptides and the Role of the Cationic Sequence. Biochim. Biophys. Acta-Biomembr. 2009, 1788, 1916-1923.

(255) Rezansoff, A. J.; Hunter, H. N.; Jing, W.; Park, I. Y.; Kim, S. C.; Vogel, H. J., Interactions of the Antimicrobial Peptide Ac-FRWWHR-NH2 with Model Membrane Systems and Bacterial Cells. J. Pept. Res. 2005, 65, 491-501.

(256) Bonmatin, J. M.; Laprevote, O.; Peypoux, F., Diversity among Microbial Cyclic Lipopeptides: Iturins and Surfactins. Activity-Structure Relationships to Design New Bioactive Agents. Comb. Chem. High Throughput Screen. 2003, 6, 541556.

(257) Jacques, P., Surfactin and Other Lipopeptides from Bacillus Spp. In Biosurfactants: From Genes to Applications, Soberón-Chávez, G., Ed. Springer, 233 Spring Street, New York, Ny 10013, United States: 2011; Vol. 20, pp 5791. 
(258) Banat, I. M.; Franzetti, A.; Gandolfi, I.; Bestetti, G.; Martinotti, M. G.; Fracchia, L.; Smyth, T. J.; Marchant, R., Microbial Biosurfactants Production, Applications and Future Potential. Appl. Microbiol. Biotech. 2010, 87, 427-444. (259) Singh, P.; Cameotra, S. S., Potential Applications of Microbial Surfactants in Biomedical Sciences. Trends Biotech. 2004, 22, 142-146.

(260) Hamley, I. W., Lipopeptides: From Self-Assembly to Bioactivity. Chem. Comm. 2015, 51, 8574-8583.

(261) Hamley, I. W.; Dehsorkhi, A.; Jauregi, P.; Seitsonen, J.; Ruokolainen, J.; Coutte, F.; Chataigné, G.; Jacques, P., Self-Assembly of Three BacteriallyDerived Bioactive Lipopeptides. Soft Matter 2013, 9, 9572-9578.

(262) Yakimov, M. M.; Timmis, K. N.; Wray, V.; Fredrickson, H. L., Characterization of a New Lipopeptide Surfactant Produced by Thermotolerant and Halotolerant Subsurface Bacillus licheniformis BAS50. Appl. Environ. Microbiol. 1995, 61, 1706-1713.

(263) Grangemard, I.; Wallach, J.; Maget-Dana, R.; Peypoux, F., Lichenysin - a More Efficient Cation Chelator Than Surfactin. Appl. Biochem. Biotech. 2001, 90, 199-210.

(264) Naruse, N.; Tenmyo, O.; Kobaru, S.; Kamei, H.; Miyaki, T.; Konishi, M.; Oki, T., Pumilacidin, a Complex of New Antiviral Antibiotics - Production, Isolation, Chemical Properties, Structure and Biological Activity. J. Antibiot. 1990, 43, 267-280.

(265) Chu, D. T. W.; Plattner, J. J.; Katz, L., New Directions in Antibacterial Research. J. Med. Chem. 1996, 39, 3853-3874.

(266) Li, W. H.; Schlecker, A.; Ma, D. W., Total Synthesis of Antimicrobial and Antitumor Cyclic Depsipeptides. Chem. Comm. 2010, 46, 5403-5420. 
(267) Wu, M. H.; Hancock, R. E. W., Interaction of the Cyclic Antimicrobial Cationic Peptide Bactenecin with the Outer and Cytoplasmic Membrane. J. Biol. Chem. 1999, 274, 29-35.

(268) Ling, L. L.; Schneider, T.; Peoples, A. J.; Spoering, A. L.; Engels, I.; Conlon, B. P.; Mueller, A.; Schaberle, T. F.; Hughes, D. E.; Epstein, S., et al., A New Antibiotic Kills Pathogens without Detectable Resistance. Nature 2015, 517, $455-+$

(269) Zasloff, M., Magainins, a Class of Antimicrobial Peptides from Xenopus Skin Isolation, Characterization of Two Active Forms, and Partial cDNA Sequence of a Precursor. Proc. Nat. Acad. Sci USA 1987, 84, 5449-5453.

(270) Silva, P. I.; Daffre, S.; Bulet, P., Isolation and Characterization of Gomesin, an 18-Residue Cysteine-Rich Defense Peptide from the Spider Acanthoscurria Gomesiana Hemocytes with Sequence Similarities to Horseshoe Crab Antimicrobial Peptides of the Tachyplesin Family. J. Biol. Chem. 2000, 275, 33464-33470.

(271) Hancock, R. E. W.; Lehrer, R., Cationic Peptides: A New Source of Antibiotics. Trends Biotech. 1998, 16, 82-88.

(272) Reddy, K. V. R.; Yedery, R. D.; Aranha, C., Antimicrobial Peptides: Premises and Promises. Int. J. Antimicrob. Agents 2004, 24, 536-547.

(273) Sarges, R.; Witkop, B., Gramicidin A. V. The Structure of Valine- and Isoleucine-Gramicidin A. J. Am. Chem. Soc. 1965, 87, 2011-2020.

(274) Gross, E.; Witkop, B., Gramicidin. IX. Preparation of Gramicidin A, B, and C. Biochemistry 1965, 4, 2495-2501.

(275) Bamberg, E.; Noda, K.; Gross, E.; Lauger, P., Single-Channel Parameters of Gramicidin A, B and C. Biochim. Biophys. Acta 1976, 419, 223-228. 
(276) Burkhart, B. M.; Langs, D. A.; Pangborn, W. A.; Duax, W. L.; Pletnev, V.; Gassman, R. M., Gramicidin D Conformation, Dynamics and Membrane Ion Transport. Biopolymers 1999, 51, 129-144.

(277) Urry, D. W., The Gramicidin-A Transmembrane Channel - A Proposed $\Pi_{(L, D)}$ Helix. Proc. Nat. Acad. Sci USA 1971, 68, 672-676.

(278) Urry, D. W.; Goodall, M. C.; Glickson, J. D.; Mayers, D. F., Gramicidin a Transmembrane Channel - Characteristics of Head-to-Head Dimerized $\Pi_{(L, D)}$ Helices. Proc. Nat. Acad. Sci USA 1971, 68, 1907-1911.

(279) Ketchem, R. R.; Hu, W.; Cross, T. A., High-Resolution Conformation of Gramicidin A in a Lipid Bilayer by Solid-State NMR. Science 1993, 261, 14571460.

(280) Falla, T. J.; Karunaratne, D. N.; Hancock, R. E. W., Mode of Action of the Antimicrobial Peptide Indolicidin. J. Biol. Chem. 1996, 271, 19298-19303. (281) Higashijima, T.; Uzu, S.; Nakajima, T.; Ross, E. M., Mastoparan, a Peptide Toxin from Wasp Venom, Mimics Receptors by Activating Gtp-Binding Regulatory Proteins (G-Proteins). J. Biol. Chem. 1988, 263, 6491-6494. (282) Irazazabal, L. N.; Porto, W. F.; Ribeiro, S. M.; Casale, S.; Humblot, V.; Ladram, A.; Franco, O. L., Selective Amino Acid Substitution Reduces Cytotoxicity of the Antimicrobial Peptide Mastoparan. Biochim. Biophys. ActaBiomembr. 2016, 1858, 2699-2708.

(283) Todokoro, Y.; Yumen, I.; Fukushima, K.; Kang, S. W.; Park, J. S.; Kohno, T.; Wakamatsu, K.; Akutsu, H.; Fujiwara, T., Structure of Tightly MembraneBound Mastoparan-X, a G-Protein-Activating Peptide, Determined by SolidState Nmr. Biophys. J. 2006, 91, 1368-1379. 
(284) Javadpour, M. M.; Juban, M. M.; Lo, W. C. J.; Bishop, S. M.; Alberty, J. B.; Cowell, S. M.; Becker, C. L.; McLaughlin, M. L., De Novo Antimicrobial Peptides with Low Mammalian Cell Toxicity. J. Med. Chem. 1996, 39, 31073113.

(285) Ellerby, H. M.; Arap, W.; Ellerby, L. M.; Kain, R.; Andrusiak, R.; Del Rio, G.; Krajewski, S.; Lombardo, C. R.; Rao, R.; Ruoslahti, E., et al., Anti-Cancer Activity of Targeted Pro-Apoptotic Peptides. Nature Med. 1999, 5, 1032-1038. (286) Jung, D.; Rozek, A.; Okon, M.; Hancock, R. E. W., Structural Transitions as Determinants of the Action of the Calcium-Dependent Antibiotic Daptomycin. Chem. Biol. 2004, 11, 949-957.

(287) Osullivan, J.; McCullough, J. E.; Tymiak, A. A.; Kirsch, D. R.; Trejo, W. H.; Principe, P. A., Lysobactin, a Novel Antibacterial Agent Produced by Lysobacter Sp .1. Taxonomy, Isolation and Partial Characterization. J. Antibiot. 1988, $41,1740-1744$.

(288) Bonner, D. P.; Osullivan, J.; Tanaka, S. K.; Clark, J. M.; Whitney, R. R., Lysobactin, a Novel Antibacterial Agent Produced by Lysobacter Sp. II. Biological Properties. J. Antibiot. 1988, 41, 1745-1751.

(289) Shoji, J.; Hinoo, H.; Matsumoto, K.; Hattori, T.; Yoshida, T.; Matsuura, S.; Kondo, E., Isolation and Characterization of Katanosins A and B. J. Antibiot. 1988, 41, 713-718.

(290) Denning, D. W., Echinocandin Antifungal Drugs. Lancet 2003, 362, 1142-1151.

(291) Debono, M.; Gordee, R. S., Antibiotics That Inhibit Fungal Cell-Wall Development. Annu. Rev. Microbiol. 1994, 48, 471-497.

(292) Morris, M. I.; Villmann, M., Echinocandins in the Management of Invasive Fungal Infections, Part 1. Am. J. Health-Syst. Pharm. 2006, 63, 1693-1703. 
(293) Jestoi, M., Emerging Fusarium-Mycotoxins Fusaproliferin, Beauvericin, Enniatins, and Moniliformin - a Review. Crit. Rev. Food Sci. Nutr. 2008, 48, $21-49$.

(294) Grove, J. F.; Pople, M., The Insecticidal Activity of Beauvericin and the Enniatin Complex. Mycopathologia 1980, 70, 103-105.

(295) Hamill, R. L.; Higgens, C. E.; Boaz, M. E.; Gorman, M., The Structure of Brauvericin, a New Depsipeptide Antibiotic Toxic to Artemia Salina Tetrahedron Lett. 1969, 49.

(296) Sussmuth, R.; Muller, J.; von Dohren, H.; Molnar, I., Fungal Cyclooligomer Depsipeptides: From Classical Biochemistry to Combinatorial Biosynthesis. Nat. Prod. Rep. 2011, 28, 99-124.

(297) Carter, C. S., Neuroendocrine Perspectives on Social Attachment and Love. Psychoneuroendocrinology 1998, 23, 779-818.

(298) Gimpl, G.; Fahrenholz, F., The Oxytocin Receptor System: Structure, Function, and Regulation. Physiol. Rev. 2001, 81, 629-683.

(299) Bartels, A.; Zeki, S., The Neural Correlates of Maternal and Romantic Love. Neuroimage 2004, 21, 1155-1166.

(300) Young, L. J.; Wang, Z. X., The Neurobiology of Pair Bonding. Nature Neuroscience 2004, 7, 1048-1054.

(301) Richardson, D. W.; Robinson, A. G., Drugs Five Years Later - Desmopressin. Ann. Intern. Med. 1985, 103, 228-239.

(302) Wright, J. W.; Harding, J. W., Important Roles for Angiotensin Iii and Iv in the Brain Renin-Angiotensin System. Brain Res. Rev. 1997, 25, 96-124.

(303) Yusuf, S.; Sleight, P.; Pogue, J.; Bosch, J.; Davies, R.; Dagenais, G.; Heart Outcomes Prevent Evaluat, S., Effects of an Angiotensin-Converting-Enzyme 
Inhibitor, Ramipril, on Cardiovascular Events in High-Risk Patients. New Engl. J. Med. 2000, 342, 145-153.

(304) Lewis, E. J.; Hunsicker, L. G.; Bain, R. P.; Rohde, R. D., The Effect of Angiotensin-Converting Enzyme-Inhibition on Diabetic Nephropathy. New Engl. J. Med. 1993, 329, 1456-1462.

(305) Ruiz-Ortega, M.; Lorenzo, O.; Suzuki, Y.; Ruperez, M.; Egido, J., Proinflammatory Actions of Angiotensins. Curr. Opin. Nephrol. Hypertens. 2001, 10, 321-329.

(306) Reichlin, S., Somatostatin .1. New Engl. J. Med. 1983, 309, 1495-1501.

(307) Patel, Y. C., Somatostatin and Its Receptor Family. Front. Neuroendocrinol. 1999, 20, 157-198.

(308) Epelbaum, J., Somatostatin in the Central Nervous System: Physiology and Pathological Modifications. Progr. Neurobiol. 1986, 27, 63-100.

(309) Colao, A.; Ferone, D.; Marzullo, P.; Lombardi, G., Systemic Complications of Acromegaly: Epidemiology, Pathogenesis, and Management. Endocr. Rev. 2004, 25, 102-152.

(310) Valéry, C.; Paternostre, M.; Robert, B.; Gulik-Krzywicki, T.; Narayanan, T.; Dedieu, J. C.; Keller, G.; Torres, M. L.; Cherif-Cheikh, R.; Calvo, P., et al., Biomimetic Organization: Octapeptide Self-Assembly into Nanotubes of Viral Capsid-Like Dimension. Proc. Nat. Acad. Sci USA 2003, 100, 10258-10262.

(311) Valéry, C.; Artzner, F.; Robert, B.; Gulick, T.; Keller, G.; Grabielle-Madelmont, C.; Torres, M. L.; Cherif-Cheik, R.; Paternostre, M., Self-Association Process of a Peptide in Solution: From $\beta$-Sheet Filaments to Large Embedded Nanotubes. Biophys. J. 2004, 86, 2484-2501. 
(312) Tarabout, C.; Roux, S.; Gobeaux, F.; Fay, N.; Pouget, E.; Meriadec, C.; Ligeti, M.; Thomas, D.; Ijsselstijn, M.; Besselievre, F., et al., Control of Peptide Nanotube Diameter by Chemical Modifications of an Aromatic Residue Involved in a Single Close Contact. Proc. Nat. Acad. Sci USA 2011, 108, 76797684.

(313) Hamley, I. W., Peptide Nanotubes. Angew. Chem., Int. Ed. Engl. 2014, 53, $6866-6881$.

(314) Gregory, R. A.; Tracy, H. J.; Harris, J. I.; Runswick, M. J.; Moore, S.; Kenner, G. W.; Ramage, R., Minigastrin - Corrected Structure and Synthesis. HoppeSeylers Z. Phys. Chem. 1979, 360, 73-80.

(315) Tessmar, J. K.; Gopferich, A. M., Matrices and Scaffolds for Protein Delivery in Tissue Engineering. Adv. Drug Del. Rev. 2007, 59, 274-291.

(316) Baird, A.; Schubert, D.; Ling, N.; Guillemin, R., Receptor-Binding and Heparin-Binding Domains of Basic Fibroblast Growth-Factor. Proc. Nat. Acad. Sci USA 1988, 85, 2324-2328.

(317) Gouveia, R. M.; Castelletto, V.; Connon, C. J.; Hamley, I. W., New SelfAssembling Multi-Functional Templates for the Bio-Fabrication and Controlled Self-Release of Live Human Tissues. Tissue Eng. A 2015, 21, 1772-1784.

(318) Gouveia, R. M.; Hamley, I. W.; Connon, C. J., Bio-Fabrication and Physiological Self-Release of Tissue Equivalents Using Smart Peptide Amphiphile Templates. J. Mater. Sci.-Mater. Med. 2015, 26.

(319) Bieth, J.; Spiess, B.; Wermuth, C. G., Synthesis and Analytical Use of a Highly Sensitive and Convenient Substrate of Elastase. Biochem. Med. 1974, 11, 350357. 
(320) Castelletto, V.; Gouveia, R. J.; Connon, C. J.; Hamley, I. W.; Seitsonen, J.;

Ruokolainen, J.; Longo, E.; Siligardi, G., Influence of Elastase on Alanine-Rich Peptide Hydrogels. Biomater. Sci. 2014, 2, 867-874.

(321) Creighton, T. E., Proteins. Structures and Molecular Properties. W.H.Freeman: New York, 1993.

(322) Castelletto, V.; McKendrick, J. M. E.; Hamley , I. W.; Cenker, C.; Olsson, U., Pegylated Amyloid Peptide Nanocontainer Delivery and Release System. Langmuir 2010, 26, 11624-11627.

(323) Dehsorkhi, A.; Hamley , I. W.; Seitsonen, J.; Ruokolainen, J., Tuning SelfAssembled Nanostructures through Enzymatic Degradation of a Peptide Amphiphile. Langmuir 2013, 29, 6665-6672.

(324) Bode, W.; Huber, R., Natural Protein Proteinase-Inhibitors and Their Interaction with Proteinases. Euro. J. Biochem. 1992, 204, 433-451.

(325) Perona, J. J.; Craik, C. S., Structural Basis of Substrate-Specificity in the Serine Proteases. Protein Sci. 1995, 4, 337-360.

(326) Sakiyama, S. E.; Schense, J. C.; Hubbell, J. A., Incorporation of HeparinBinding Peptides into Fibrin Gels Enhances Neurite Extension: An Example of Designer Matrices in Tissue Engineering. FASEB Journal 1999, 13, 2214-2224.

(327) Caplan, M. R.; Schwartzfarb, E. M.; Zhang, S.; Kamm, R. D.; Lauffenburger, D. A., Control of Self-Assembling Oligopeptide Matrix Formation through Systematic Variation of Amino Acid Sequence. Biomaterials 2002, 23, 219227.

(328) Caplan, M. R.; Moore, P. N.; Zhang, S. G.; Kamm, R. D.; Lauffenburger, D. A., Self-Assembly of a $\beta$-Sheet Protein Governed by Relief of Electrostatic 
Repulsion Relative to Van Der Waals Attraction. Biomacromol. 2000, 1, 627631.

(329) Roberts, D.; Rochas, C.; Saiani, A.; Miller, A. F., Effect of Peptide and Guest Charge on the Structural, Mechanical and Release Properties of $\beta$-Sheet Forming Peptides. Langmuir 2012, 28, 16196-206.

(330) Boothroyd, S.; Miller, A. F.; Saiani, A., From Fibres to Networks Using SelfAssembling Peptides. Faraday Discuss. 2013, 166, 195-207.

(331) Saiani, A.; Mohammed, A.; Frielinghaus, H.; Collins, R.; Hodson, N.; Kielty, C. M.; Sherratt, M. J.; Miller, A. F., Self-Assembly and Gelation Properties of $\alpha$ Helix versus $\beta$-Sheet Forming Peptides. Soft Matter 2009, 5, 193-202.

(332) Gao, J.; Tang, C.; Elsawy, M. A.; Smith, A. M.; Miller, A. F.; Saiani, A., Controlling Self-Assembling Peptide Hydrogel Properties through Network Topology. Biomacromol. 2017, 18, 826-834.

(333) Lee, N. R.; Bowerman, C. J.; Nilsson, B. L., Effects of Varied Sequence Pattern on the Self-Assembly of Amphipathic Peptides. Biomacromol. 2013, 14, 32673277.

(334) Marchesan, S.; Waddington, L.; Easton, C. D.; Winkler, D. A.; Goodall, L.; Forsythe, J.; Hartley, P. G., Unzipping the Role of Chirality in Nanoscale SelfAssembly of Tripeptide Hydrogels. Nanoscale 2012, 4, 6752-6760.

(335) Mondal, S.; Adler-Abramovich, L.; Lampel, A.; Bram, Y.; Lipstman, S.; Gazit, E., Formation of Functional Super-Helical Assemblies by Constrained Single Heptad Repeat. Nat. Commun. 2015, 6.

(336) Inouye, H.; Sharma, D.; Goux, W. J.; Kirschner, D. A., Structure of Core Domain of Fibril-Forming PHF/Tau Fragments. Biophys. J. 2006, 90, 17741789. 
(337) Sievers, S. A.; Karanicolas, J.; Chang, H. W.; Zhao, A.; Jiang, L.; Zirafi, O.;

Stevens, J. T.; Munch, J.; Baker, D.; Eisenberg, D., Structure-Based Design of Non-Natural Amino-Acid Inhibitors of Amyloid Fibril Formation. Nature 2011, 475, 96-100.

(338) Cooper, G. J. S.; Willis, A. C.; Clark, A.; Turner, R. C.; Sim, R. B.; Reid, K. B. M., Purification and Characterization of a Peptide from Amyloid-Rich Pancreases of Type-2 Diabetic-Patients. Proc. Nat. Acad. Sci USA 1987, 84, $8628-8632$

(339) Westermark, P.; Wernstedt, C.; Wilander, E.; Hayden, D. W.; Obrien, T. D.; Johnson, K. H., Amyloid Fibrils in Human Insulinoma and Islets of Langerhans of the Diabetic Cat Are Derived from a Neuropeptide-Like Protein Also Present in Normal Islet Cells. Proc. Nat. Acad. Sci USA 1987, 84, 3881-3885.

(340) Hoppener, J. W. M.; Lips, C. J. M., Role of Islet Amyloid in Type 2 Diabetes Mellitus. Int J. Biochem. Cell Biol. 2006, 38, 726-736.

(341) Madine, J.; Jack, E.; Stockley, P. G.; Radford, S. E.; Serpell, L. C.; Middleton, D. A., Structural Insights into the Polymorphism of Amyloid-Like Fibrils Formed by Region 20-29 of Amylin Revealed by Solid-State Nmr and X-Ray Fiber Diffraction. J. Am. Chem. Soc. 2008, 130, 14990-15001.

(342) Tenidis, K.; Waldner, M.; Bernhagen, J.; Fischle, W.; Bergmann, M.; Weber, M.; Merkle, M. L.; Voelter, W.; Brunner, H.; Kapurniotu, A., Identification of a Penta- and Hexapeptide of Islet Amyloid Polypeptide (IAPP) with Amyloidogenic and Cytotoxic Properties. J. Molec. Biol. 2000, 295, 1055-1071.

(343) Wiltzius, J. J. W.; Sievers, S. A.; Sawaya, M. R.; Cascio, D.; Popov, D.; Riekel, C.; Eisenberg, D., Atomic Structure of the Cross- $\beta$ Spine of Islet Amyloid Polypeptide (Amylin). Protein Sci. 2008, 17, 1467-1474. 
(344) Krysmann, M. J.; Castelletto, V.; Kelarakis, A.; Hamley , I. W.; Hule, R. A.; Pochan, D. J., Self-Assembly and Hydrogelation of an Amyloid Peptide Fragment. Biochemistry 2008, 47, 4597-4605.

(345) Hamley, I. W., The Amyloid Beta Peptide: A Chemist's Perspective. Role in Alzheimer's and Fibrillization. Chem. Rev. 2012, 112, 5147-5192.

(346) Tjernberg, L. O.; Callaway, D. J. E.; Tjernberg, A.; Hahne, S.; Lilliehöök, C.; Terenius, L.; Thyberg, J.; Nordstedt, C., A Molecular Model of Alzheimer Amyloid $\beta$-Peptide Fibril Formation. J. Biol. Chem. 1999, 274, 12619-12625. (347) Tjernberg, L. O.; Naslund, J.; Lindqvist, F.; Johansson, J.; Karlstrom, A. R.; Thyberg, J.; Terenius, L.; Nordstedt, C., Arrest of $\beta$-Amyloid Fibril Formation by a Pentapeptide Ligand. J. Biol. Chem. 1996, 271, 8545-8548.

(348) Gazit, E., A Possible Role for $\pi$-Stacking in the Self-Assembly of Amyloid Fibrils. FASEB Journal 2002, 16, 77-83.

(349) Görbitz, C. H., Nanotube Formation by Hydrophobic Dipeptides. Chem. Eur. J. 2001, 7, 5153-5159.

(350) Görbitz, C. H., The Structure of Nanotubes Formed by Diphenylalanine, the Core Recognition Motif of Alzheimer's $\beta$-Amyloid Peptide. Chem. Comm. 2006, 2332-2334.

(351) Reches, M.; Gazit, E., Self-Assembly of Peptide Nanotubes and Amyloid-Like Structures by Charged-Termini-Capped Diphenylalanine Peptide Analogues. Israel J. Chem. 2005, 45, 363-371.

(352) Adler-Abramovich, L.; Gazit, E., The Physical Properties of Supramolecular Peptide Assemblies: From Building Block Association to Technological Applications. Chem. Soc. Rev. 2014, 43, 6881-6893. 
(353) Reches, M.; Gazit, E., Controlled Patterning of Aligned Self-Assembled Peptide Nanotubes. Nature Nanotech. 2006, 1, 195-200.

(354) Zhang, Y.; Kuang, Y.; Gao, Y.; Xu, B., Versatile Small-Molecule Motifs for Self-Assembly in Water and the Formation of Biofunctional Supramolecular Hydrogels. Langmuir 2011, 27, 529-537.

(355) Du, X. W.; Zhou, J.; Shi, J. F.; Xu, B., Supramolecular Hydrogelators and Hydrogels: From Soft Matter to Molecular Biomaterials. Chem. Rev. 2015, 115, $13165-13307$.

(356) Levin, A.; Mason, T. O.; Adler-Abramovich, L.; Buell, A. K.; Meisl, G.;

Galvagnion, C.; Bram, Y.; Stratford, S. A.; Dobson, C. M.; Knowles, T. P. J., et al., Ostwald's Rule of Stages Governs Structural Transitions and Morphology of Dipeptide Supramolecular Polymers. Nat. Commun. 2014, 5.

(357) Adler-Abramovich, L.; Kol, N.; Yanai, I.; Barlam, D.; Shneck, R. Z.; Gazit, E.; Rousso, I., Self-Assembled Organic Nanostructures with Metallic-Like Stiffness. Angew. Chem. Int. Ed. Engl. 2010, 49, 9939-9942.

(358) Amdursky, N.; Molotskii, M.; Gazit, E.; Rosenman, G., Elementary Building Blocks of Self-Assembled Peptide Nanotubes. J. Am. Chem. Soc. 2010, 132, $15632-15636$.

(359) Ryan, D. M.; Anderson, S. B.; Nilsson, B. L., The Influence of Side-Chain Halogenation on the Self-Assembly and Hydrogelation of Fmoc-Phenylalanine Derivatives. Soft Matter 2010, 6, 3220-3231.

(360) Ryan, D. M.; Doran, T. M.; Anderson, S. B.; Nilsson, B. L., Effect of CTerminal Modification on the Self-Assembly and Hydrogelation of Fluorinated Fmoc-Phe Derivatives. Langmuir 2011, 27, 4029-4039. 
(361) Liyanage, W.; Nilsson, B. L., Substituent Effects on the SelfAssembly/Coassembly and Hydrogelation of Phenylalanine Derivatives. Langmuir 2016, 32, 787-799.

(362) Marchesan, S.; Easton, C. D.; Kushkaki, F.; Waddington, L.; Hartley, P. G., Tripeptide Self-Assembled Hydrogels: Unexpected Twists of Chirality. Chem. Comm. 2012, 48, 2195-2197.

(363) Martin, A. D.; Robinson, A. B.; Mason, A. F.; Wojciechowski, J. P.; Thordarson, P., Exceptionally Strong Hydrogels through Self-Assembly of an Indole-Capped Dipeptide. Chem. Comm. 2014, 50, 15541-15544.

(364) Martin, A. D.; Robinson, A. B.; Thordarson, P., Biocompatible Small Peptide Super-Hydrogelators Bearing Carbazole Functionalities. J. Mater. Chem. B 2015, 3, 2277-2280.

(365) Frederix, P. W. J. M.; Scott, G. G.; Abul-Haija, Y. M.; Kalafatovic, D.; Pappas, C. G.; Javid, N.; Hunt, N. T.; Ulijn, R. V.; Tuttle, T., Exploring the Sequence Space for (Tri-) Peptide Self-Assembly to Design and Discover. Nature Chem. 2015, 7, 30-37.

(366) Pencheva, N.; Ivancheva, C.; Dimitrov, E.; Bocheva, A.; Radomirov, R., Dalargin and $\left[\mathrm{Cys}-\left(\mathrm{O}_{2} \mathrm{NH}_{2}\right)\right]^{2}$ Analogs of Enkephalins and Their Selectivity for $\mu$ Opioid Receptors. Gen. Pharmacol. 1995, 26, 799-808.

(367) Mazza, M.; Notman, R.; Anwar, J.; Rodger, A.; Hicks, M.; Parkinson, G.; McCarthy, D.; Daviter, T.; Moger, J.; Garrett, N., et al., Nanofiber-Based Delivery of Therapeutic Peptides to the Brain. ACS Nano 2013, 7, 1016-1026. (368) Chang, M. M.; Leeman, S. E.; Niall, H. D., Amino-Acid Sequence of Substance P. Nature-New Biology 1971, 232, 86-87. 
(369) Hökfelt, T.; Ljungdahl, A.; Terenius, L.; Elde, R.; Nilsson, G., Immunohistochemical Analysis of Peptide Pathways Possibly Related to Pain and Analgesia - Enkephalin and Substance-P. Proc. Nat. Acad. Sci USA 1977, 74, 3081-3085.

(370) Aldrich, J. V.; Senadheera, S. N.; Ross, N. C.; Ganno, M. L.; Eans, S. O.; McLaughlin, J. P., The Macrocyclic Peptide Natural Product CJ-15,208 is Orally Active and Prevents Reinstatement of Extinguished Cocaine-Seeking Behavior. J. Nat. Prod. 2013, 76, 433-438.

(371) Herranz, R., Cholecystokinin Antagonists: Pharmacological and Therapeutic Potential. Med. Res. Rev. 2003, 23, 559-605.

(372) Moran, T. H.; Kinzig, K. P., Gastrointestinal Satiety Signals II. Cholecystokinin. Am. J. Physiol.-Gastroint. Liver Physiol. 2004, 286, G183G188.

(373) Chaudhri, O.; Small, C.; Bloom, S., Gastrointestinal Hormones Regulating Appetite. Philos. Trans. R. Soc. B-Biol. Sci. 2006, 361, 1187-1209.

(374) Pompella, A.; Visvikis, A.; Paolicchi, A.; De Tata, V.; Casini, A. F., The Changing Faces of Glutathione, a Cellular Protagonist. Biochem. Pharmacol. 2003, 66, 1499-1503.

(375) Crush, K. G., Carnosine and Related Substances in Animal Tissues. Comparative Biochem. Physiol. 1970, 34, 3-\&.

(376) Bonfanti, L.; Peretto, P.; De Marchis, S.; Fasolo, A., Carnosine-Related Dipeptides in the Mammalian Brain. Progr. Neurobiol. 1999, 59, 333-353.

(377) Hipkiss, A. R.; Michaelis, J.; Syrris, P., Non-Enzymatic Glycosylation of the Dipeptide L-Carnosine, a Potential Anti-Protein-Cross-Linking Agent. FEBS Lett. 1995, 371, 81-85. 
(378) Brownson, C.; Hipkiss, A. R., Carnosine Reacts with a Glycated Protein. Free Radical Biol. Med. 2000, 28, 1564-1570.

(379) Mehta, A. D.; Seidler, N. W., $\beta$-Alanine Suppresses Heat Deactivation of Lactate Dehydrogenase. J. Enzyme Inhibition Med. Chem. 2005, 20, 199-203.

(380) Hobart, L. J.; Seibel, I.; Yeargans, G. S.; Seidler, N. W., Anti-Crosslinking Properties of Carnosine: Significance of Histidine. Life Sciences 2004, 75, 1379-1389.

(381) McFarland, G. A.; Holliday, R., Retardation of the Senescence of Cultured Human Diploid Fibroblasts by Carnosine. Experiment. Cell Res. 1994, 212, 167-175.

(382) Tischio, J. P.; Patrick, J. E.; Weintraub, H. S.; Chasin, M.; Goldstein, G., Short in vitro Half-Life of Thymopoietin $32-36$ Pentapeptide in Human-Plasma. Int. J. Pept. Protein Res. 1979, 14, 479-484.

(383) Leung, D. Y. M.; Hirsch, R. L.; Schneider, L.; Moody, C.; Takaoka, R.; Li, S. H.; Meyerson, L. A.; Mariam, S. G.; Goldstein, G.; Hanifin, J. M., Thymopentin Therapy Reduces the Clinical Severity of Atopic-Dermatitis. J. Allergy Clin. Immunol. 1990, 85, 927-933.

(384) Singh, V. K.; Biswas, S.; Mathur, K. B.; Haq, W.; Garg, S. K.; Agarwal, S. S., Thymopentin and Splenopentin as Immunomodulators - Current Status. Immunol. Res. 1998, 17, 345-368.

(385) Diblasio, B.; Rossi, F.; Benedetti, E.; Pavone, V.; Pedone, C.; Temussi, P. A.; Zanotti, G.; Tancredi, T., Bioactive Peptides - Solid-State and Solution Conformation of Cyclolinopeptide-A. J. Am. Chem. Soc. 1989, 111, 9089-9098. (386) Wieczorek, Z.; Bengtsson, B.; Trojnar, J.; Siemion, I. Z., Immunosuppressive Activity of Cyclolinopeptide A. Peptide Res. 1991, 4, 275-283. 
(387) Borel, J. F.; Feurer, C.; Gubler, H. U.; Stahelin, H., Biological Effects of Cyclosporin-a - New Antilymphocytic Agent. Agents Actions 1976, 6, 468-475.

(388) http://proteins.gelifesciences.com/knowledge-library/protein-purificationmethods/tagged-protein-purification/ Accessed in 2017.

(389) Vaughan, T. J.; Williams, A. J.; Pritchard, K.; Osbourn, J. K.; Pope, A. R.; Earnshaw, J. C.; McCafferty, J.; Hodits, R. A.; Wilton, J.; Johnson, K. S., Human Antibodies with Sub-Nanomolar Affinities Isolated from a Large NonImmunized Phage Display Library. Nature Biotech. 1996, 14, 309-314.

(390) Schmitt, J.; Hess, H.; Stunnenberg, H. G., Affinity Purification of HistidineTagged Proteins. Mol. Biol. Rep. 1993, 18, 223-230.

(391) Huang, Z. H.; Hwang, P.; Watson, D. S.; Cao, L. M.; Szoka, F. C., TrisNitrilotriacetic Acids of Subnanomolar Affinity toward Hexahistidine Tagged Molecules. Bioconjugate Chemistry 2009, 20, 1667-1672.

(392) Zhao, C. X.; Hellman, L. M.; Zhan, X.; Bowman, W. S.; Whiteheart, S. W.; Fried, M. G., Hexahistidine-Tag-Specific Optical Probes for Analyses of Proteins and Their Interactions. Analyt. Biochem. 2010, 399, 237-245.

(393) Evan, G. I.; Lewis, G. K.; Ramsay, G.; Bishop, J. M., Isolation of MonoclonalAntibodies Specific for Human C-Myc Proto-Oncogene Product. Mol. Cell. Biol. 1985, 5, 3610-3616.

(394) Reddington, S. C.; Howarth, M., Secrets of a Covalent Interaction for Biomaterials and Biotechnology: Spytag and Spycatcher. Curr. Opin. Chem. Biol. 2015, 29, 94-99.

(395) Zakeri, B.; Fierer, J. O.; Celik, E.; Chittock, E. C.; Schwarz-Linek, U.; Moy, V. T.; Howarth, M., Peptide Tag Forming a Rapid Covalent Bond to a Protein, 
through Engineering a Bacterial Adhesin. Proc. Nat. Acad. Sci USA 2012, 109, E690-E697.

(396) Dancker, P.; Low, I.; Hasselbach, W.; Wieland, T., Interaction of Actin with Phalloidin - Polymerization and Stabilization of F-Actin. Biochim. Biophys. Acta 1975, 400, 407-404.

(397) Barden, J. A.; Miki, M.; Hambly, B. D.; Dosremedios, C. G., Localization of the Phalloidin and Nucleotide-Binding Sites on Actin. Euro. J. Biochem. 1987, 162, 583-588.

(398) Stubbe, J.; Kozarich, J. W., Mechanisms of Bleomycin-Induced DNADegradation. Chem. Rev. 1987, 87, 1107-1136.

(399) Simmons, T. L.; Andrianasolo, E.; McPhail, K.; Flatt, P.; Gerwick, W. H., Marine Natural Products as Anticancer Drugs. Molec. Cancer Therapeutics 2005, 4, 333-342.

(400) Donia, M.; Hamann, M. T., Marine Natural Products and Their Potential Applications as Anti-Infective Agents. Lancet Infect. Dis. 2003, 3, 338-348.

(401) Talpir, R.; Benayahu, Y.; Kashman, Y.; Pannell, L.; Schleyer, M., Hemiasterlin and Geodiamolide-Ta - 2 New Cytotoxic Peptides from the Marine Sponge Hemiasterella-Minor (Kirkpatrick). Tetrahedron Lett. 1994, 35, 4453-4456.

(402) DarkinRattray, S. J.; Gurnett, A. M.; Myers, R. W.; Dulski, P. M.; Crumley, T. M.; Allocco, J. J.; Cannova, C.; Meinke, P. T.; Colletti, S. L.; Bednarek, M. A., et al., Apicidin: A Novel Antiprotozoal Agent That Inhibits Parasite Histone Deacetylase. Proc. Nat. Acad. Sci USA 1996, 93, 13143-13147.

(403) Singh, S. B.; Zink, D. L.; Liesch, J. M.; Mosley, R. T.; Dombrowski, A. W.; Bills, G. F.; Darkin-Rattray, S. J.; Schmatz, D. M.; Goetz, M. A., Structure and Chemistry of Apicidins, a Class of Novel Cyclic Tetrapeptides without a 
Terminal Alpha-Keto Epoxide as Inhibitors of Histone Deacetylase with Potent Antiprotozoal Activities. J. Org. Chem. 2002, 67, 815-825.

(404) Closse, A.; Huguenin, R., Isolation and Structural Elucidation of Chlamydocin. Helvetica Chimica Acta 1974, 57, 533-545.

(405) Stahelin, H.; Trippmacher, A., Cytostatic Activity of Chlamydocin, a Rapidly Inactivated Cyclic Tetrapeptide. Eur. J. Cancer 1974, 10, 801-808.

(406) De Schepper, S.; Bruwiere, H.; Verhulst, T.; Steller, U.; Andries, L.; Wouters, W.; Janicot, M.; Arts, J.; Van Heusden, J., Inhibition of Histone Deacetylases by Chlamydocin Induces Apoptosis and Proteasome-Mediated Degradation of Survivin. J. Pharmacol. Exp. Ther. 2003, 304, 881-888.

(407) Ying, Y. C.; Taori, K.; Kim, H.; Hong, J. Y.; Luesch, H., Total Synthesis and Molecular Target of Largazole, a Histone Deacetylase Inhibitor. J. Am. Chem. Soc. 2008, 130, 8455-8459.

(408) Mayer, B. J.; Baltimore, D., Signalling through SH2 and SH3 Domains. Trends Cell Biol. 1993, 3, 8-13.

(409) Schlessinger, J., Sh2/Sh3 Signaling Proteins. Curr. Opin. Genetics Develop. 1994, 4, 25-30.

(410) Kuriyan, J.; Cowburn, D., Modular Peptide Recognition Domains in Eukaryotic Signaling. Ann. Rev. Biophys. Biomolec. Struct. 1997, 26, 259-288.

(411) Mayer, B. J., Sh3 Domains: Complexity in Moderation. J. Cell Sci. 2001, 114, $1253-1263$

(412) Li, S. S. C., Specificity and Versatility of SH3 and Other Proline-Recognition Domains: Structural Basis and Implications for Cellular Signal Transduction. Biochem. J. 2005, 390, 641-653. 
(413) Peczuh, M. W.; Hamilton, A. D., Peptide and Protein Recognition by Designed Molecules. Chem. Rev. 2000, 100, 2479-2493.

(414) Mazur, R. H.; Goldkamp, A. H.; James, P. A.; Schlatter, J. M., Structure-Taste Relationships of Aspartic Acid Amides. J. Med. Chem. 1970, 13, 1217-+.

(415) Butchko, H. H.; Stargel, W. W.; Comer, C. P.; Mayhew, D. A.; Benninger, C.; Blackburn, G. L.; de Sonneville, L. M. J.; Geha, R. S.; Hertelendy, Z.; Koestner, A., et al., Aspartame: Review of Safety. Regul. Toxicol. Pharmacol. 2002, 35, S1-S93.

(416) Lu, Y.; Berry, S. M.; Pfister, T. D., Engineering Novel Metalloproteins: Design of Metal-Binding Sites into Native Protein Scaffolds. Chem. Rev. 2001, 101, 3047-3080.

(417) Sarikaya, M.; Tamerler, C.; Jen, A. K. Y.; Schulten, K.; Baneyx, F., Molecular Biomimetics: Nanotechnology through Biology. Nature Mater. 2003, 2, 577585.

(418) Mejare, M.; Bulow, L., Metal-Binding Proteins and Peptides in Bioremediation and Phytoremediation of Heavy Metals. Trends Biotech. 2001, 19, 67-73.

(419) Garcia, A. M.; Kurbasic, M.; Kralj, S.; Melchionna, M.; Marchesan, S., A Biocatalytic and Thermoreversible Hydrogel from a Histidine-Containing Tripeptide. Chem. Comm. 2017, 53, 8110-8113.

(420) Huang, Z. P.; Guan, S. W.; Wang, Y. G.; Shi, G. N.; Cao, L. N.; Gao, Y. Z.; Dong, Z. Y.; Xu, J. Y.; Luo, Q.; Liu, J. Q., Self-Assembly of Amphiphilic Peptides into Bio-Functionalized Nanotubes: A Novel Hydrolase Model. $J$. Mater. Chem. B 2013, 1, 2297-2304.

(421) Yang, X.; Wang, Y.; Qi, W.; Su, R.; He, Z., Bioorganometallic FerroceneTripeptide Nanoemulsions. Nanoscale 2017, 9, 15323-15331 
(422) Bonfio, C.; Valer, L.; Scintilla, S.; Shah, S.; Evans, D. J.; Jin, L.; Szostak, J. W.; Sasselov, D. D.; Sutherland, J. D.; Mansy, S. S., UV-Light-Driven Prebiotic Synthesis of Iron-Sulfur Clusters. Nature Chem. 2017, DOI:10.1038/nchem.2817

(423) Tena-Solsona, M.; Nanda, J.; Diaz-Oltra, S.; Chotera, A.; Ashkenasy, G.; Escuder, B., Emergent Catalytic Behavior of Self-Assembled Low Molecular Weight Peptide-Based Aggregates and Hydrogels. Chem. Eur. J. 2016, 22, $6687-6694$.

(424) Matson, J. B.; Zha, R. H.; Stupp, S. I., Peptide Self-Assembly for Crafting Functional Biological Materials. Curr. Opin. Solid State Mat. Sci. 2011, 15, $225-235$

(425) Ghadiri, M. R.; Granja, J. R.; Buehler, L. K., Artificial Transmembrane Ion Channels from Self-Assembling Peptide Nanotubes. Nature 1994, 369, 301304.

(426) Tartaglia, G. G.; Vendruscolo, M., The Zyggregator Method for Predicting Protein Aggregation Propensities. Chem. Soc. Rev. 2008, 37, 1395-1401.

(427) Rousseau, F.; Schmykovitz, J.; Serrano, L., Protein Aggregation and Amyloidosis: Confusion of the Kinds? Curr. Opin. Struct. Biol. 2006, 16, 118126.

(428) Fernandez-Escamilla, A. M.; Rousseau, F.; Schymkowitz, J.; Serrano, L., Prediction of Sequence-Dependent and Mutational Effects on the Aggregation of Peptides and Proteins. Nature Biotech. 2004, 22, 1302-1306. 
TOC Entry

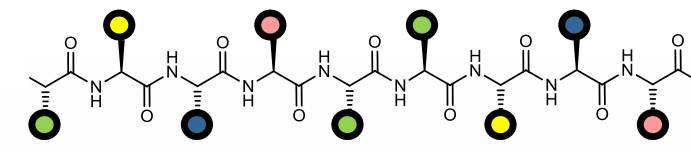

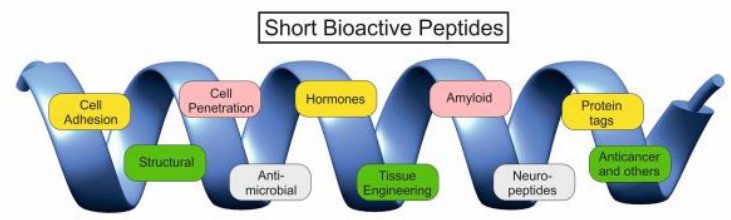

